NBER WORKING PAPER SERIES

\title{
THE INTERNATIONAL PROPAGATION OF ECONOMIC DOWNTURNS THROUGH MULTINATIONAL COMPANIES: THE REAL ECONOMY CHANNEL
}

\author{
Jan Bena \\ Serdar Dinc \\ Isil Erel \\ Working Paper 27873 \\ http://www.nber.org/papers/w27873 \\ NATIONAL BUREAU OF ECONOMIC RESEARCH \\ 1050 Massachusetts Avenue \\ Cambridge, MA 02138 \\ September 2020
}

Bena is with University of British Columbia, Dinc (i.serdar.dinc@gmail.com) is with Rutgers University, and Erel is with Ohio State University, NBER, and ECGI. We would like to thank Sergey Chernenko, Shan Ge, Iftekhar Hasan, Jose Liberti, Robert McDonald, Rene Stulz, Mike Weisbach, as well as seminar participants at the 12th International Conference in Chile, Australian National University, Carnegie Mellon University, Emory University, Erasmus University, European Finance Association Meetings, Koc University, Hong Kong University of Science and Technology, Northwestern University, Ohio State University, Texas A \& M, Tilburg University, University of Amsterdam, University of Hong Kong, University of Rochester, Triple Crown Conference, University of Washington, Villanova University, and York University for their helpful comments. Authors were Fellows of the National Center for the Middle Market at the Fisher College of Business, Ohio State University, and acknowledge the Center's financial support for this research. Bena acknowledges financial support from the Social Sciences and Humanities Research Council (SSHRC) of Canada. Ivan Alfaro and Greg Allen provided excellent research assistance. The usual disclaimer applies. The views expressed herein are those of the authors and do not necessarily reflect the views of the National Bureau of Economic Research.

NBER working papers are circulated for discussion and comment purposes. They have not been peer-reviewed or been subject to the review by the NBER Board of Directors that accompanies official NBER publications.

(C) 2020 by Jan Bena, Serdar Dinc, and Isil Erel. All rights reserved. Short sections of text, not to exceed two paragraphs, may be quoted without explicit permission provided that full credit, including $(\odot$ notice, is given to the source. 
The International Propagation of Economic Downturns Through Multinational Companies:

The Real Economy Channel

Jan Bena, Serdar Dinc, and Isil Erel

NBER Working Paper No. 27873

September 2020

JEL No. F23,G01,G31

\begin{abstract}
We study how non-financial multinational companies propagate economic declines from their subsidiaries located in countries experiencing an economic downturn to subsidiaries in countries not experiencing one. We find that investment is $18 \%$ lower in subsidiaries of these parents relative to the same-industry, same-country subsidiaries of parents that are headquartered in the same parent country but do not have a subsidiary in a country experiencing an economic downturn. The employment growth rate in the affected subsidiaries is zero or negative while it is $1.4 \%$ in the subsidiaries of unaffected parents. The aggregate industry-level sales and employment are also negatively impacted in the countries of the affected subsidiaries.
\end{abstract}

Jan Bena

University of British Columbia

Sauder School of Business

2053 Main Mall

Vancouver, BC

V6T 1 Z2

Canada

jan.bena@sauder.ubc.ca

Serdar Dinc

Department of Finance

Rutgers Business School

1 Washington Park

Newark, NJ 07102

i.serdar.dinc@gmail.com
Isil Erel

Fisher College of Business

Ohio State University

2100 Neil Avenue

Columbus, OH 43210

and NBER

erel@fisher.osu.edu 


\section{Introduction}

The financial sector plays an important role in the propagation of economic downturns across national borders. ${ }^{1}$ While financial firms clearly have a significant global reach, a key role in the overall interconnectedness of the world economy belongs to networks of subsidiaries created by non-financial multinational companies (MNCs). ${ }^{2}$ This paper examines the international propagation of economic downturns by conducting a subsidiary-level analysis of MNCs. Subsidiaries of MNCs are often exposed to economic contractions in the countries of their location. Such local contractions may impact policies and outcomes of the same MNCs' subsidiaries in other countries even when there are no changes in their respective economic conditions. We isolate this propagation channel and estimate the effect of a large local economic downturn that is propagated to destination subsidiaries in terms of real quantities - investment and employment.

The following example illustrates the international propagation of a local economic downturn by the MNCs we study. Consider a hypothetical MNC headquartered in Germany, with subsidiaries located in Spain and Finland. When Spain is experiencing an economic downturn, how are the investment and employment at that German firm's Finnish subsidiary affected? In particular, how do they differ from those of the sameindustry Finnish subsidiary of another German parent firm that does not have a subsidiary in Spain or in another country experiencing an economic downturn that year? This question isolates the common factors at the levels of parent firm's country (Germany in the example), subsidiary country (Finland), and industry in the same year, and therefore

\footnotetext{
${ }^{1}$ See, e.g., Peek and Rosengren (1997, 2000), Khwaja and Mian (2008), Cetorelli and Goldberg (2012), Schnabl (2012), Kalemli-Özcan et al. (2013), Acemoglu, Ozdaglar, and Tahbaz-Salehi (2015).

${ }^{2}$ See Yeaple (2013) and Antràs and Yeaple (2014) for surveys of the literature on MNCs.
} 
focuses on the propagation of downturns from the subsidiary located in a country experiencing an economic downturn to subsidiaries in other countries, as illustrated in Figure 1. In this paper, we study this question using more than thousand MNCs from 16 countries and their more than ten thousand subsidiaries in 23 countries.

A priori, there are reasons that support both higher as well as lower investment and employment growth in the Finnish subsidiary of the German firm that also has a Spanish subsidiary. For example, if the parent firm shifts production from where the economic downturn occurs to a country not experiencing a downturn, the investment and employment growth may be higher in the subsidiary located in the latter country. On the other hand, if the Finnish subsidiary is a supplier to the Spanish subsidiary, and if the latter decreases its investment and employment due to the economic downturn, then the investment and employment in the Finnish subsidiary may also decrease. Furthermore, due to the downturn in the country of one of its subsidiaries, the parent firm may have fewer resources to allocate among its other subsidiaries. Therefore, the parent firm may choose to shrink the investment and employment in other countries. To summarize, whether investment and employment of subsidiaries in countries not experiencing an economic downturn increases or decreases is an empirical question that cannot be answered a priori by theoretical arguments alone.

We show that if a MNC has a foreign subsidiary in a country experiencing a large economic downturn, the investment and employment growth in its foreign subsidiaries located in other countries are lower relative to similar subsidiaries of another MNC that is headquartered in the same country but does not have a subsidiary in a country experiencing an economic downturn. Continuing the example of the hypothetical German parent 
companies above, we show that the Finnish subsidiary of the MNC headquartered in Germany with a subsidiary in Spain during the Spanish economic downturn has lower investment and employment growth that year, relative to the same-industry Finnish subsidiary of another German MNC that does not have any subsidiary in a country with an economic downturn. We do not find any such differences the year before Spain experienced a severe economic downturn. We emphasize that the decreases in investment and employment we document are measured only using the subsidiaries and parent firms in countries not experiencing economic downturns, because we exclude subsidiaries and parent firms in countries with economic downturns from our sample to focus on the propagation effect. In simple terms, our evidence suggests that MNCs transmit economic downturns from source countries to other countries where they operate even when they are headquartered in countries not experiencing an economic downturn.

The economic magnitude of the international propagation of downturns by MNCs we estimate is large. In our sample, annual investment of a subsidiary whose parent firm does not have any subsidiary in a country with an economic downturn is about $3.8 \%$ of its lagged assets on average. Compared to this benchmark, the same country-industry subsidiary of another parent firm headquartered in the same country, but with a subsidiary in a country that experiences an economic downturn, invests about 0.7-0.9 percentage points less on average. In other words, the investment rate is about $18 \%-24 \%$ lower due to the international propagation channel. Similarly, the average employment growth rate in the subsidiaries of unaffected parents is $1.4 \%$. The employment growth rate of the same country-industry subsidiaries of affected parents, however, is lower by about 1.5-2.2 
percentage points. Due to the international propagation channel, the employment thus stagnates or shrinks.

Next we assess whether the international propagation channel by MNCs we document is able to spread local economic problems in a way that the entire destination economies are affected. Specifically, we study aggregate industry-level sales and employment of countries with the presence of subsidiaries of affected parent firms. In the hypothetical example above, if other Finnish firms in the same industry increase their investment and employment to compensate for the declines experienced by the subsidiaries of a parent propagating the Spanish economic downturn, the overall impact of the propagation effect on the aggregate economy will be small. We find, however, that the aggregate country-industry-level sales and employment are both significantly smaller when the subsidiaries that are affected by the international propagation channel account for a larger fraction of the destination country-industry sales or employment. This result suggests that the negative effects of the propagated downturns through MNCs to third countries are not neutralized by other firms. Hence, propagated downturns lead to aggregate level declines of real quantities in these destination countries. More broadly, our results highlight that even if the spread of economic downturns does not occur through the financial system, for example, due to a robust regulatory framework of this sector, such propagation can still occur through ownership networks of MNCs. These findings may be used in designing public policies aimed at preventing local economic crises from escalating to regional or global levels.

The two most likely reasons for why the propagation effect occurs are the presence of supply chain links and internal capital markets within MNCs. We provide an exploratory 
analysis supporting both channels. First, we find that if the subsidiary in a country experiencing an economic downturn operates in a country-industry that is upstream to the other subsidiaries of the same MNC, the magnitude of the propagation effect to the destination subsidiary is reduced. In contrast, the propagation effect is larger if the subsidiary in the country with an economic downturn operates in a downstream industry. Second, we show that economic downturns are transmitted even to subsidiaries in nontradable industries, so the presence of supply chain links is unlikely to be the only reason for the propagation effect to occur. In fact, we confirm that the propagation is stronger for MNCs that are financially constrained. These results together suggest that both key features of MNCs-supply chain relationships and internal capital markets that are centrally coordinated using ownership links — contribute to the propagation effect we identify.

A strand of literature in international economics documents correlation in growth rates between countries, sectors, or firms, see, e.g., Kose and Yin (2001), Forbes (2004), Burstein, Kurz, and Tesar (2008), Johnson (2014), Menno (2014), Zlate (2016), Cravino and Levchenko (2017), and Tweedle (2018). We complement this work by providing microeconomic evidence that one mechanism underlying such international co-movement is the propagation of local downturns across borders via ownership networks of MNCs. This mechanism is distinct from, for example, the international co-movement being driven by global economic downturns hitting multiple economies at the same time or local downturns being transmitted through credit contractions of global banks. Desai, Foley, and Hines (2009) show that U.S. manufacturing companies increase their investment in the U.S. when their foreign investment increases. We, instead, examine the propagation of an economic downturn from one foreign subsidiary of an MNC to another, controlling for the 
economic conditions of the country of the parent company. Our approach is similar to that of Giroud and Mueller (2017), who examine the propagation of housing downturns through employment decisions across localities by firms that operate in multiple regions in the U.S. We differ by studying firms' investment in an international setting focusing on ownership networks of MNCs.

Our paper is also related to the literature on internal capital markets in conglomerates and business groups; recent work includes Gopalan, Nanda, and Seru (2007), Gopalan and Xie (2012), Matvos and Seru (2014), Duchin, Goldberg, and Sosyura (2016), Faccio and O’Brien (2017), and Santioni, Schiantarelli, and Strahan (2017). Our emphasis is to understand the consequences of international geographic dispersion, not business diversification across industries.

Although we study the propagation of economic downturns through ownership linkages within firms but across national borders, another related literature examines the propagation between firms, see, e.g., Hertzel, Li, Officer, and Rodgers (2008), Acemoglu, Carvalho, Ozdaglar, and Tahbaz-Salehi (2012), Kelly, Lustig, and van Nieuwerburgh (2013), Acemoglu, Akcigit, and Kerr (2016), Barrot and Sauvagnat (2016), Wu (2016), Bosker et al. (2018), di Giovanni, Levchenko, and Mejean (2018), Kashiwagi et al. (2018), and Bertrand, Moxnes, and Saito (2019). ${ }^{3}$ Our paper also complements the recent literature on the production linkages within firms, see, e.g., Budd, Konings, and Slaughter (2005) or Boehm, Flaaen, and Pandalai-Nayar (2019).

This paper is organized as follows. The next section describes our identification strategy and data. The third section presents our main results on subsidiary investment,

\footnotetext{
${ }^{3}$ See Carvalho (2014) and Carvalho and Tahbaz-Salehi (2019) for surveys.
} 
followed by a section presenting our results on subsidiary employment growth. In the fifth section, we analyze the robustness of our findings. We present aggregate industry-level results in the sixth section. We provide analyses of possible channels in the seventh section. The conclusion follows.

\section{Identification Strategy, Data Sources, and Sample Description}

\subsection{Test Design}

We examine corporate policies of MNCs' subsidiaries located in countries not experiencing an economic downturn. In our analyses, we control for subsidiary country, industry, year, and parent firm country. The propagation effect we study is identified from the parent firm having another subsidiary in a country experiencing an economic downturn in the same year. A key consideration impacting the efficiency of the estimation in a crosscountry, cross-industry, multi-year, firm-level study like in this paper is the presence of a large heterogeneity in the sample. For example, our sample contains German automotive companies as well as trading companies in Luxembourg. To make our estimates free from functional form assumptions and to avoid the extrapolation of the effects of continuous covariates across different parts of our sample, we adopt matching as our main method of analysis. Our main matching approach directly excludes comparisons where there is lack of common support, that is, it excludes country-industry-year stratas where subsidiaries of affected and non-affected parent firms are not simultaneously present. We also provide various regression analyses and a number of alternative matching techniques as robustness checks.

To explain our main matching approach in detail, consider two multinational parent firms $p_{T}$ and $p_{C}$, both located in the same country $m$ (subscripts $T$ and $C$ are mnemonics for 
'treated' and 'control' while $p$ is a mnemonic for 'parent'). Firm $p_{T}$ has a foreign subsidiary in a country with an economic downturn that year, as defined below, while firm $p_{C}$ does not. We match a subsidiary of $p_{T}$ in industry $i$ and country $n$ to a subsidiary of $p_{C}$ in the same industry $i$ and the same country $n$. Crucially, we allow neither $m$, the country of the parent firms, nor $n$, the country of the subsidiaries that are subject to the comparison, to have an economic downturn that year. In other words, $p_{T}$ 's subsidiary located in a country experiencing an economic downturn that year only leads to $p_{T}$ being designated as 'treated', and this subsidiary itself is not part of the comparison of subsidiaries to measure the propagation effect. As a result, any economic downturn in the parent firms' location, or in the location of their subsidiaries we analyze, is not driving our results.

We use Mahalanobis-metric matching to prepare our comparison sample. In matching estimators terminology, we use exact matching on subsidiary country, subsidiary industry, parent firm country, and year, together with the nearest neighbor matching on selected additional continuous covariates. This is a very stringent matching requirement that allows us to control for many confounding factors. For example, if we did not require the subsidiary country $n$ to be the same for both the treated and control subsidiary, it would be possible that parent $p_{T}$ 's subsidiary is located in a country whose business cycle is relatively more correlated with the country experiencing an economic downturn that has lead $p_{T}$ to be designated as treated in the first place. Additionally, by calling for both treated and control parent firms $p_{T}$ and $p_{C}$ to be in the same country, we control for the possible differential impact of an economic downturn on countries in which the parent firms are located. Similarly, requiring the subsidiary industry and year to be the same for subsidiaries of both treated and control parent firms controls for the possibility of the differential impact 
of an economic downturn on different industries over time. Finally, to increase the precision of sample variance estimates used in the calculation of the Mahalanobis distance measure and to ensure a common support between treatment and control observations, we first eliminate stratas of subsidiary country, subsidiary industry, year, and parent firm country that do not have at least three treatment and three control observations. We then use subsidiary country, subsidiary industry, year, and parent firm country as variables for exact matching, and subsidiary size and parent firm size as continuous variables in the nearest neighbor matching based on the Mahalanobis metric.

Notice that we do not claim that MNCs choose the location of their subsidiaries randomly even though such location decisions were likely made well before our sample period starts. In particular, MNCs may have chosen to locate their subsidiaries in countries less prone to economic downturns, and the MNCs that are particularly vulnerable to economic downturns may have done so to a greater extent. In other words, our treated sample of MNCs that have a subsidiary in a country experiencing an economic downturn may be composed of MNCs that are less vulnerable to economic downturns than other MNCs. However, this potential self-selection biases our analysis against finding any propagation effect of economic downturns in the treated companies. Therefore, to the extent that this self-selection is important, the propagation effect of economic downturns we document may be under-estimated.

To construct our treatment, we use the deviation of a country's real GDP growth rate that year from that country's long-run average. In our baseline specification, we define a country to have an economic downturn if its real GDP growth rate that year is 2 standard deviations or more lower than its own long-run average, where the long-run average and 
standard deviation are both country-specific and calculated over a period that does not overlap with our sample period as described below. Of course, an economic downturn may not exactly take place within a calendar year and may start in the previous year. Since our identification is based on comparison with the previous year, our construction of treatment is conservative and may underestimate the propagation effect. Note also that, based on our definition, whether a country has an economic downturn or not depends only on its own performance and we do not use any potentially subjective list of economic crisis countries.

For a parent firm to be in the treatment group, it has to a) have at least one foreign subsidiary located in a country with an economic downturn; and b) be itself located in a country not experiencing an economic downturn that year. Conversely, for a parent firm to be in the control group, it has to a) have no foreign subsidiary located in a country experiencing an economic downturn; and b) be itself located in a country not experiencing an economic downturn that year. In robustness checks, we vary the threshold used in the economic downturn definition from 2 standard deviations to 1.75 and 2.25 standard deviations below respective country's long-run average real GDP growth. In some tests, we also vary the threshold for control groups to one standard deviation below the country mean or better so that observations that barely miss to be classified as treatment in the main analysis are not considered as control. Finally, in deciding whether a parent firm has a subsidiary in a country experiencing an economic downturn, we use all the subsidiaries and their locations available to us. Specifically, to identify subsidiaries in a country with an economic downturn, we do not restrict on the subsidiaries for which we have accounting data; instead, we consider the full geographical presence available for each parent firm. 


\subsection{Data Sources}

Our parent and subsidiary level data come from the Amadeus/Orbis databases compiled by the Bureau van Dijk (BvD). Amadeus/Orbis contain detailed ownership and financial information on public and private firms worldwide. To construct a panel dataset of multinational companies and their subsidiaries, we use two updates of Orbis that provide cross-sectional data on firms' ownership structures as verified by BvD in November 2008 and July 2012.

We define subsidiaries to be incorporated firms that file their own financial statements and have, in a given year, a single ultimate owner. The ultimate owner is a subsidiary's shareholder that satisfies three criteria. First, the shareholder has to have at least $25.01 \%$ total stake in the subsidiary. The total stake is the sum of the direct and indirect (i.e., via other firms) voting rights the shareholder has in the subsidiary. La Porta et al. (1999) argue that $20 \%$ ownership is sufficient to give control to the largest shareholder, but the data provider uses a $25.01 \%$ threshold and the data do not allow the use of a lower threshold. Most of the subsidiaries in our sample are majority-owned and we also do a robustness check by restricting the sample to those subsidiaries. Second, the subsidiary has no other (identified or unidentified) shareholder with the total stake higher than $25.00 \%$. Third, the ultimate owner is an incorporated firm that is widely held (i.e., it is not controlled by any other ultimate owner) or an individual/family. We define parent MNCs to be ultimate owners that have at least two cross-border subsidiaries, that is, the subsidiary's country of incorporation is different from that of the ultimate owner.

To construct an annual panel of financial data for subsidiaries and their parent multinational firms, we cumulatively combine multiple updates of Amadeus/Orbis in order 
to add back firm-years deleted from more recent updates. This procedure eliminates survivorship bias inherent in BvD databases. ${ }^{4}$ The resulting panel of financial and ownership information gives a unique breadth of coverage in 2008-2012.

We build our sample starting from the overlap of the ownership and financial panels described above and apply the following screens. First, we exclude subsidiaries and parent firms in financial intermediation, as well as in public administration and defense, education, health and social work, and other community, social, and personal service activities (primary two-digit NACE Rev 1.1 codes 65-67, 75, 80, 85, and 90-99). Second, a subsidiary's and parent firm's legal forms need to entail a limited liability structure. Third, we remove very small and young firms, which tend to be noisy, as well as firms that are likely "shell" firms. Specifically, we drop subsidiary-years and parent-years with total assets less than 1 million Euros and subsidiary-years that are within 3 years of the subsidiary's incorporation date. Throughout the paper, we use unconsolidated financial statements for subsidiaries and consolidated financial statements for parent firms. Finally, we require that all financial variables used in our analysis are non-missing.

We obtain country-level annual real GDP data from the World Bank DataBank and calculate the yearly logarithmic growth of real GDP for each country. We first use the data for 1971-2000 to calculate long-term average growth rates and standard deviations for each country separately. We then normalize each country's annual real GDP growth rate for 2008-2012 using the long-term mean and standard deviation calculated for that country from the 1971-2000 period. As mentioned above, in our baseline specification, we define

\footnotetext{
${ }^{4}$ A firm appears in Amadeus/Orbis as long as it files its financial statements, but is typically kept in the database for only four years after its last filing. Also, each update of Amadeus/Orbis contains only the most recent ten years of financial data for each firm (if available).
} 
a country to have an economic downturn in a given year during 2008-2012 if its normalized GDP growth is lower than -2 . We vary this threshold in our robustness checks. Table 1 Panel A presents the countries with economic downturns and the year of their downturn. As the source of treatment, our analysis uses economic downturns from 2008 to 2012 except 2009. Many countries had an economic downturn in 2009 as defined above; therefore, neither the subsidiaries nor the parent firms (and their subsidiaries elsewhere) located in those countries were eligible to be treatment or control in 2009 according to our empirical design.

\subsection{Sample and Summary Statistics}

Table 1 Panel B presents the distribution of the subsidiaries across 23 countries and years in our matched sample. With the exception of Japan, Korea, and Singapore, all of our subsidiaries are from European countries. This is largely because these countries have public disclosure requirements for subsidiaries of foreign parent firms. For example, we have many subsidiaries owned by U.S.-based parents, but do not have any subsidiary located in the U.S. because there is no public disclosure requirement for foreign subsidiaries in the U.S. The number of observations in each country differs, largely based on the country's economic size. Subsidiaries located in France, Germany, Italy, Spain, and UK are well represented. We have observations in every year from 2008 to 2012 except 2009 as explained above. Table 1 Panel C presents the distribution of parent firms across 16 countries and years in the matched sample. These countries tend to be larger, more economically developed, and more geographically widespread, with the U.S., France, Germany, Japan, and Sweden being well represented. 
Table 1 Panel D provides sample statistics on the investment rate and employment growth in the subsidiaries located in countries with economic downturns during the downturn year and, for comparison, the year before the downturn. These are the subsidiaries in crises of only the parents that end up being in our matched sample. The investment as a fraction of lagged assets is $3.2 \%$ in the year before downturn and it drops to $2.8 \%$ in the downturn year, a drop of more than 0.4 percentage points or about $12 \%$. The drop in the employment growth of these subsidiaries is even more substantial: The employment growth that is $1.6 \%$ in the year before the downturn drops to $0.0 \%$. The subsidiaries in downturn countries are excluded from the main analysis below during the downturn years to focus on the international propagation effect of downturns these subsidiaries experience.

Table 2 presents summary statistics for our first outcome-subsidiary investmentand control variables in the matched sample. Panel A contains simple summary statistics that depend on the number of observations, while panel B presents statistics that are independent of the sample size (computed as in Imbens and Rubin (2015)). Panel A reports the sample statistics separately for both treatment and control subsamples, as well as for the full matched sample. The panel also reports the comparison of means and medians across the two subsamples. The results of the comparison of means are based on standard errors robust to clustering at the parent firm level, while the comparison of medians is based on the Wilcoxon test where the cluster robust inference is not available.

Both the average and median size of parent firms and their subsidiaries are slightly larger for the treatment group than for the control group. The mean parent firm cash flow, as measured by the operating profit/loss normalized by the parent firm's lagged total assets, 
is not statistically different between the two groups. These control variables are winsorized at the upper and lower $1 \%$ levels. Finally, subsidiary investment one year before the onset of treatment, normalized by its lagged total assets, has subsample means that are not statistically different across the treatment and control groups.

The statistics reported in Panel A are functions of sample size. Imbens and Rubin (2015) caution against using such statistics in judging covariate balance across the subsamples. Instead, to examine covariate balance, they suggest using mean differences normalized by the standard deviations and variance ratios even though distributions of these statistics are not known and, therefore, exact cutoff points for statistical tests cannot be obtained. In Panel B, we provide these statistics for the 'raw' and matched sample. The raw sample is the sample of treated and non-treated observations before the matching is performed, but already with the constraint that there are at least three possible treated and control observations within each parent firm country by subsidiary country by subsidiary industry by year strata.

The first two columns in Panel B provide differences of means that are standardized by the subsample standard deviations. A well-balanced sample would have these values close to zero. Statistics for the raw sample suggest that there is little balance, especially in the parent firm size with the mean difference over 1.3 times the subsample standard deviation. After matching, the balance improves with the difference of means in parent firm size halved, and all other differences of means being within about 0.2 times their respective standard deviations.

The last two columns in Panel B provide variance ratios for the two subsamples. A well-balanced sample would have these values close to one. Statistics for the raw sample 
suggest that there is little balance for any of the continuous variables except for the lagged subsidiary investment. The matched sample, however, is much better balanced with the subsample variances within $15 \%$ of each other with the exception of subsidiary size, where the matched sample variance ratio is about 1.38 . These statistics suggest that the matched sample is better balanced than the raw sample and is well balanced in most, if not all, dimensions.

Panel $\mathrm{C}$ focuses on the initial comparison of the outcome variable across treatment and control subsamples. We first study the subsidiary investment in the treatment year, that is, the year when the parent firm has another subsidiary in a country experiencing an economic downturn. As the dataset does not provide subsidiary investment explicitly, we construct it as the change in a subsidiary's fixed assets plus depreciation and normalize it with the lagged book value of the subsidiary's assets. To eliminate large acquisitions and divestments, as well as other outliers, we trim the investment rate observations at the $5 \%$ upper and lower tails. The average investment rate in the control subsample is about $3.8 \%$. However, in the treatment subsample, the average investment rate is only $2.9 \%$. This difference is significant at the $5 \%$ level with standard errors robust to clustering at the parent firm level. In other words, investment in the treated subsample is more than $23 \%$ lower than that in the control subsample.

When we study the difference in investment rate from the pre-treatment to the first treatment year, we find this difference to be positive for the control subsample, which indicates an increase in investment from one year to the next. In the treated subsample, however, this difference is negative, which indicates a decrease in investment from the pretreatment to the first treatment year. The mean change in the investment rate for the full 
matched sample is only 0.1 percentage points. The next section provides more precise estimations of the differences in investment rates across the two subsamples.

\section{International Propagation of Economic Downturns by MNCs - Subsidiary Investment}

As we describe above, we construct a matched sample of subsidiaries using the exact matching on the subsidiary country, parent firm country, subsidiary industry (2-digit NACE), and year together with the nearest neighbor matching that we compute using the Mahalanobis metric with the logarithm of subsidiary and parent firm total book assets as covariates. A parent firm is 'treated' if it has a subsidiary in a country experiencing an economic downturn that year with the economic downturn being defined as the real GDP growth of at least two standard deviations less than the country's pre-sample long-term average. Parent firms and subsidiaries located in countries experiencing an economic downturn are excluded from both treatment and control groups that year.

Our first outcome variable is the subsidiary investment, normalized by lagged subsidiary total assets, in the treatment year - the year in which the subsidiary's parent firm has another subsidiary in a country experiencing a large economic downturn. The previous section presented sample statistics that showed a lower investment in the treatment group compared to the control group with the difference being statistically and economically significant. Table 3 Panel A presents the Average Treatment Effect on the Treated (ATET) obtained using the matching estimator with robust standard errors. We adjust the ATET estimate for bias from matching on continuous variables, first, using only the logarithm of lagged subsidiary and parent sizes (first column), and then adding the lagged parent firm profitability and lagged subsidiary investment (second and third column, respectively). The 
estimated ATET ranges from -1.3 to -0.9 percentage points and is always statistically significant at the $1 \%$ level.

The economic magnitude of this difference in the investment rate of treated subsidiaries is also significant. To put the estimated effects into context, recall that the average investment rate is $3.8 \%$ in the control subsample. This means that the investment rate in the treatment subsample, when adjusted for the bias using all four continuous variables, is more than $23 \%$ lower than the average investment rate for the control subsample. We note that more than $56 \%$ of subsidiaries in our sample are in the top $5 \%$ of the size distribution in their respective country-industry pairs. In other words, these subsidiaries are typically the biggest firms. In Section 6, we further confirm that the propagation effects we estimate are economically meaningful because they persist in the aggregate industry-level data.

Matching estimates reported above have standard errors that are robust to heteroscedasticity. Since there may be several subsidiaries of the same parent in our sample, ideally, one would like to have standard errors robust to clustering at the parent firm level to account for any correlation between different subsidiaries of the same parent. ${ }^{5}$ However, treatment and control observations belong to different parent firms and, therefore, by construction, a matched pair of observations is not part of the same such cluster. To obtain cluster-robust standard errors, we estimate the treatment effect using regressions on the matched sample with match pair fixed effects. Put differently, we use

\footnotetext{
${ }^{5}$ It may also be desirable to cluster the standard errors at the parent firm' country by year level, but since we have only 41 or fewer such clusters, we opted for clustering at the parent firm-level in the main analyses. We repeat the main analyses with double clustering at the levels of parent firm and parent firm's country by year and present the results in the Online Appendix as discussed in the Robustness section. The results remain robust to this double clustering.
} 
matching to balance covariates and obtain matched pairs, but we rely on regressions for the estimation of and the inference on the treatment effect.

The results of these regressions are presented in Table 3 Panel B. The variable of interest is the Propagation Treatment Dummy variable, which is equal to one for the treated observation in each match pair, that is, it is equal to one for the subsidiary whose parent firm has another subsidiary in a country experiencing an economic downturn and zero otherwise (we still exclude from the sample subsidiaries and parent firms in countries that have an economic downturn). The coefficient on this dummy variable provides an estimate for ATET. All regressions in Panel B are estimated with match pair fixed effects, and, crucially, the standard errors are robust to clustering at the parent firm level.

The regression in Column 1 estimates ATET using the outcome variable of the matching estimation from Panel A as the dependent variable, and contains no control variables. The estimated coefficient on the treatment dummy variable is negative and statistically significant at the 1\% level. Regressions in Columns 2 and 3 include, as control variables, the continuous variables used in the bias adjustment of the matching estimates in Panel A. With match pair fixed effects, these regressions are comparable to, but not the same as, the bias-adjusted matching estimates. Across the different specifications, the estimated ATET is -0.7 percentage points or lower and it is always statistically significant at the $1 \%$ level. Although slightly smaller than the matching estimates in absolute value, the difference in the investment rate due to treatment is still more than $18 \%$ of the annual average investment rate in the control subsample. With these statistically and economically significant decreases in the subsidiary investment due to the propagation of economic 
downturns by MNCs estimated in different ways, we now move to studying the propagation in terms of employment.

\section{International Propagation of Economic Downturns by MNCs - Subsidiary Employment}

We use the same identification strategy, data sources, and matching procedure to study the effect of having a subsidiary in a country experiencing an economic downturn on employment growth at parent firms' other subsidiaries. Since the availability of subsidiary employment data, on which our employment growth measure is based, is different from that of the investment data, the same matching procedure leads to a slightly different sample than the one described in Table 2. Therefore, we will first briefly discuss the summary statistics and covariate balance in the new matched sample and then present the estimates of the treatment effect on the subsidiary employment growth.

Table 4 Panel A presents summary statistics of our control variables for the treatment and control subsamples. While the matched sample for the employment analysis is about $11 \%$ smaller than that for the investment analysis, the statistics are similar to those reported in Table 2. Table 4 Panel B checks the covariate balance. Covariate balance is also comparable to that in Table 2, perhaps with the exception of the lagged employment growth, which has a higher variance ratio compared to the lagged investment rate variable.

Table 4 Panel $\mathrm{C}$ provides the initial comparison of the employment outcome variables across the treatment and control subsamples. The focus in the previous section was investment, which is a flow variable. Similarly, our focus in this section is a flow variable - employment growth. The dataset provides only the total number of employees in a subsidiary. Using these data, we construct the employment growth rate as $\ln$ (total 
employees $t)-\ln ($ total employeest-1 $)$. The average subsidiary employment growth rate in the control subsample in the event year is about $1.4 \%$, while it is $-0.2 \%$ in the treatment subsample. Although the magnitude of this difference is large, it is not statistically significant at the conventional levels $(\mathrm{p}=0.105)$.

Table 5 Panel A presents the matching estimates of ATET with the employment growth being the outcome variable. The estimate reported in the first column is biasadjusted for the logarithm of the subsidiary and parent firm total assets. The estimated ATET is -1.4 percentage points and it is statistically significant at the $5 \%$ level. When we also use the lagged parent firm profitability and lagged subsidiary employment growth in adjusting for bias due to matching with continuous variables, the ATET estimate becomes -1.5 percentage points and it is again statistically significant at the $5 \%$ level. Given that the average employment growth rate in the control subsample is $1.4 \%$, this is a large difference we estimate for the treated subsidiaries.

Analogous to the subsidiary investment analysis, we also estimate regressions with match pair fixed effects on the matched sample to obtain standard errors robust to clustering at the parent firm level. We present the results in Table 5 Panel B. Estimated coefficients for the Propagation Treatment Dummy variable range between -1.7 and -2.2 percentage points and are always statistically significant at the $1 \%$ level.

Given that the subsidiaries in the control group have an average annual employment growth of $1.4 \%$, as indicated in Table 4 Panel $\mathrm{C}, 1.3$ to 2.2 percentage points lower employment growth at the treatment subsidiaries is a very economically important difference. In fact, employment in the subsidiaries of a parent firm that has a subsidiary in a country experiencing an economic downturn that year does not grow on average; if 
anything, the employment in those subsidiaries shrinks. Notice that any possible decrease in employment we document need not involve massive layoffs. In particular, employment decrease can be achieved by not replacing natural attrition that occurs in employment due to retirement and other reasons. Overall, our evidence suggests that there is a statistically significant and economically meaningful propagation of local economic downturns across national borders through the network of subsidiaries of MNCs that impacts real quantities_-investment and employment.

\section{Robustness}

Natural Disasters. We repeat our analysis replacing severe economic downturns with large natural disasters. ${ }^{6}$ We consider a natural disaster as 'large' if the damage it causes as a fraction of the country's GDP is in the top decile of all the natural disasters during our sample period. We obtained data on natural disasters and the damage they cause from EMDAT, the International Disaster Database maintained by Universite Catholique de Louvain. Similar to the main analysis, a parent is treated if it has a subsidiary in a country experiencing a large natural disaster that year. The control sample is also similarly constructed by using Mahalanobis matching with exact matching for subsidiary country, subsidiary 2-digit industry classification, parent country, and year in addition to (nearest neighbor) matching on parent and subsidiary sizes. Following the main analysis, parents and subsidiaries located in a country experiencing a large natural disaster are excluded from both treatment and control groups in the disaster year.

\footnotetext{
${ }^{6}$ Work that studies the propagation effect of natural disasters includes Barrot and Sauvagnat (2016), Boehm et al. (2019), Carvalho et al. (2020), and Kashiwagi (2018).
} 
We present the results in Table 6. International subsidiaries of parents that have a subsidiary in a disaster country have a 0.5 percentage points lower investment rate that year than the international subsidiaries of the control group. Similarly, the former subsidiaries have a 1.5 to 2.3 percentage points lower employment growth that year. These results show that multinational companies propagate negative effects of natural disasters to their subsidiaries in other countries, confirming our results on the propagation of economic downturns.

Before and After a Downturn. Although our short sample does not allow us to study long dynamics, we still check the propagation in the year before and after a downturn by repeating the regression (2) in Tables 3 and 5 with the outcome variable as of year $\mathrm{t}-1$ and $\mathrm{t}+1$. We exclude subsidiaries (directly or indirectly) exposed to the crisis as of year $\mathrm{t}-1$ when we analyze the outcome variable as of year $\mathrm{t}-1$. This analysis helps us to check for any pre-trends in the data. We report the results in Table 7 . We do not find any propagation effect in the year before the downturn, which suggests the absence of pre-trends. For investment, we find propagation in year $t+1$. The magnitude of the propagation effect is about half of the propagation in the downturn year but it is statistically significant at the $10 \%$ level. We do not find any propagation effect for the employment growth after the downturn year.

For comparison, we repeat the same before-and-after analysis for the subsidiaries that are located in the country of downturn and report the results in Table OA- 8 in the Online Appendix. Unlike the subsidiaries in our main analysis, which are indirectly affected by economic downturns, the subsidiaries in this sample are directly affected by economic downturns and are not part of our propagation analysis. The sample is 
constructed by matching the subsidiaries in downturn countries by exact match of industry, parent country, and year in addition to the Mahalanobis nearest neighbor match based on subsidiary and parent size. Subsidiaries whose parents are themselves located in a country experiencing an economic downturn are excluded from the sample. We present the impact of the economic downturn on both sets of subsidiaries around the economic downturn year in Figure 2. For investment, we observe a ' $\mathrm{V}$ ' shaped effect for both sets of subsidiaries. The effect is more pronounced for directly affected subsidiaries. For employment growth, we still observe a ' $\mathrm{V}$ ' shaped impact for indirectly affected subsidiaries. For directly affected subsidiaries, the impact of the downturn becomes deeper in year $t+1$ and statistically significant at the $10 \%$ level.

The Definition of Economic Downturn. In the main analyses, we define a country to have an economic downturn if its annual real GDP growth rate is at least 2 standard deviations below that country's long-term average. Our treated parent firms have at least one subsidiary in a country experiencing an economic downturn while our control parent firms have none. In Table 8, we present robustness checks with different thresholds for economic downturns, as well as with more stringent requirements for the control sample.

We first change the economic downturn threshold to 1.75 standard deviations below the country's long-term average. We find that our results are similar in magnitude and statistically significant at the $1 \%$ level in all specifications we consider. We then repeat the analyses with the threshold set at 2.25 standard deviations below, and we again find that our results are unchanged.

We also present analyses where we set the threshold for the treated parent firms to be two standard deviations below the countries' long-term averages (as in our main tests), 
but the control parent firms are required to have all their subsidiaries in countries with growth rates higher than one standard deviation below their respective long-term averages. A more stringent requirement for a parent firm to be a control observation may provide a better counterfactual of not experiencing an economic downturn. This definition leads some parent firms to be classified as neither treated nor control and we thus exclude such parent firms from the sample. We again find a lower investment and employment growth in treated subsidiaries that are statistically significant at the 5\% level or better and have comparable magnitudes to our main estimates.

Finally, the effect of an economic downturn may last longer than a year. We repeat the analysis with the restriction that neither treatment, nor control parents have a subsidiary in a country that experienced an economic downturn in the previous year. More specifically, a parent in year $t$ cannot be a treated parent in year $t-1$. We again find our results to be robust at comparable magnitudes and statistical significance levels.

Regression Analysis using the Unbalanced Sample. In our main tests, following Imbens and Rubin (2015), we use matching techniques to construct the sample for the regression analysis, and we use regression specifications with match pair fixed effects to achieve a better balance between the treatment and control groups. In Table 9 Panel A, we present the results of a regression analysis conducted on the full unbalanced sample. This sample has no restrictions on the number of treatment and control observations in any parent firm country-subsidiary country-subsidiary industry-year strata. That is, the sample may not include a treated subsidiary in the same parent firm country, subsidiary country, subsidiary industry, and year combination for every control observation in the sample, and vice versa. Allowing for this heterogeneity increases the sample size more than four times. Instead of 
using match pair fixed effects, regression specifications control for the heterogeneity along these many dimensions by including parent firm country, subsidiary country, subsidiary industry, and year fixed effects, as well as their interactions together with a set of continuous explanatory variables.

The first three regressions reported in Panel A of the Table 9 use subsidiary investment as the dependent variable. The first regression includes fixed effects for parent firm country, subsidiary country, subsidiary industry, and year. The second regression substitutes parent firm country and year interaction fixed effects for parent firm country and year. These interaction fixed effects control for time-varying macroeconomic conditions in parent firm countries and other factors that vary at the country-level. The third regression adds subsidiary country and year interaction effects to control also for the time varying macroeconomic factors in the subsidiary countries. In all three specifications we consider, the estimated propagation effect is negative and statistically significant at the 1\% level. Regressions (4) through (6) in Panel A of Table 9 repeat the same analyses with the employment growth as the dependent variable. We again find a negative and statistically significant propagation effect. We conclude that the international propagation of local economic downturns by MNCs we document in the main analysis is not an artifact of the screens we use to balance the treatment and control subsamples or due to using matching as an estimation technique.

Regression Analysis with Parent Firm Fixed Effects. To control for the parent-firm level time-independent but unobservable factors, we repeat the regressions with parent firm fixed effects. A typical parent has multiple subsidiaries but, since the treatment is still at the parent-year level, the identification is from year-to-year differences. Although we have 
a short panel for this identification strategy to have much statistical power, this analysis may still be informative. In our main analysis, the sample is balanced through matching in a way that a parent treated in a given year is not guaranteed to be included in the control group in another year. For this reason, we again use the unbalanced sample and repeat the regressions in Table 9 Panel B by adding parent firm fixed effects.

We report the results in Table 9 Panel B. The dependent variable in the first three regressions is the investment rate. We find that the coefficient of the propagation indicator is negative and statistically significant in all three specifications we consider. When we repeat the analysis for employment growth, we find that all coefficients are negative but not statistically significant. The international propagation of economic downturns through MNCs is robust to the unobservable, time-independent factors at the parent level for subsidiary investment but not for employment. We do not know the reasons for this asymmetry, but it might be due to the greater stickiness in employment practices in our sample countries; such stickiness may reduce the statistical power in identifying propagation in employment out of yearly changes.

Common Borders. The country experiencing a downturn may share a border with the country where the treated and control subsidiaries are located. There may be concerns that the common borders may lead to unobservable co-movement between the subsidiary located in the country of economic downturn and the treated subsidiary for geographic reasons. Our matching strategy, of course, compares subsidiaries in the same country and industry but it will be helpful to show the robustness of our results to the exclusion of such subsidiaries. We report the results in Table OA-1 Panel A of the Online Appendix. We lose 
about $12-16 \%$ of observations depending on the outcome studied. Yet, the propagation results remain robust at $1 \%$ statistical significance.

Other Geographic Restrictions. Parent firms located in the U.S. account for a large part of the sample. We repeat the main analyses after excluding subsidiaries whose parent firms are located in the U.S. and report the results in Table OA-1 Panel B of the Online Appendix. The sample shrinks substantially, but our results remain statistically significant at similar magnitudes for investment and stronger magnitudes for employment growth. In Panel C, we restrict both subsidiaries and parent firms to be located in the EU. EU firms are subject to a similar regulatory environment, so this subsample may be more homogeneous compared to our main sample. In this subsample, the results become stronger in terms of economic magnitudes and, although the sample size is considerably smaller, the statistical significance weakens only slightly, if at all. In Panel D, we consider only subsidiaries and parent firms located in the Eurozone. These firms not only have a similar regulatory environment but also use the same currency. Since our sample shrinks by more than $80 \%$, we no longer obtain statistically significant results for employment growth. However, the negative effect on investment is more than double compared to that obtained using the main sample and it is statistically significant at the $1 \%$ level. Finally, in Panel E, we restrict the analysis to U.S. parent firms only. We again obtain statistically significant results for subsidiary investment in this smaller sample, but the employment results are significant only in the regression analysis and at the $10 \%$ level. The fact that employment results become statistically weaker in smaller samples may be due to the fact that most of the subsidiaries in our data are located in Europe where the labor markets tend to be more rigid. 
Majority-Owned Subsidiaries. In the main analyses, we require the parent firm to be the largest owner of the subsidiary with at least $25.01 \%$ stake. This definition captures the ability to control a firm by owning less than the majority of shares in many countries. We now repeat the analyses by restricting the subsidiaries to be majority-owned by their parent firms and present these results in Table OA-2 Panel A of the Online Appendix. Although we do not find a lower employment growth in this subsample at the conventional levels of statistical significance, we find a lower investment rate in treated subsidiaries at stronger magnitudes and the $1 \%$ level of statistical significance.

Controlling for Growth Opportunities. It is customary to control for a firm's growth opportunities in an analysis of firm investment or employment growth, typically using a measure of Tobin's q. Very few subsidiaries in our sample are publicly listed so this is not a viable choice at the subsidiary level. Many of the parent firms located outside of U.S. are also private so we do not include Tobin's q as a control variable in our main analyses in order to work with a larger sample. In this subsection, we repeat our main analyses while controlling for the parent firms' growth opportunities using (parent firms') Tobin's q. The results presented in Table OA-2 Panel B of the Online Appendix are of comparable magnitude to those in the main specifications and are statistically significant.

Size-Weighted Estimates. Our sample may include small subsidiaries, so it is important to check that our results are not driven by the behavior of small subsidiaries even though we use a matched sample. In Table OA-2 Panel C of the Online Appendix, we repeat the main regression tests while weighting the observations by their size. Our results remain robust at the $1 \%$ significance level and at comparable magnitudes. 
Randomized Inference. Our sample has multi-level non-nested structure. That is, the original source of the treatment, the economic downturn, varies at the country-year level of affected subsidiaries but our outcomes are measured using information on subsidiaries of the same parent firm located in different countries. This possibly leads to a complex structure of the error term in the matching and regression models we estimate, and might thereby affect our inference. To address this concern, we conduct a randomized inference test.

The randomized inference test we use proceeds in three steps. First, for subsidiaries in our original sample, we randomly reassign GDP growth rates from one country-year to another country-year, that is, we scramble the key part of the data that is used to define our independent variable of interest Propagation Treatment Dummy - we create "fake shocks". Second, with this reshuffled data, we rerun our matching estimations and regressions that are used to produce the baseline results in Tables 3 and 5. We repeat this randomization 1,000 times; each time estimating the ATET (matching) and the coefficient of the Propagation Treatment Dummy (regression). Third, we compute the empirical standard error as the standard deviation of the 1,000 estimated coefficients and empirical p-value as the percentile that the coefficient obtained using our original sample has in the empirical distribution of the 1,000 estimated coefficients.

The results of this analysis are presented in Table OA-2 Panel D of the Online Appendix. Column (1) reports results for subsidiary investment that correspond to specification in column (3) of Table 3 Panel A, and column (2) reports results that corresponds to specification in column (3) of Table 3 Panel B. We show that, in both cases, matching and regression estimation, the empirical standard errors are practically the same 
as those we used to conduct the inference in Table 3 . The empirical p-value is 0.006 in case of matching and 0.031 in case of regression estimation. Column (3) reports results for subsidiary employment growth that corresponds to specification in column (3) of Table 5 Panel A, and column (4) reports results that correspond to specification in column (3) of Table 5 Panel B. In this case, the empirical standard errors are larger compared to those in Table 5, leading to the empirical p-value 0.092 in case of matching and 0.024 in case of regression estimation. To summarize, Table OA-2 Panel D shows that our baseline results continue to be statistically significant at the conventional levels when we account for the subsidiary-country-year nature of the shocks that are affecting simultaneously multiple parent firms.

Alternative Clustering of Standard Errors. Our main regression tests reported in Tables 3 and 5 provide standard errors robust to clustering at the parent firm level. There may be a concern that there is further correlation across the firms operating in the same country as they are subject to the same macroeconomic shocks. Our matching procedure assures that the treated and control subsidiaries are from the same year and both have parents in the same country. Yet, it may still be desirable to check the robustness of our results with standard errors robust to double clustering at the level of parent country-year in addition to parent level despite the fact that there are only 41 or fewer parent firm country-year clusters. The results with this double clustering are presented in the Online Appendix Table OA-2 Panel E. Our results remain robust at the $1 \%$ level of statistical significance.

Difference-in-Differences Estimates. We repeat the main regression analysis using the Difference-in-Differences framework at the subsidiary level around the treatment year. We report the results in the Online Appendix Table OA-3. This analysis helps with controlling 
for the unobservable, time-independent factors at the subsidiary level. As the first regression indicates, our results about the international propagation for the subsidiary investment remain robust at the $1 \%$ level of statistical significance. The international propagation for employment growth in regression (2) is statistically significant with pvalue 0.061 . We also check for pre-trends in regressions (3) and (4) by restricting the sample to those subsidiaries that were eligible to be control observations in our analysis. Specifically, the parents of these subsidiaries were not treated in the previous year and neither the parent, nor the subsidiary is located in a county that experienced a downturn during the two pre-event years. Our sample drops by about a half, but this filter provides a clean sample to check for pre-event trends. We do not find any statistically significant pretrend. These regressions confirm that our main results are robust to controlling for timeindependent unobservable factors at the subsidiary level.

Alternative Outcome Measures. The outcome variables we study in the main analyses are the investment rate and employment growth rate. As a robustness check, we also use the change in the investment rate and change in the employment growth rate and report the results in the Online Appendix Table OA-4. The results remain robust at the 5\% level of statistical significance or better.

Alternative Matching Techniques. We also check the robustness of our results to using alternative matching techniques. In the Online Appendix Table OA-5 Panel A, we construct the matched sample using not only subsidiary and parent firm size measures in computing the Mahalanobis metric, but also the parent firm profitability and lagged investment (lagged employment growth in the employment analysis). We continue to use the exact matching on parent firm country, subsidiary country, subsidiary industry, and 
year. Our results remain robust at the $1 \%$ statistical significance level. In Panel B, we estimate propensity scores and use linearized propensity scores to match treated observations to control observations. Although the propensity scores are estimated using the full sample, we restrict the matches to be in the same parent firm country, subsidiary country, subsidiary industry, and year, as in the main analyses. In other words, we use a linearized propensity score instead of continuous variables in Mahalanobis matching. Our results are robust for both investment and employment growth, usually at the $1 \%$ statistical significance level. Finally, in Panel C, we use Coarsened Exact Matching to study investment. This matching technique only provides a matched sample; the estimates are obtained using a regression analysis on the matched sample. The sample size drops drastically but, with the exception of the most restrictive specification that leads to the smallest sample size, the results remain robust at the 5\% statistical significance level or better.

\section{Impact of the International Propagation on Destination Economies}

We established the existence of the international propagation of large local economic downturns via the network of subsidiaries of MNCs. Specifically, in the prior sections, we showed that if an MNC has a foreign subsidiary in a country with a large economic downturn, the investment and employment growth in its foreign subsidiaries located in other countries are lower relative to similar subsidiaries of another MNC that is headquartered in the same country but does not have a subsidiary in a country with an economic downturn. Although the propagation effects we estimate are large for the recipient subsidiaries of the affected MNCs and these subsidiaries are typically very large firms, the overall impact of the international propagation on the recipient subsidiaries' 
countries can still be small. This may be because other firms, for example, local standalone firms operating in the same country and industry as the recipient subsidiaries, increase their investment and employment to compensate for the declines due to the propagation.

To assess whether the international propagation channel by MNCs we document is able to spread a local economic downturn so that the entire destination economies are affected, we study aggregate industry-level sales and employment of countries with the presence of recipient subsidiaries. Specifically, we ask whether the aggregate countryindustry-level sales and employment vary with the exposure to the international propagation effect. To measure this exposure, we construct the Propagation Share variable as follows. For each country $c$ that does not have an economic downturn in year $t$ and industry $i$, we identify subsidiaries of treated parent firms. Similar to our main analyses, a parent firm is treated in year $t$ if it is headquartered in a country without an economic downturn but has a subsidiary in a country that has an economic downturn that year. We then find the share of these subsidiaries in total sales (or employment) in country $c$ and industry $i$ as of year $t-1$. This gives the value of Propagation Share for country $c$, industry $i$, and year $t$.

To construct the sample for these analyses, we use census-based industry-level annual data for sales and employment from Eurostat's Structural Business Statistics in the 2008-2012 period. $^{7}$ The sales and employment data for subsidiaries are from BvD's Amadeus/Orbis datasets. We define industry at the NACE 3-digit level throughout these analyses. Table 10 Panel A presents the sample statistics. The mean of Propagation Share is $4.6 \%$ and $3.0 \%$ when computed using sales and employment, respectively. On average

\footnotetext{
${ }^{7}$ We use sales because Eurostat does not provide information that allows constructing investment rates.
} 
in any given year, a country-industry cell in our sample has sales of 1,389 million Euros and 8,095 employees. Using this country-industry panel sample, we estimate regression

$$
y_{i c, t}=\beta \cdot \text { Transmission Share }_{i c, t}+\delta X_{i c, t-1}+\theta_{c, t}+\lambda_{i, t}+\epsilon_{i c, t},
$$

where $y_{i c, t}$ is the logarithm of total sales or employment in country $c$, industry $i$, and year $t$, Propagation Share is as defined above, $X_{i c, t-1}$ are control variables, $\theta_{c, t}$ denote country-year interaction fixed effects, and $\lambda_{i, t}$ denote industry-year interaction fixed effects.

Table 10 Panel B presents the estimates of regression (1). The dependent variable in Columns (1)-(4) is the logarithm of the country-industry level sales. Column (1) has Propagation Share variable together with country, industry, and year fixed effects, while Columns (2)-(4) use country-year and industry-year interaction fixed effects to control for country- and industry-specific macroeconomic factors and business cycle fluctuations. Column (3) adds the logarithm of the sum of lagged sales of all foreign subsidiaries located in each country-industry pair to control for possible effects due to the differential presence of MNCs. To control for the direct spillover of economic downturns from countries of subsidiaries' parent firms, Column (4) further adds the sum of lagged sales of foreign subsidiaries whose parent firms are headquartered in countries with an economic downturn in a given year as a fraction of the country-industry level sales. We cluster standard errors at the country-industry level. ${ }^{8}$

In all specifications we consider, Propagation Share has a negative coefficient that is statistically significant at the $5 \%$ level or better. This result shows that the aggregate country-industry-level sales are significantly smaller when the subsidiaries that are

\footnotetext{
${ }^{8}$ It may also be desirable to cluster the standard errors both at the country and industry level, but since we have only 25 country clusters, we opted for clustering at the country-industry level. We repeat the Table 9 Panel B analyses with double clustering at the levels of countries and industries and present the results in the Online Appendix Table OA- 6 . The results remain robust to this double clustering.
} 
adversely affected through the international propagation channel account for a larger fraction of the destination country-industry sales. This finding suggests that other firms operating in the same country-industry do not replace, at least not within the same year, the adverse effects of large economic downturns propagated to the destination countries via the network of MNCs' subsidiaries.

Columns (5)-(8) repeat the first four regressions with employment replacing sales in the definitions of the dependent variable, Propagation Share, and control variables. Propagation Share again has a negative coefficient that is statistically significant at the $1 \%$ level in all specifications. This result suggests that hiring by other firms does not replace the employment reduction occurring in MNCs' subsidiaries that are adversely affected through the international propagation channel from other countries.

In terms of economic magnitude, the estimate in Column (2) implies that a onepercentage-point increase in Propagation Share, a plausible comparative static exercise given that the mean (median) of Propagation Share is $4.6 \%(0 \%)$ and its standard deviation is $12.9 \%$ in our sample, leads to $0.37 \%$ decrease of total industry sales. Analogously, the estimate in Column (6) implies an employment reduction of $0.46 \%$. Since the average growth of total industry sales and employment of country-industries in our sample is, respectively, $5.1 \%$ and $-1.0 \%$, our findings suggest that the international propagation has a large negative impact on industries in destination countries.

Finally, in Table 10 Panel $\mathrm{C}$, we do a placebo analysis by including the leads and lags of Propagation Share variable. Specifically, we keep the set of subsidiaries used in the construction of Propagation Share unchanged, and we use the sum of the leads and lags of sales (employment) of these same subsidiaries divided by the total country-industry 
sales (employment) measured as of $t-1$ to avoid simultaneity. Since parent firms of these subsidiaries typically do not have other subsidiaries in countries with economic downturns in years other than $t$, we should estimate insignificant coefficients on the leads and lags of Propagation Share if this variable is capturing the international propagation effect by MNCs. Results in Panel C show that leads and lags of Propagation Share do not have significant coefficients which supports the interpretation that Propagation Share is capturing the international propagation effect.

Our country-industry level analyses show that the international propagation of economic downturns by MNCs we document adversely affects industry sales and employment in destination countries. These findings suggest that this international propagation channel is able to spread a local economic downturn so that the entire destination economies are affected with material aggregate consequences for the real economy.

\section{Channels of the International Propagation}

Our analyses so far show the propagation of economic downturns from one country to another that are occurring via subsidiary networks of MNCs, but they do not provide insights about reasons for why the propagation effect occurs. Prior literature highlights the presence of supply chain links between subsidiaries and internal capital markets that are centrally coordinated from headquarters to be key features of MNCs. In this section, we provide evidence that is consistent with both these features contributing to the international propagation by MNCs we document. ${ }^{9}$

\footnotetext{
${ }^{9}$ These reasons for the propagation to occur are not mutually exclusive and there may also be other channels.
} 


\subsection{Supply Chain Links}

The most relevant supply chain links contributing to the international propagation effect would presumably be those between the subsidiary located in the country experiencing an economic downturn, henceforth a 'affected subsidiary', and the same MNC's other subsidiaries. If, for example, the affected subsidiary is downstream from another subsidiary, the reduced demand by the former may force the latter to reduce its investment and employment. Similarly, if the affected subsidiary is in the upstream, the disruptions in the former due to the downturn may be reflected in the latter's investment and employment. In these cases, the supply chain relationships make the propagation effect stronger. Conversely, the customer subsidiaries in countries without an economic downturn may shield the affected subsidiary from any negative effects, and, as a result, the propagation effect may be weaker.

One would ideally use data on bilateral shipments for this type of analysis. Unfortunately, we do not have these data, so we use input-output tables at the countryindustry level to construct a proxy for the supply chain relationship between the affected subsidiary and the other subsidiaries of the same parent firm. These data report the input of say, German steel industry in French auto industry. In other words, unlike a typical within-country input-output table that reports the share of steel input in auto industry, we can condition the input-output relationship to the origin and destination countries. Naturally, these are only proxies for supply chain relationships within a multinational company. However, the variation in the input-output relationships at the aggregate level is likely to reflect the underlying relative comparative advantages of industry-country pairs. The aggregate input-output data can thus still be used to capture the importance of supply 
chain links for the propagation effect and such data can also be considered more likely to be exogenous.

We use the international input-output table for 2007 published by OECD to construct our supply chain measures. The dataset provides the dollar amount of inputs from a country-industry pair used in the output by another country-industry pair. That is, the advantage of this dataset is that it provides input-output relationship from industry $i$ located in country $c$ to industry $j$ located in country $d$. For each treated parent firm, we use these data to construct measures for the propensity to have upstream and downstream supply chain relationship between the affected subsidiary and the firm's other subsidiaries. ${ }^{10} 11$ The measures are zero for subsidiaries of control parent firms, which do not have any affected subsidiary by definition.

We present the results in Table 11. The estimation approach is the same as in Table 3 Panel B. The dependent variable is subsidiary investment normalized by lagged subsidiary assets and each regression includes match pair fixed effects. The standard errors

\footnotetext{
${ }^{10}$ More specifically, we first calculate the direct requirement matrix for one dollar of output for all countryindustry pairs. We then calculate the total requirement matrix by obtaining the 'Leontief inverse' that incorporates indirect supply chain effects. The elements of this matrix give the total requirement for the dollar amount of products by supplier industry $i$ located in country $c$ to produce a dollar's worth of production by the customer industry $j$ located in country $d$, see Miller and Blair (2009, ch. 2). For our upstream measure, we use the entry in this matrix with the country-industry of the affected subsidiary as the supplier countryindustry and the country-industry pairs of the same parent firm's other subsidiaries as customer countryindustry pairs, and vice versa for our downstream measure. Both measures are very skewed with most of the values being close to zero. We therefore use the indicator for those subsidiaries in the top decile of our sample distributions instead of a continuous measure as a proxy for the affected subsidiary to be in the upstream or downstream. The top decile cutoffs in the investment sample are $0.7 \%$ for the upstream measure and $3.0 \%$ for the downstream measure.

${ }^{11}$ Note that these measures cannot be constructed through the interaction of simple indicator variables for subsidiary $i$ in the regression sample. To see this, it might be worthwhile to revisit the example of German MNC with subsidiaries in Spain and Finland as discussed in the Introduction. Consider an indicator variable for the Finnish subsidiary to have a supply chain relationship with another subsidiary of the same parent and another indicator variable for that German parent to have a subsidiary affected by an economic downturn. Both of those indicators would be one for the Finnish subsidiary even if the Finnish subsidiary had a supply chain relationship with a subsidiary, say, in France, which is not experiencing a downturn. Instead, our supply chain measures require the Finnish subsidiary to have a supply chain relationship with the Spanish subsidiary, which is located in the country experiencing an economic downturn.
} 
are clustered at the parent firm level. The first regression includes Propagation Treatment indicator variable and variable Affected Sub in Up Stream, which is a binary indicator that takes the value of one if the strength of the supply chain relationship between the affected subsidiary as a supplier and the same parent firm's other subsidiary as a customer is in the top decile in our sample. Propagation Treatment continues to have a negative and statistically significant coefficient at the 1\% level but Affected Sub in Up Stream has a positive coefficient that is statistically significant at the $10 \%$ level. The combined effect reported in row ' $(a)+(b)$ ' is still negative but no longer significant. This suggests that the propagation effect we find may be weaker or non-existent when the subsidiaries in countries without an economic downturn are customers to the subsidiary in a country experiencing an economic downturn. The marginal effect of Affected Sub in Up Stream is no longer statistically significantly different from zero when controls are added in Column (2) and the combined effect remains insignificant.

Regressions in Columns (3) and (4) focus on variable Affected Sub in Down Stream, which is constructed using the same procedure except that the affected subsidiary is a customer and the same parent firm's other subsidiary is a supplier. In Column (3), Affected Sub in Down Stream has a negative but insignificant coefficient $(\mathrm{p}=0.116)$, which becomes statistically significant ( $\mathrm{p}=0.062)$ when the controls are added in Column (4). Propagation Share continues to have a negative and statistically significant coefficient at the $1 \%$ level. The combined effect is also negative and statistically significant at the $1 \%$ level. We obtain similar results using the last two regressions in Table 10, which include both supply chain indicators together. 
The results with subsidiary investment suggest that the international propagation effect via MNCs we find may be stronger when the subsidiary in a country experiencing an economic downturn is a customer to other subsidiaries of the same parent firm and weaker when it is a supplier. These findings suggest that the effect may depend on the supply chain linkages between the subsidiaries. ${ }^{12}$

\subsection{Internal Capital Markets}

If parent firms cannot obtain external financing due to financial constraints to sustain the optimal level of investment and employment at each subsidiary, an economic downturn to one subsidiary may be transmitted to another through working of internal capital markets. To investigate whether internal capital markets can be a channel through which the propagation of an economic downturn takes place in MNCs, one would ideally use data on financial transfers from parent firms to subsidiaries (and vice versa), as well as transfers occurring directly among subsidiaries. Unfortunately, we do not have such data. Instead, we use two different approaches. First, we check whether the propagation effect we find is stronger in a sample of parent firms that can be considered as financially constrained according to the measures in the corporate finance literature. Then, we study whether there is still the international propagation of economic downturns to subsidiaries in non-tradable industries. For these subsidiaries, an important potential reason for propagation, namely, trade along within-firm supply chain links, is likely to be absent.

The firms in our sample are unlikely to be financially constrained according to the traditional measures. Figure OA-1 Panel A in Online Appendix compare the total sales of

\footnotetext{
12 We do not find any coherent and significant relationship between our supply chain measures and employment growth so we omit them.
} 
the U.S. parents in our sample and the U.S. Compustat firms in 2004-2006, just before our sample period and the financial crisis. The firms in our sample are larger. Panel B shows that the U.S. parents in our sample hold more cash relative to their assets than U.S. Compustat firms. Finally, Panels C and D compare the financial constraint index due to Whited and $\mathrm{Wu}$ (2006) for the U.S. parents in our sample with Compustat firms during the same time period; the firms in our sample have much higher index value.

With this challenge in mind, we proceed to study whether the propagation effect we find is stronger in firms that can be considered as financially constrained. The first measure we use is the Whited-Wu index. Since this measure was developed for U.S. publicly-traded firms, we focus on U.S. parents in our sample. The literature often considers the bottom $30 \%$ or $40 \%$ of the U.S. Compustat firms according to this measure as financially constrained. Very few firms in our sample fall below that threshold so we use the cutoff of 50\% in our analysis, which is reported in Table 12 Panel A. Our focus is the interaction effect of our treatment indicator with $W W 50$, which takes the value of one for firms that have lower Whited-Wu index value than the median value for Compustat firms in 2004-2006, just before our sample period. A negative and statistically significant coefficient for this interaction term suggests that the propagation effect we find is stronger in financially constrained firms.

The first regression in Table 12 Panel A repeats the main regression for the matched sample from Table 3 with the investment rate as the dependent variable. The only difference is that $W W 50$ is also used in the matching to incorporate the fact that financially constrained parents may be different from the unconstrained parents in multiple dimensions. This way the subsidiary of a financially constrained treated parent is matched 
to a subsidiary of a financially constrained parent from the pool of control observations. Other exact and continuous matching variables remain the same. The interaction of treatment indicator and $W W 50$ has a negative and significant coefficient, which indicates that the propagation effect we find is indeed stronger for the financially constrained parents.

Since we have few financially constrained parents, exact matching on $W W 50$ may be restrictive so we drop it from matching variables but, instead, include it in the regression control variables together with its interaction with all other control variables. That way, the treatment indicator is not the only variable whose coefficient is allowed to be different for financially constrained parents. The interaction of treatment indicator and $W W 50$ again has a negative and significant coefficient.

In columns (3) and (4), we repeat the first two regressions with the employment growth as the dependent variable. In both cases, the interaction term has a negative coefficient, which is statistically significant in one of them. Although the number of firms that have low Whited-Wu index values in our sample is not large enough to allow a subsample analysis and the power of these tests may be limited, these results suggest that the propagation effect we find is stronger for firms that are financially constrained as measured by the Whited-Wu index.

We repeat this analysis using another indicator of financially constrained parents, namely, whether the parent firms have credit ratings. Since few countries outside the U.S. have developed bond markets, we restrict our analysis to U.S. parents. The focus is now on the coefficient of the interaction of treated indicator and the No-Rating, which takes the value of one if the parent has no credit rating. We report the results in Table 12 Panel B. In 
the first two regressions where the dependent variable is the investment rate, the interaction term has a negative but statistically insignificant coefficient. In columns (3) and (4), where the dependent variable is the employment growth, this interaction terms has a negative and statistically significant coefficient. We also do a subsample analysis and report the results in Table OA-7 of the Online Appendix. The propagation treatment effect is negative and significant in both matching and regression analysis for both investment rate and employment growth in the subsample of unrated firms. For rated firms, the propagation effect is negative but rarely significant. These results suggest that internal capital markets play an important role in the international propagation of economic downturns.

We also study the role of internal capital markets in the subsample of firms, for which the supply chain channel is absent, namely the firms that operate in non-tradeable products. If we still find propagation through these firms, the propagation channel is likely to be internal capital markets. We use two different definitions for the industries of nontradable products. Our broad definition includes all non-manufacturing industries. Our second, much narrower definition includes construction (nace=45), retail trade (52), hotels and restaurants (55), and real estate (70). The advantage of the narrower definition is that the products of these industries are very unlikely to be traded internationally. The disadvantage is that the resulting sample is less than $5 \%$ of the original sample for the investment analyses and less than 3\% for the employment growth analyses; the statistical power of analyses using these subsamples is thus much lower.

Table 13 Panel A presents the results for the subsidiaries in non-tradable industries according to the broad definition. We find that the subsidiaries of treated parent firms have both lower investment and employment growth. In Panel B, we present the results for the 
subsidiaries in non-tradable industries according to the narrow definition. We again find a lower investment for these subsidiaries at the 5 or $10 \%$ statistical significance; the estimated negative effects are not statistically significant for the employment growth in this much smaller sample. The finding that there is international propagation of large local economic downturns to subsidiaries that are very unlikely to have trade links with other subsidiaries of the same MNC suggests that internal capital markets are contributing to this propagation. Overall, we conclude that both supply chain links between subsidiaries and, especially, internal capital markets are likely contributing to the international propagation of downturns by MNCs we find.

\section{Conclusion}

In this paper, we study how non-financial multinational companies propagate large economic downturns from one country to another through the network of their subsidiaries. We focus on MNCs whose parent firms are not experiencing an economic downturn directly but have a subsidiary in a country with a large economic downturn. The investment and employment growth of other subsidiaries of such affected parent firms are significantly lower compared to the same country-industry subsidiaries of parent firms that do not have any subsidiary exposed to an economic downturn. This methodology allows us to identify how economic downturns are spread across borders in a way different from other known channels that lead to international co-movement such as global economic crises that affect multiple economies at the same time or local downturns that are propagated through the financial sector. We also show that the international propagation channel by MNCs we identify is able to spread local economic downturns so that the sales and employment of entire destination economies are affected. These findings may be used in designing public 
policies aimed at preventing local economic crises from escalating to regional or global levels.

An interesting question is whether MNCs also propagate economic upturns internationally. Our framework allows such a study but there are few MNCs that are positively treated during our sample period of 2008-2012 without also being negatively treated in the same year. Many of the positive treatment cases also come right after a major downturn during this sample period so they may be subject to different dynamics. Hence, we leave the study of this important and interesting question to future work. 


\section{References}

Acemoglu, Daron, Ufuk Akcigit, and William Kerr. "Networks and the macroeconomy: An empirical exploration." NBER Macroeconomics Annual 30, no. 1 (2016): 273335

Acemoglu, Daron, Vasco M. Carvalho, Asuman Ozdaglar, and Alireza Tahbaz-Salehi, 2012, The Network Origins of Aggregate Fluctuations, Econometrica 80(5), 19772016.

Acemoglu, Daron, Asuman Ozdaglar, and Alireza Tahbaz-Salehi, 2015, Systemic Risk and Stability in Financial Networks, American Economic Review 105, 564-608.

Alfaro, Laura, and Maggie Xiaoyang Chen, 2012, Surviving the Global Financial Crisis: Foreign Ownership and Establishment Performance, American Economic Journal: Economic Policy 4(3), 30-55.

Antrás, Pol, and Stephen R. Yeaple, 2014, Multinational Firms and the Structure of International Trade, Handbook of International Economics 4, 55-130.

Barrot, Jean-Noel, and Julien Sauvagnat, 2016, Input Specificity and the Propagation of Idiosyncratic Shocks in Production Networks, The Quarterly Journal of Economics 131(3), 1543-1592.

Bernard, Andrew B., Andreas Moxnes, and Yukiko U. Saito. "Production networks, geography, and firm performance." Journal of Political Economy 127, no. 2 (2019): 639-688.

Bosker, Maarten, Thanh Nam Le, and Bastian Westbrock, 2018, The propagation of a trade cost shock in the global production network, working paper.

Boehm, Christoph E., Aaron Flaaen, and Nitya Pandalai-Nayar, 2019, "Input linkages and the transmission of shocks: firm-level evidence from the 2011 Tōhoku earthquake." Review of Economics and Statistics 101, no. 1 (2019): 60-75.

Burstein, Arial, Christopher Kurz, and Linda Tesar, 2008, Trade, Production Sharing, and the International Propagation of Business Cycles, Journal of Monetary Economics 55(4), 775-795.

Carvalho, Vasco M., 2014, From Micro to Macro via Production Networks, The Journal of Economic Perspectives 28(4), 23-47.

Carvalho, Vasco M., Makoto Nirei, Yukiko U. Saito, and Alireza Tahbaz-Salehi, 2020. "Supply Chain Disruptions: Evidence From The Great East Japan Earthquake," Working paper.

Carvalho, Vasco M., and Alireza Tahbaz-Salehi. "Production networks: A primer." Annual Review of Economics 11 (2019): 635-663.

Cetorelli, Nicola and Linda S. Goldberg, 2012, Banking Globalization and Monetary Propagation, Journal of Finance 67, 1811-1843.

Cravino, Javier, and Andrei A. Levchenko, 2016, Cravino, Javier, and Andrei A. Levchenko. "Multinational firms and international business cycle propagation." The Quarterly Journal of Economics 132, no. 2 (2016): 921-962.

Desai, Mihir A., C. Fritz Foley, and Kristin J. Forbes, 2008, Financial Constraints and Growth: Multinational and Local Firm Responses to Currency Depreciations, Review of Financial Studies 21, 2857-2888.

Desai, Mihir A., C. Fritz Foley, and James R. Hines, 2009, Domestic Effects of the Foreign Activities of US Multinationals, American Economic Journal: Economic Policy 1, 
181-203.

di Giovanni, Julian, Andrei A. Levchenko, and Isabelle Mejean. "The micro origins of international business-cycle comovement." American Economic Review 108, no. 1 (2018): 82-108.

Duchin, Ran, Amir Goldberg, and Denis Sosyura, 2016. "Spillovers inside conglomerates: incentives and capital." The Review of Financial Studies 30, no. 5 (2016): 16961743.

Erel, Isil, Yeejin Jang, and Michael S. Weisbach, 2015, Do Acquisitions Relieve Target Firms' Financial Constraints? Journal of Finance 70, 289-328.

Erel, Isil and Jang, Yeejin and Weisbach, Michael S., The Corporate Finance of Multinational Firms, 2020, to appear in "Multinational Corporations in a Changing Global Economy, ” Brookings Institution.

Faccio, Mara, and William O'Brien, 2017, Business Groups and Employment, working paper.

Forbes, Kristin J., 2004. The Asian flu and Russian virus: the international propagation of crises in firm-level data. Journal of International Economics, 63(1), pp.59-92.

Giroud, X., and H. Mueller, 2017, "Redistribution of Local Labor Market Shocks through Firms' Internal Networks," working paper.

Hertzel, Michael G., Zhi Li, Micah S. Officer, and Kimberly J. Rodgers, 2008, Inter-firm Linkages and the Wealth Effects of Financial Distress Along the Supply Chain, Journal of Financial Economics 87, 374-387.

Imbens, Guido and Jeffrey Wooldridge, 2009, Recent Developments in the Econometrics of Program Evaluation, Journal of Economic Literature 47:1, 1-81

Imbens, Guido and Donald Rubin, 2015, Causal Inference for Statistics, Social, and Biomedical Sciences: An Introduction, Cambridge University Press, New York.

Jang, Yeejin, 2013, Does International Corporate Diversification Improve Access to Capital? Ohio State University Working Paper.

Johnson, Robert C., 2014, Trade in Intermediate Inputs and Business Cycle Comovement, American Economic Journal: Macroeconomics 6(4), 39-83.

Kahle, Kathy and Rene Stulz, 2013, Access to Capital, Investment, and the Financial Crisis, Journal of Financial Economics 110, 280-299.

Kalemli-Özcan, Şebnem, Se-Jik Kim, Hyun Song Shin, Bent E. Sørensen, and Sevcan Yeşiltaş, 2014 "Financial shocks in production chains," working paper.

Kalemli-Özcan, Şebnem, E. Papaioannou, and J. L. Peydró, 2013. Financial regulation, financial globalization, and the synchronization of economic activity. The Journal of Finance, 68(3), pp.1179-1228.

Kashiwagi, Yuzuka, Yasuyuki Todo, and Petr Matous, 2018, International propagation of economic shocks through global supply chains. Vol. 1810. WINPEC working paper, 2018.

Kelly, Bryan, Hanno Lustig, and Stijn Van Nieuwerburgh, 2013, Firm Volatility in Granular Networks, NBER Working Paper No. 19466.

Khwaja, Asim, and Atif Mian, 2008, Tracing the impact of bank liquidity shocks: Evidence from an emerging market, American Economic Review 98, 1413-1442.

Kolay, Madhuparna, Michael Lemmon, and Elizabeth Tashjian. "Spreading the misery? Sources of bankruptcy spillover in the supply chain." Journal of Financial and Quantitative Analysis 51, no. 6 (2016): 1955-1990. 
Kose, M. Ayhan, and Kei-Mu Yi, 2001, International Trade and Business Cycles: Is Vertical Specialization the Missing Link? The American Economic Review 91(2), 371-375.

La Porta, Rafael, Florencio Lopez-de-Silanes, and Andrei Shleifer, 1999, "Corporate ownership around the world." The Journal of Finance 54 (2), 471-517.

Matvos, Gregor, and Amit Seru, 2014. "Resource allocation within firms and financial market dislocation: Evidence from diversified conglomerates." The Review of Financial Studies 27, no. 4 (2014): 1143-1189.

Miller, Ronald E., and Peter D. Blair, 2009. Input-Output Analysis: Foundations and Extensions. Cambridge University Press.

Peek, Joe, and Eric Rosengren, 1997, The international propagation of financial shocks: The case of Japan, American Economic Review 87, 495-505.

Peek, Joe, and Eric Rosengren, 2000, Collateral damage: Effects of the Japanese bank crisis on real activity in the United States, American Economic Review 90, 30-45.

Ramondo, Natalia, Veronica Rappaport, and Kim J. Ruhl, 2016, Intrafirm Trade and Vertical Fragmentation in U.S. Multinational Corporations, Journal of International Economics 98, 51-59.

Santioni, Raffaele, Fabio Schiantarelli, and Philip E. Strahan, 2017. Internal capital markets in times of crisis: The benefit of group affiliation in Italy. No. w23541. National Bureau of Economic Research.

Schnabl, Philipp, 2012, Financial globalization and the propagation of bank liquidity shocks: Evidence from an emerging market, Journal of Finance 67, 897-932.

Wu, Di, 2016, Shock Spillover and Financial Response in Supply Chain Networks: Evidence from Firm-Level Data, Working Paper.

Whited, Toni M., and Guojun Wu, 2006. "Financial constraints risk." The Review of Financial Studies 19, no. 2 (2006): 531-559

Yeaple, Stephen Ross, 2013, The Multinational Firm, Annual Review of Economics 5, 193 217. 


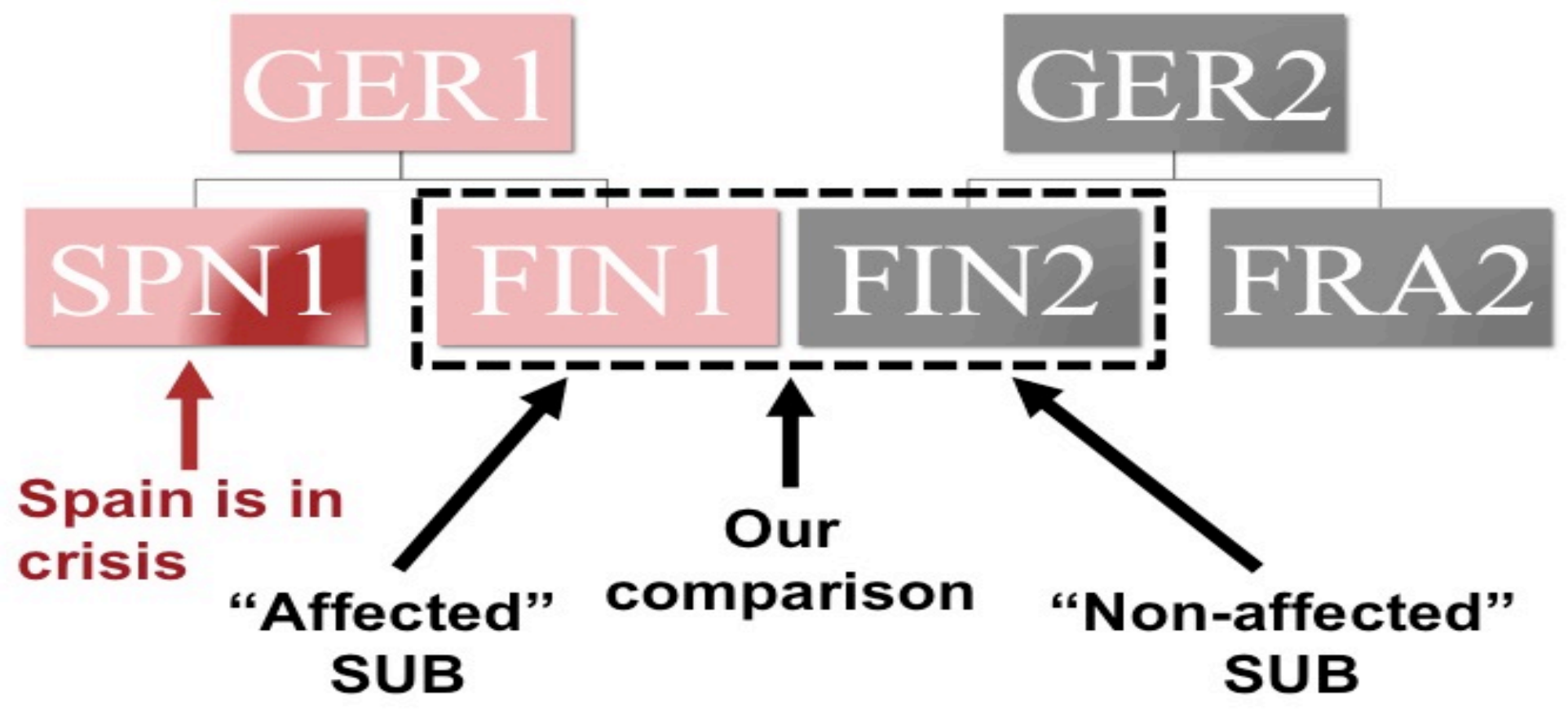

Figure 1. Matched Treated and Control Observations

Treated subsidiaries are matched to control subsidiaries in the same country. Parent MNCs of both treated and control subsidiaries are required to be located in the same country. Not depicted is the requirement for both treated and control subsidiaries to operate in the same industry and the comparison takes place using accounting data from the same year. 

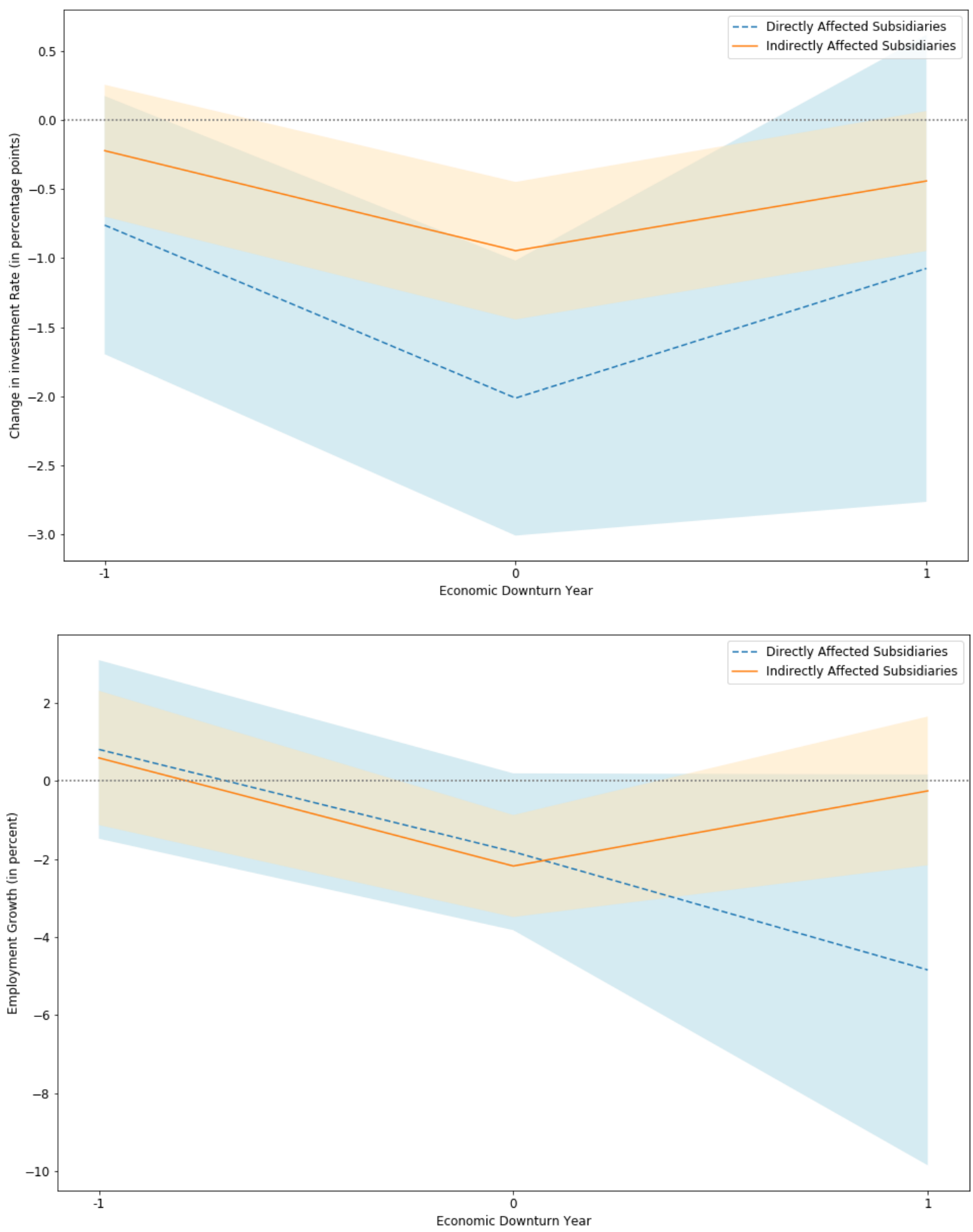

Figure 2. Investment and Employment Growth Around the Downturn Year

This graph presents the difference in the Investment Rate (top panel) and Employment Growth (bottom panel) both in the directly-affected subsidiaries, which are located in countries experiencing economic downturns, and the indirectly affected subsidiaries, which are located in other countries but are owned by the same parents. The differences are with respect to a matched control sample and estimated using a regression analysis described in Section 5. Shaded areas designate the $95 \%$ confidence interval. 
Table 1 - Distribution of Subsidiary and Parent Firms' Countries across Years

We present the countries experiencing economic downturns used as sources of treatment and the distribution of subsidiaries and parent firms across countries and years in the matched sample for our treatment/control sample. A parent is treated if it has a subsidiary in a country experiencing an economic downturn that year with the economic downturn defined as a real GDP growth at least two standard deviations less than the country's long-term average. To construct our control sample, we use Mahalanobis matching with exact matching for subsidiary country, subsidiary 2-digit industry classification, parent country, and year in addition to (nearest neighbor) matching on parent and subsidiary sizes, as measured by the natural logarithm of their total assets. No downturns in 2009 could be used as a source of treatment due to the scarcity of potential control observations that year and the requirement for the parents to be located in a country not experiencing a downturn, an eligibility condition to construct a clean treatment sample. We require our main dependent variable of interest, subsidiary investment, which is defined as the change in fixed assets plus depreciation, normalized by lagged total assets, as well as other main continuous variables of interest (i.e., parent cash flow and lagged subsidiary investment) to be non-missing to be in the final sample. Panel $\mathrm{C}$ counts a parent as many times as it has treated subsidiaries to show the distribution. Panel D provides statistics on investment and employment growth for the subsidiaries in the crisis countries during the crisis year and the year before; these subsidiaries are excluded from the main analysis. Subsidiary Employment Growth is defined as $\ln (\operatorname{employment}(\mathrm{t}) /$ employment(t-1)) of the subsidiary.

Panel A: Economic Downturns Used in the Analysis

\begin{tabular}{ll}
\hline Country Name & Year \\
\hline Estonia & 2008 \\
Greece & $2010,2011,2012$ \\
Ireland & 2008 \\
Iceland & 2010 \\
Italy & 2012 \\
Latvia & 2008,2010 \\
Netherlands & 2012 \\
Portugal & 2012 \\
Slovenia & $2010,2011,2012$ \\
Spain & 2012 \\
\hline
\end{tabular}


Panel B: Treated Subsidiaries: Country-Year Distribution

\begin{tabular}{|c|c|c|c|c|}
\hline Country Name & 2008 & 2010 & 2011 & 2012 \\
\hline Austria & 53 & 18 & 15 & \\
\hline Belgium & 237 & 139 & 139 & 187 \\
\hline Czech Republic & 64 & 51 & 43 & \\
\hline Denmark & 85 & 58 & 55 & 5 \\
\hline Finland & 53 & 28 & 26 & 22 \\
\hline France & 231 & 105 & 109 & 350 \\
\hline Germany & 296 & 171 & 110 & 111 \\
\hline Greece & 35 & & & \\
\hline Hungary & 22 & 10 & 8 & \\
\hline Italy & 359 & 218 & 200 & \\
\hline Japan & & & 3 & \\
\hline Korea & 20 & 20 & 15 & 51 \\
\hline Netherlands & 25 & 13 & 7 & \\
\hline Norway & 88 & 49 & 53 & 32 \\
\hline Poland & 62 & 81 & 63 & 14 \\
\hline Portugal & 42 & 21 & 21 & \\
\hline Romania & & & 9 & \\
\hline Singapore & 9 & & & \\
\hline Slovakia & & 6 & 16 & \\
\hline Slovenia & 4 & & & \\
\hline Spain & 318 & 219 & 211 & \\
\hline Sweden & 100 & 53 & 60 & 20 \\
\hline United Kingdom & 421 & 236 & 203 & 571 \\
\hline Total & 2,524 & 1,496 & 1,366 & 1,363 \\
\hline
\end{tabular}


Panel C: Treated Subsidiaries: Parent Firm Country-Year Distribution

\begin{tabular}{lrrrr}
\hline Country Name & 2008 & 2010 & 2011 & 2012 \\
\hline Australia & & & & 3 \\
Belgium & & & & 6 \\
Canada & & & & 5 \\
Denmark & 23 & 8 & 6 & 22 \\
Finland & 7 & & & \\
France & 291 & 268 & 216 & 73 \\
Germany & 184 & 165 & 165 & 41 \\
Ireland & & & & 13 \\
Japan & 139 & 38 & 21 & 193 \\
Korea, Republic of & 3 & & & \\
Netherlands & 74 & 38 & 38 & \\
Spain & 3 & & & \\
Sweden & 109 & 39 & 20 & 75 \\
Switzerland & 66 & 83 & 81 & \\
United Kingdom & 195 & 121 & 113 & 87 \\
United States of America & 1,430 & 736 & 706 & 845 \\
\hline Total & 2,524 & 1,496 & 1,366 & 1,363 \\
\hline
\end{tabular}

Panel D: Subsidiaries in Economic Downturn Countries During the Downturn Year

\begin{tabular}{lrrrr}
\hline & Mean & Median & Std. Dev & N \\
\hline Subsidiary Investment (t) & 2.778 & 1.144 & 5.088 & 1,596 \\
Subsidiary Investment (t-1) & 3.209 & 1.259 & 5.852 & 1,596 \\
Change in Subsidiary Investment (from (t-1) to (t)) & $-0.430^{* * *}$ & $-0.082^{* * * *}$ & 6.410 & 1,596 \\
& & & & \\
Subsidiary Employment Growth (t) & 0.015 & 0.000 & 20.490 & 1,359 \\
Subsidiary Employment Growth (t-1) & 1.635 & 0.000 & 22.249 & 1,359 \\
Change in Subsidiary Empl. Growth (from (t-1) to (t)) & $-1.620^{* *}$ & $-0.054^{* * *}$ & 28.229 & 1,359 \\
\hline
\end{tabular}


Table 2 - Summary Statistics for the Analysis of Subsidiary Investment

This table presents summary statistics for control variables (Panel A), covariate balance (Panel B), and outcome variables (Panel C). Results are presented for the treatment sample and control sample as well as for the full sample. A parent is treated if it has a subsidiary in a country experiencing an economic downturn that year with the economic downturn defined as a real GDP growth at least two standard deviations less than the country's longterm average. To construct our control sample, we use Mahalanobis matching with exact matching for subsidiary country, subsidiary 2-digit industry classification, parent country, and year in addition to (nearest neighbor) matching on parent and subsidiary sizes. Parents and subsidiaries located in a country experiencing an economic downturn are excluded from both treatment and control groups. Subsidiary (Parent) Size is measured by the natural logarithm of the subsidiary (parent) total book assets in millions of Euros Parent Cash Flow is defined as its Operating profit/loss plus depreciation, over total assets. Subsidiary Investment $(t)$ is defined as the change in fixed assets from $(\mathrm{t}-1)$ to $(\mathrm{t})$ plus depreciation $(\mathrm{t})$ of the subsidiary, normalized by total assets $(\mathrm{t}-1)$ and in percentage points. In Panels $\mathrm{A}$ and $\mathrm{C}$, symbols ${ }^{*},{ }^{* *},{ }^{* *}$ denote significance at the $10 \%, 5 \%$, and $1 \%$ respectively, using mean difference test (adjusting for clustering of observations at the parent company level) for the difference in means and Wilcoxon Ranksum Test for the difference in medians in Treatment vs. Control Samples.

\section{Panel A: Summary Statistics of Control Variables}

\begin{tabular}{|c|c|c|c|c|}
\hline Variables & & $\begin{array}{l}\text { Treatment } \\
\text { Sample }\end{array}$ & Control Sample & All \\
\hline \multirow{3}{*}{ Parent Size (t-1) } & Mean & 9.458 & $8.547 * * *$ & 9.002 \\
\hline & Median & 9.544 & $8.661 * * *$ & 9.170 \\
\hline & Std. Dev. & 1.493 & 1.396 & 1.515 \\
\hline \multirow{3}{*}{ Parent Cash Flow (t-1) } & Mean & 0.139 & 0.127 & 0.133 \\
\hline & Median & 0.134 & $0.118 * * *$ & 0.125 \\
\hline & Std. Dev. & 0.070 & 0.069 & 0.069 \\
\hline \multirow{3}{*}{ Subsidiary Size (t-1) } & Mean & 3.320 & $3.015 * * *$ & 3.168 \\
\hline & Median & 3.122 & $2.852 * * *$ & 2.975 \\
\hline & Std. Dev. & 1.566 & 1.335 & 1.463 \\
\hline \multirow{4}{*}{ Subsidiary Investment (t-1) } & Mean & 3.079 & 3.490 & 3.284 \\
\hline & Median & 1.188 & $1.437 * * *$ & 1.334 \\
\hline & Std. Dev. & 5.776 & 6.030 & 5.908 \\
\hline & $\mathrm{N}$ & 6,749 & 6,749 & 13,498 \\
\hline \multicolumn{5}{|l|}{ Panel B: Covariate Balance } \\
\hline \multirow[t]{2}{*}{ Variables } & \multicolumn{2}{|c|}{ Standardized Difference } & \multicolumn{2}{|c|}{ Variance Ratio } \\
\hline & Raw & Matched & Raw & Matchec \\
\hline Parent Size (t-1) & 1.254 & 0.630 & 0.697 & 1.143 \\
\hline Parent Cash Flow (t-1) & 0.239 & 0.183 & 0.725 & 1.038 \\
\hline Subsidiary Size (t-1) & 0.350 & 0.210 & 1.353 & 1.377 \\
\hline Subsidiary Investment (t-1) & -0.027 & -0.070 & 0.899 & 0.918 \\
\hline
\end{tabular}

Panel C: Summary Statistics of Outcome Variables

\begin{tabular}{lrccc}
\hline Variables & & Treatment Sample & Control Sample & All \\
\hline \multirow{3}{*}{ Subsidiary Investment (t) } & Mean & 2.910 & $3.764^{* *}$ & 3.337 \\
& Median & 1.075 & $1.477^{* * *}$ & 1.273 \\
& Std. Dev. & 5.867 & 6.927 & 6.433 \\
\hline \multirow{2}{*}{ Change in Subsidiary } & Mean & -0.169 & 0.275 & 0.0531 \\
Investment (from (t-1) to (t)) & Median & -0.030 & $0.000^{* *}$ & -0.011 \\
& Std. Dev. & 6.875 & 7.125 & 7.005 \\
\hline & $\mathrm{N}$ & 6,749 & 6,749 & 13,498 \\
\hline
\end{tabular}




\section{Table 3 - International Propagation of Economic Downturns by MNCs - Subsidiary Investment}

Panel A reports average treatment effect on the treated (ATET) for the outcome variable Subsidiary Investment $(t)$, which is the change in fixed assets plus depreciation, normalized by lagged total assets, and in percentage points. In constructing the Propagation Treatment Dummy variable, a parent is treated if it has a subsidiary in a country experiencing an economic downturn that year with the economic downturn defined as a real GDP growth at least two standard deviations less than the country's long-term average. To construct our control sample, we use Mahalanobis matching with exact matching for subsidiary country, subsidiary 2-digit industry classification, parent country, and year in addition to (nearest neighbor) matching on parent and subsidiary sizes. Parents and subsidiaries located in a country experiencing an economic downturn are excluded from both treatment and control groups. Subsidiary (Parent) Size is measured by the natural logarithm of the subsidiary (parent) total book assets. Parent Cash Flow is defined as its Operating profit/loss plus depreciation, over total assets. In Panel A, ATET is bias-adjusted by using subsidiary and parent sizes in Column (1), by also parent cash flow in Columns (2), and additionally by lagged subsidiary investment in Column (3). In Panel B, we report regression estimates with standard errors in parentheses, where we again use the Subsidiary Investment $(t)$ as the dependent variable. We include match-pair fixed effects in all specifications. Standard errors in regressions are corrected for clustering of observations at the parent level. All outcome variables are trimmed at the upper and lower 5\% level. All control variables are winsorized at the upper and lower 1\% level and are included in the tests with one lag. Symbols ${ }^{* * * * * *}$ denote significance at the $10 \%, 5 \%$, and $1 \%$ respectively.

\section{$\underline{\text { Panel A: Propagation Treatment - Matching Estimates }}$}

\begin{tabular}{|c|c|c|c|}
\hline & $\begin{array}{c}(1) \\
\text { Subsidiary Investment }\end{array}$ & $\begin{array}{c}(2) \\
\text { Subsidiary Investment }\end{array}$ & $\begin{array}{c}\text { (3) } \\
\text { Subsidiary Investment }\end{array}$ \\
\hline ATET & $-1.223 * * *$ & $-1.266^{* * *}$ & $-0.898 * * *$ \\
\hline Abadie-Imbens robust std. err. & $(0.198)$ & $(0.198)$ & $(0.195)$ \\
\hline N (Matched Observations) & 13,498 & 13,498 & 13,498 \\
\hline Exact Matches & $\begin{array}{l}\text { Subsidiary Country, } \\
\text { Parent Country, } \\
\text { Subsidiary Industry, } \\
\text { Year } \\
\end{array}$ & $\begin{array}{l}\text { Subsidiary Country, } \\
\text { Parent Country, } \\
\text { Subsidiary Industry, } \\
\text { Year } \\
\end{array}$ & $\begin{array}{l}\text { Subsidiary Country, } \\
\text { Parent Country, } \\
\text { Subsidiary Industry, } \\
\text { Year } \\
\end{array}$ \\
\hline $\begin{array}{l}\text { Nearest Neighborhood Mahalanobis } \\
\text { matching }\end{array}$ & $\begin{array}{l}\text { Subsidiary Size }(\mathrm{t}-1) \\
\text { Parent Size }(\mathrm{t}-1)\end{array}$ & $\begin{array}{l}\text { Subsidiary Size }(\mathrm{t}-1) \\
\text { Parent Size }(\mathrm{t}-1)\end{array}$ & $\begin{array}{c}\text { Subsidiary Size }(\mathrm{t}-1) \\
\text { Parent Size }(\mathrm{t}-1)\end{array}$ \\
\hline Bias-adj variables & $\begin{array}{l}\text { Subsidiary Size }(\mathrm{t}-1) \\
\text { Parent Size }(\mathrm{t}-1)\end{array}$ & $\begin{array}{c}\text { Subsidiary Size (t-1), } \\
\text { Parent Size (t-1), } \\
\text { Parent Cash Flow (t-1) }\end{array}$ & $\begin{array}{c}\text { Subsidiary Size (t-1), } \\
\text { Parent Size (t-1), } \\
\text { Parent Cash Flow (t-1), } \\
\text { Subsidiary Investment }(\mathrm{t}-1)\end{array}$ \\
\hline
\end{tabular}


$\underline{\text { Panel B: Propagation Treatment - Regression Estimates }}$

(1) Subsidiary Investment $-0.854 * * *$ $(0.227)$

Propagation Treatment Dummy

Subsidiary Size (t-1)

Parent Size (t-1)

Parent Cash Flow (t-1)

Subsidiary Investment (t-1)

\section{(2)} Subsidiary Investment $-0.946^{* * *}$

$(0.253)$

0.095

$(0.161)$

0.005

$(0.148)$

$4.607 * *$

(2.064)
(3) Subsidiary Investment

$-0.710 * * *$

$(0.216)$

0.007

$(0.155)$

$-0.049$

$(0.130)$

$3.256^{*}$

(1.826)

$0.348 * * *$

(0.032)

\begin{tabular}{|c|c|c|c|}
\hline Fixed Effects & Match pair & Match pair & Match pair \\
\hline N (Matched Observations) & 13,498 & 13,498 & 13,498 \\
\hline$R^{2}$ & 0.538 & 0.539 & 0.588 \\
\hline N (Firms) & 5,600 & 5,600 & 5,600 \\
\hline N (Clusters/Parents) & 1,145 & 1,145 & 1,145 \\
\hline
\end{tabular}


Table 4 - Summary Statistics for the Analysis of Subsidiary Employment Growth

This table presents summary statistics for control variables (Panel A), covariate balance (Panel B), and outcome variables (Panel C). Results are presented for the treatment sample and control sample as well as for the full sample. A parent is treated if it has a subsidiary in a country experiencing an economic downturn that year with the economic downturn defined as a real GDP growth at least two standard deviations less than the country's longterm average. To construct our control sample, we use Mahalanobis matching with exact matching for subsidiary country, subsidiary 2-digit industry classification, parent country, and year in addition to (nearest neighbor) matching on parent and subsidiary sizes. Parents and subsidiaries located in a country experiencing an economic downturn are excluded from both treatment and control groups. Subsidiary (Parent) Size is measured by the natural logarithm of the subsidiary (parent) total book assets in millions of Euros. Parent Cash Flow is defined as its Operating profit/loss plus depreciation, over total assets. Subsidiary Employment Growth is defined as $\ln ($ employment $(\mathrm{t}) /$ employment $(\mathrm{t}-1))$ of the subsidiary. In Panels A and C, symbols ${ }^{*},{ }^{* *},{ }^{* * *}$ denote significance at the $10 \%, 5 \%$, and $1 \%$ respectively, using mean difference test (adjusting for clustering of observations at the parent company level) for the difference in means and Wilcoxon Ranksum Test for the difference in medians in Treatment vs. Control Samples.

Panel A: Summary Statistics of Control Variables

\begin{tabular}{lrccc}
\hline Variables & & Treatment Sample & Control Sample & All \\
\hline \multirow{2}{*}{ Parent Size (t-1) } & Mean & 9.499 & $8.649 * * *$ & 9.074 \\
& Median & 9.567 & $8.693 * * *$ & 9.200 \\
& Std. Dev. & 1.451 & 1.324 & 1.453 \\
\hline \multirow{2}{*}{ Parent Cash Flow (t-1) } & Mean & 0.140 & 0.128 & 0.134 \\
& Median & 0.134 & $0.119^{* * *}$ & 0.126 \\
& Std. Dev. & 0.070 & 0.068 & 0.069 \\
\hline \multirow{2}{*}{ Subsidiary Size (t-1) } & Mean & 3.336 & $3.117 * *$ & 3.227 \\
& Median & 3.197 & $2.977 * * *$ & 3.064 \\
\multirow{2}{*}{ Subsidiary Employment } & Std. Dev. & 1.473 & 1.273 & 1.381 \\
Growth (t-1) & Mean & 1.574 & 1.764 & 1.669 \\
& Median & 0.000 & 0.000 & 0.000 \\
& Std. Dev. & 22.561 & 19.143 & 20.921 \\
\hline
\end{tabular}

Panel B: Covariate Balance

\begin{tabular}{lcccc}
\hline Variables & \multicolumn{2}{c}{ Standardized Difference } & \multicolumn{2}{c}{ Variance Ratio } \\
\hline & Raw & Matched & Raw & Matched \\
& & & & \\
Parent Size (t-1) & 1.237 & 0.612 & 0.727 & 1.201 \\
Parent Cash Flow (t-1) & 0.240 & 0.170 & 0.745 & 1.082 \\
Subsidiary Size (t-1) & 0.272 & 0.159 & 1.294 & 1.339 \\
Subsidiary Employment & 0.023 & -0.009 & 1.099 & 1.389 \\
Growth (t-1) & & & & \\
\hline
\end{tabular}

Panel C: Summary Statistics of Outcome Variables

\begin{tabular}{lrccc}
\hline \hline Variables & & Treatment Sample & Control Sample & All \\
\hline \multirow{2}{*}{ Subsidiary Employment } & Mean & -0.238 & 1.437 & 0.600 \\
Growth (t) & Median & 0.000 & 0.000 & 0.000 \\
& Std. Dev. & 22.465 & 19.975 & 21.272 \\
\hline Change in Subsidiary & Mean & -1.812 & -0.327 & -1.070 \\
Employment Growth (from & Median & 0.000 & 0.000 & 0.000 \\
(t-1) to (t)) & Std. Dev. & 30.721 & 26.373 & 28.638 \\
\hline & $\mathrm{N}$ & 5,980 & 5,980 & 11,960 \\
\hline
\end{tabular}


Table 5 - International Propagation of Economic Downturns by MNCs - Subsidiary Employment Growth

Panel A reports average treatment effect on the treated (ATET) for the outcome variable Subsidiary Employment Growth ( $t$ ), which is $\ln ($ employment $(\mathrm{t}) /$ employment $(\mathrm{t}-1))$ of the subsidiary. In constructing the Propagation Treatment Dummy variable, a parent is treated if it has a subsidiary in a country experiencing an economic downturn that year with the economic downturn defined as a real GDP growth at least two standard deviations less than the country's long-term average. To construct our control sample, we use Mahalanobis matching with exact matching for subsidiary country, subsidiary 2-digit industry classification, parent country, and year in addition to (nearest neighbor) matching on parent and subsidiary sizes. Parents and subsidiaries located in a country experiencing an economic downturn are excluded from both treatment and control groups. Subsidiary (Parent) Size is measured by the natural logarithm of the subsidiary (parent) total book assets. Parent Cash Flow is defined as its Operating profit/loss plus depreciation, over total assets. In Panel A, ATET is bias-adjusted by using subsidiary and parent sizes in Column (1), by also parent cash flow in Columns (2), and additionally by lagged subsidiary investment in Column (3). In Panel B, we report regression estimates with standard errors in parentheses, where we again use the Subsidiary Employment Growth $(t)$ as the dependent variable. We include match-pair fixed effects in all specifications. Standard errors in regressions are corrected for clustering of observations at the parent level. All outcome variables are trimmed at the upper and lower 5\% level. All control variables are winsorized at the upper and lower 1\% level and are included in the tests with one lag. Symbols ${ }^{* * * * * *}$ denote significance at the $10 \%, 5 \%$, and $1 \%$ respectively.

\section{Panel A: Propagation Treatment - Matching Estimates}

\section{(1)}

Subsidiary Employment Growth
(2)

Subsidiary Employment Growth $-1.522 * *$

(0.653)

11,960

11,960

Subsidiary Country,

Parent Country,

Exact Matches

Subsidiary Industry, Year

\section{Nearest Neighborhood Mahalanobis}

matching

Bias-adj variables

\section{Subsidiary Size (t-1),}

Parent Size (t-1)

Subsidiary Size (t-1),

Parent Size (t-1)
Subsidiary Country,

Parent Country,

Subsidiary Industry, Year

Subsidiary Size (t-1),

Parent Size (t-1)

Subsidiary Size (t-1),

Parent Size (t-1),

Parent Cash Flow (t-1)
(3)

Subsidiary Employment Growth $-1.542 * *$

(0.653)
11,960

Subsidiary Country,

Parent Country,

Subsidiary Industry, Year

Subsidiary Size (t-1),

Parent Size (t-1)

Subsidiary Size (t-1),

Parent Size (t-1),

Parent Cash Flow (t-1), Subsidiary Employment Growth (t-1) 
$\underline{\text { Panel B: Propagation Treatment - Regression Estimates }}$

(1)

Subsidiary Employment Growt

$-1.675^{* * *}$

(0.553)

Subsidiary Size (t-1)

Parent Size (t-1)

Parent Cash Flow (t-1)

Subsidiary Employment Growth (t-1)
Propagation Treatment Dummy

(2)

Subsidiary Employment Growth

$-2.183 * * *$

$(0.665)$

$-0.137$

$(0.559)$

0.522

$(0.415)$

8.079

(6.835)

$0.053^{*}$

$(0.029)$

\begin{tabular}{lccc}
\hline Fixed Effects & Match pair & Match pair & Match pair \\
\hline $\mathrm{N}$ (Matched Observations) & 11,960 & 11,960 & 11,960 \\
$R^{2}$ & 0.510 & 0.510 & 0.511 \\
$\mathrm{~N}$ (Firms) & 4,943 & 4,943 & 4,943 \\
$\mathrm{~N}$ (Clusters/Parents) & 1,038 & 1,038 & 1,038 \\
\hline
\end{tabular}




\section{Table 6 - The Effect of Natural Disasters}

This table provides the results from repeating our main tests presented in Tables 3 and 5 by using natural disasters instead of economic downturns. We report average treatment effect on the treated (ATET) in Columns (1) and (3) and regression estimates in Columns (2) and (4) with robust standard errors in the parentheses. In constructing the Propagation Treatment Dummy variable, a parent is treated if it has a subsidiary in a country experiencing a large natural disaster that year with the large natural disaster defined as a disaster whose damage as a fraction of GDP is in the top decile of all the natural disasters during our sample period. To construct our control sample, we use Mahalanobis matching with exact matching for subsidiary country, subsidiary 2-digit industry classification, parent country, and year in addition to (nearest neighbor) matching on parent and subsidiary sizes. Parents and subsidiaries located in a country experiencing a large natural disaster are excluded from both treatment and control groups. Subsidiary (Parent) Size is measured by the natural logarithm of the subsidiary (parent) total book assets. Parent Cash Flow is defined as its Operating profit/loss plus depreciation, over total assets. ATETs, reported in Columns (1) and (3) are bias adjusted by all the continuous control variables of interest. Regressions, reported in Columns (2) and (4), include match-pair fixed effects in all specifications. Standard errors are corrected for clustering of observations at the parent firm level. Symbols ${ }^{*},{ }^{* * * * *}$ denote significance at the $10 \%, 5 \%$, and $1 \%$ respectively.

(1)

(2)

(3)

(4)

Subsidiary Investment Subsidiary Investment Subsidiary Employment Subsidiary Employment

\begin{tabular}{lcccc} 
& & & Growth & Growth \\
\hline Estimation Method & Matching & Regression & Matching & Regression \\
\hline ATET / Propagation (DISASTER) & $-0.456^{* * *}$ & $-0.493^{* * *}$ & $-2.320^{* * *}$ & $-1.461^{* *}$ \\
$\begin{array}{l}\text { Treatment Dummy } \\
\text { Standard Errors }\end{array}$ & $(0.187)$ & $(0.199)$ & $(0.642)$ & $(0.662)$
\end{tabular}

\begin{tabular}{lccc}
\hline Bias-adj Variables/Controls & \multicolumn{3}{c}{ Subsidiary Size (t-1), Parent Size (t-1), } \\
& And Parent Cash Flow (t-1), Subsidiary Investment/ Employment Growth (t-1) \\
\hline Fixed Effects & Match pair & Match pair \\
\hline N (Matched Observations) & 9,642 & 9,642 & 8,678 \\
$R^{2}$ & 0.575 & 0.521 \\
N (Firms) & 4,630 & 4,143 \\
N (Clusters/Parents) & 1,695 & 1,609 \\
\hline
\end{tabular}


Table 7 - Pre- and Post-Downturn Outcomes

This table provides regression estimates where the dependent variable is as of the year before (t-1)_or the year after $(t+1)$ the treatment event. The first regression in both panels is copied from the main analysis as a 'memo' item. In regression (3), the sample is restricted to the subsidiaries that were eligible to be a control observation in the previous two years before the main treatment event. In constructing the Propagation Treatment Dummy variable, a parent is treated if it has a subsidiary in a country experiencing an economic downturn that year with the economic downturn defined as a real GDP growth at least two standard deviations less than the country's long-term average. Parents and subsidiaries located in a country experiencing an economic downturn are excluded from both treatment and control groups. Results are reported for the Subsidiary Investment, defined as the change in fixed assets plus depreciation, normalized by lagged total assets and in percentage points, in Panel A, and for the Subsidiary Employment Growth, defined as the natural logarithm of the employment over lagged employment of the subsidiary, in Panel B. Subsidiary (Parent) Size is measured by the natural logarithm of the subsidiary (parent) total book assets. Parent Cash Flow is defined as its Operating profit/loss plus depreciation, over total assets. Standard errors are in parentheses and are corrected for clustering of observations at the parent firm level. Symbols ${ }^{*}{ }^{* *},{ }^{* * *}$ denote significance at the $10 \%, 5 \%$, and $1 \%$ respectively.

Panel A. Subsidiary Investment

\begin{tabular}{|c|c|c|c|}
\hline & $\begin{array}{c}(1) \\
\text { Subsidiary } \\
\text { Investment }(\mathrm{t})\end{array}$ & $\begin{array}{c}(2) \\
\text { Subsidiary } \\
\text { Investment }(\mathrm{t}+1)\end{array}$ & $\begin{array}{c}\text { (3) } \\
\text { Subsidiary } \\
\text { Investment (t-1) }\end{array}$ \\
\hline \multirow{2}{*}{$\begin{array}{l}\text { Propagation Treatment } \\
\text { Dummy }\end{array}$} & $-0.946^{* * *}$ & $-0.442 *$ & -0.222 \\
\hline & $(0.253)$ & $(0.258)$ & $(0.243)$ \\
\hline Subsidiary Size (t-1) & $\begin{array}{c}0.095 \\
(0.161)\end{array}$ & $\begin{array}{l}-0.127 \\
(0.194)\end{array}$ & $\begin{array}{c}0.151 \\
(0.198)\end{array}$ \\
\hline Parent Size (t-1) & $\begin{array}{c}0.005 \\
(0.148)\end{array}$ & $\begin{array}{c}0.235 \\
(0.179)\end{array}$ & $\begin{array}{c}0.127 \\
(0.152)\end{array}$ \\
\hline Parent Cash Flow (t-1) & $\begin{array}{l}4.607 * * \\
(2.064)\end{array}$ & $\begin{array}{l}2.883 \\
(2.318)\end{array}$ & $\begin{array}{l}3.498 * \\
(1.863)\end{array}$ \\
\hline Constant & $\begin{array}{l}2.851^{* *} \\
(1.413)\end{array}$ & $\begin{array}{c}0.988 \\
(1.336)\end{array}$ & $\begin{array}{c}1.230 \\
(1.150)\end{array}$ \\
\hline Fixed Effects & Match Pair & Match Pair & Match Pair \\
\hline $\begin{array}{l}\text { Nearest Neighborhood } \\
\text { Mahalanobis matching }\end{array}$ & \multicolumn{3}{|c|}{ Subsidiary Size $(\mathrm{t}-1)$, Parent Size $(\mathrm{t}-1)$} \\
\hline Sample & Full M & Sample & $\begin{array}{l}\text { Matched Sample } \\
\text { with "No Crisis } \\
\text { Last Year" Filter }\end{array}$ \\
\hline N (Matched Observations) & 13,498 & 8,787 & 6,968 \\
\hline$R^{2}$ & 0.539 & 0.592 & 0.527 \\
\hline $\mathrm{N}$ (Firms) & 5,600 & 3,980 & 4,382 \\
\hline $\mathrm{N}$ (Clusters/Parents) & 1,145 & 799 & 1,047 \\
\hline
\end{tabular}


Panel B. Subsidiary Employment Growth

\begin{tabular}{|c|c|c|c|}
\hline & $\begin{array}{c}(1) \\
\text { Subsidiary } \\
\text { Employment } \\
\text { Growth (t) }\end{array}$ & $\begin{array}{c}(2) \\
\text { Subsidiary } \\
\text { Employment } \\
\text { Growth }(\mathrm{t}+1)\end{array}$ & $\begin{array}{c}(3) \\
\text { Subsidiary } \\
\text { Employment } \\
\text { Growth (t-1) }\end{array}$ \\
\hline Propagation Treatment & $-2.183 * * *$ & -0.261 & 0.584 \\
\hline & $(0.665)$ & $(0.969)$ & $(0.876)$ \\
\hline Subsidiary Size (t-1) & $\begin{array}{l}-0.137 \\
(0.559)\end{array}$ & $\begin{array}{c}0.701 \\
(0.871)\end{array}$ & $\begin{array}{l}-0.469 \\
(0.746)\end{array}$ \\
\hline Parent Size (t-1) & $\begin{array}{c}0.522 \\
(0.415)\end{array}$ & $\begin{array}{l}-0.111 \\
(0.675)\end{array}$ & $\begin{array}{l}-0.545 \\
(0.487)\end{array}$ \\
\hline Parent Cash Flow (t-1) & $\begin{array}{c}8.079 \\
(6.835)\end{array}$ & $\begin{array}{c}1.047 \\
(9.737)\end{array}$ & $\begin{array}{c}6.916 \\
(6.918)\end{array}$ \\
\hline Constant & $\begin{array}{l}-3.687 \\
(3.724) \\
\end{array}$ & $\begin{array}{l}-3.079 \\
(6.547) \\
\end{array}$ & $\begin{array}{l}8.314^{*} \\
(4.293) \\
\end{array}$ \\
\hline Fixed Effects & Match Pair & Match Pair & Match Pair \\
\hline $\begin{array}{l}\text { Nearest Neighborhood } \\
\text { Mahalanobis matching }\end{array}$ & \multicolumn{3}{|c|}{ Subsidiary Size (t-1), Parent Size (t-1) } \\
\hline Sample & \multicolumn{2}{|c|}{ Full Matched Sample } & $\begin{array}{l}\text { Matched Sample } \\
\text { with "No Crisis } \\
\text { Last Year" Filter }\end{array}$ \\
\hline $\begin{array}{l}\mathrm{N} \text { (Matched } \\
\text { Observations) }\end{array}$ & 11,960 & 8,198 & 6,292 \\
\hline$R^{2}$ & 0.510 & 0.584 & 0.515 \\
\hline N (Firms) & 4,943 & 3,697 & 3,994 \\
\hline N (Clusters/Parents) & 1,038 & 763 & 966 \\
\hline
\end{tabular}




\section{Table 8 - Alternative Economic Downturn Definitions}

This table provides robustness tests for our main tests presented in Tables 3 and 5 to different economic downturn definitions. We report average treatment effect on the treated (ATET) in Columns (1) and (3) and regression estimates in Columns (2) and (4) with robust standard errors in the parentheses. In constructing the Propagation Treatment Dummy variable, a parent is treated if it has a subsidiary in a country experiencing an economic downturn that year with the economic downturn defined as a real GDP growth less than the country's long-term average at different thresholds. To construct our control sample, we use Mahalanobis matching with exact matching for subsidiary country, subsidiary 2-digit industry classification, parent country, and year in addition to (nearest neighbor) matching on parent and subsidiary sizes. Parents and subsidiaries located in a country experiencing an economic downturn are excluded from both treatment and control groups. Results are reported for the Subsidiary Investment $(t)$, defined as the change in fixed assets plus depreciation, normalized by lagged total assets, and in percentage points, Subsidiary Employment Growth $(t)$, defined as $\ln ($ employment(t) / employment(t-1)) of the subsidiary. Subsidiary (Parent) Size is measured by the natural logarithm of the subsidiary (parent) total book assets. Parent Cash Flow is defined as its Operating profit/loss plus depreciation, over total assets. ATETs, reported in Columns (1) and (3) are bias adjusted by all the continuous control variables of interest. Regressions, reported in Columns (2) and (4), include match-pair fixed effects in all specifications. Standard errors are corrected for clustering of observations at the parent firm level. Symbols ${ }^{*},{ }^{* * * *}$ denote significance at the $10 \%, 5 \%$, and $1 \%$ respectively. 
(1)

(2)

(3)

(4)

Subsidiary Investment Subsidiary Investment Subsidiary Employment Subsidiary Employment

\begin{tabular}{lccc} 
& & Growth & Growth \\
\hline Estimation Method & Matching & Regression & Matching \\
\hline \multicolumn{2}{c}{ Economic downturn cutoffs set to -1.75} & standard deviations below long-term country averages for both Treatment and Control samples & $-2.886^{* * *}$ \\
\hline ATET / Propagation Treatment & $-0.788^{* * *}$ & $-0.598^{* * *}$ & $-2.654 * *$ \\
Dummy & & $(0.175)$ & $(0.633)$
\end{tabular}

Economic downturn cutoffs set to -2.25 standard deviations below long-term country averages for both Treatment and Control samples

\begin{tabular}{lccc}
\hline ATET / Propagation Treatment & $-0.906 * * *$ & $-0.710 * * *$ & $-1.528 * *$ \\
Dummy & & & \\
Standard Errors & $(0.196)$ & $(0.216)$ & $(0.654)$
\end{tabular}

Economic downturn cutoff set to 1 standard deviation below long-term country average for the Control sample (Treatment sample uses the

\begin{tabular}{|c|c|c|c|c|}
\hline $\begin{array}{l}\text { ATET / Propagation Treatment } \\
\text { Dummy } \\
\text { Standard Errors }\end{array}$ & $-0.855 * * *$ & $-0.664 * * *$ & $-1.598 * *$ & $-2.055 * * *$ \\
\hline \multicolumn{5}{|c|}{ No Economic Downturn in the Previous Year (Lagged Propagation Treatment Dummy Equals Zero) } \\
\hline $\begin{array}{l}\text { ATET / Propagation Treatment } \\
\text { Dummy }\end{array}$ & $-0.680 * * *$ & $-0.599 * *$ & $-2.096 * *$ & $-2.978 * * *$ \\
\hline Standard Errors & $(0.266)$ & $(0.292)$ & $(0.924)$ & $(0.851)$ \\
\hline
\end{tabular}


Table 9 - Regression Analysis on the Unbalanced Sample

This table provides regression estimates using the full unbalanced sample for subsidiary investment and subsidiary employment growth. Regressions in Panel A include various interactions of subsidiary country, subsidiary 2-digit industry classification, parent country, and year fixed effects (as specified in the relevant row of the table below). Regressions in Panel B also include parent firm fixed effects. In constructing the Propagation Treatment Dummy variable, a parent is treated if it has a subsidiary in a country experiencing an economic downturn that year with the economic downturn defined as a real GDP growth at least two standard deviations less than the country's long-term average. Parents and subsidiaries located in a country experiencing an economic downturn are excluded from both treatment and control groups. Results are reported for the Subsidiary Investment, defined as the change in fixed assets plus depreciation, normalized by lagged total assets and in percentage points, in Columns (1)-(3) and for the Subsidiary Employment Growth, defined as $\ln ($ employment(t) / employment(t-1)) of the subsidiary Columns (4)-(6). Subsidiary (Parent) Size is measured by the natural logarithm of the subsidiary (parent) total book assets. Parent Cash Flow is defined as its Operating profit/loss plus depreciation, over total assets. Standard errors are in parentheses and are corrected for clustering of observations at the parent firm level. Symbols ${ }^{* * *},{ }^{* * *}$ denote significance at the $10 \%, 5 \%$, and $1 \%$ respectively.

Panel A. Various Fixed Effects

(1) $\quad(2)$

(2)

(3)

(4)

(5)

(6)

Subsidiary Investment $\quad$ Subsidiary Employment Growth

\begin{tabular}{|c|c|c|c|c|c|c|}
\hline \multicolumn{7}{|l|}{ Propagation } \\
\hline Treatment & $-0.382 * * *$ & $-0.390 * * *$ & $-0.355 * * *$ & $-0.710 * *$ & $-0.775 * *$ & $-0.742 * *$ \\
\hline & $(0.099)$ & $(0.099)$ & $(0.098)$ & $(0.343)$ & $(0.352)$ & $(0.353)$ \\
\hline Subsidiary Size & 0.041 & 0.039 & 0.038 & 0.080 & 0.081 & 0.091 \\
\hline & $(0.027)$ & $(0.027)$ & $(0.027)$ & $(0.108)$ & $(0.108)$ & $(0.108)$ \\
\hline Parent Size (t-1) & $\begin{array}{c}0.022 \\
(0.026)\end{array}$ & $\begin{array}{c}0.021 \\
(0.026)\end{array}$ & $\begin{array}{c}0.015 \\
(0.026)\end{array}$ & $\begin{array}{c}-0.315^{* * *} \\
(0.089)\end{array}$ & $\begin{array}{c}-0.314 * * * \\
(0.089)\end{array}$ & $\begin{array}{c}-0.320^{* * *} \\
(0.090)\end{array}$ \\
\hline Parent Cash Flow & $3.406 * * *$ & $3.432 * * *$ & $3.333 * * *$ & $13.508 * * *$ & $13.722 * * *$ & $13.852 * * *$ \\
\hline & $(0.568)$ & $(0.571)$ & $(0.570)$ & $(1.930)$ & $(1.935)$ & $(1.942)$ \\
\hline \multirow{2}{*}{$\begin{array}{l}\text { Subsidiary } \\
\text { Investment } \\
\text { /Employment } \\
\text { Growth (t-1) }\end{array}$} & $0.303 * * *$ & $0.303 * * *$ & $0.303 * * *$ & $0.038 * * *$ & $0.038 * * *$ & $0.037 * * *$ \\
\hline & $(0.008)$ & $(0.008)$ & $(0.008)$ & $(0.012)$ & $(0.012)$ & $(0.012)$ \\
\hline Fixed Effects & $\begin{array}{l}\text { Subsidiary } \\
\text { Country, } \\
\text { Parent } \\
\text { Country, } \\
\text { Subsidiary } \\
\text { Industry, } \\
\text { Year }\end{array}$ & $\begin{array}{c}\text { Parent } \\
\text { Country } \times \\
\text { Year, } \\
\text { Subsidiary } \\
\text { Country, } \\
\text { Subsidiary } \\
\text { Industry }\end{array}$ & $\begin{array}{c}\text { Parent } \\
\text { Country } \times \\
\text { Year, } \\
\text { Subsidiary } \\
\text { Country } \times \\
\text { Year, } \\
\text { Subsidiary } \\
\text { Industry } \\
\end{array}$ & $\begin{array}{c}\text { Subsidiary } \\
\text { Country, } \\
\text { Parent } \\
\text { Country, } \\
\text { Subsidiary } \\
\text { Industry, } \\
\text { Year }\end{array}$ & $\begin{array}{c}\text { Parent } \\
\text { Country } \times \\
\text { Year, } \\
\text { Subsidiary } \\
\text { Country, } \\
\text { Subsidiary } \\
\text { Industry }\end{array}$ & $\begin{array}{c}\text { Parent } \\
\text { Country } \times \\
\text { Year, } \\
\text { Subsidiary } \\
\text { Country } \times \\
\text { Year, } \\
\text { Subsidiary } \\
\text { Industry }\end{array}$ \\
\hline $\mathrm{N}$ & 40,847 & 40,814 & 40,796 & 38,149 & 38,126 & 38,112 \\
\hline$R^{2}$ & 0.144 & 0.149 & 0.178 & 0.020 & 0.024 & 0.030 \\
\hline $\mathrm{N}$ (parents) & 3,221 & 3,215 & 3,215 & 3,093 & 3,088 & 3,087 \\
\hline
\end{tabular}


Panel B. Parent Firm Fixed Effects Together with Various Fixed Effects

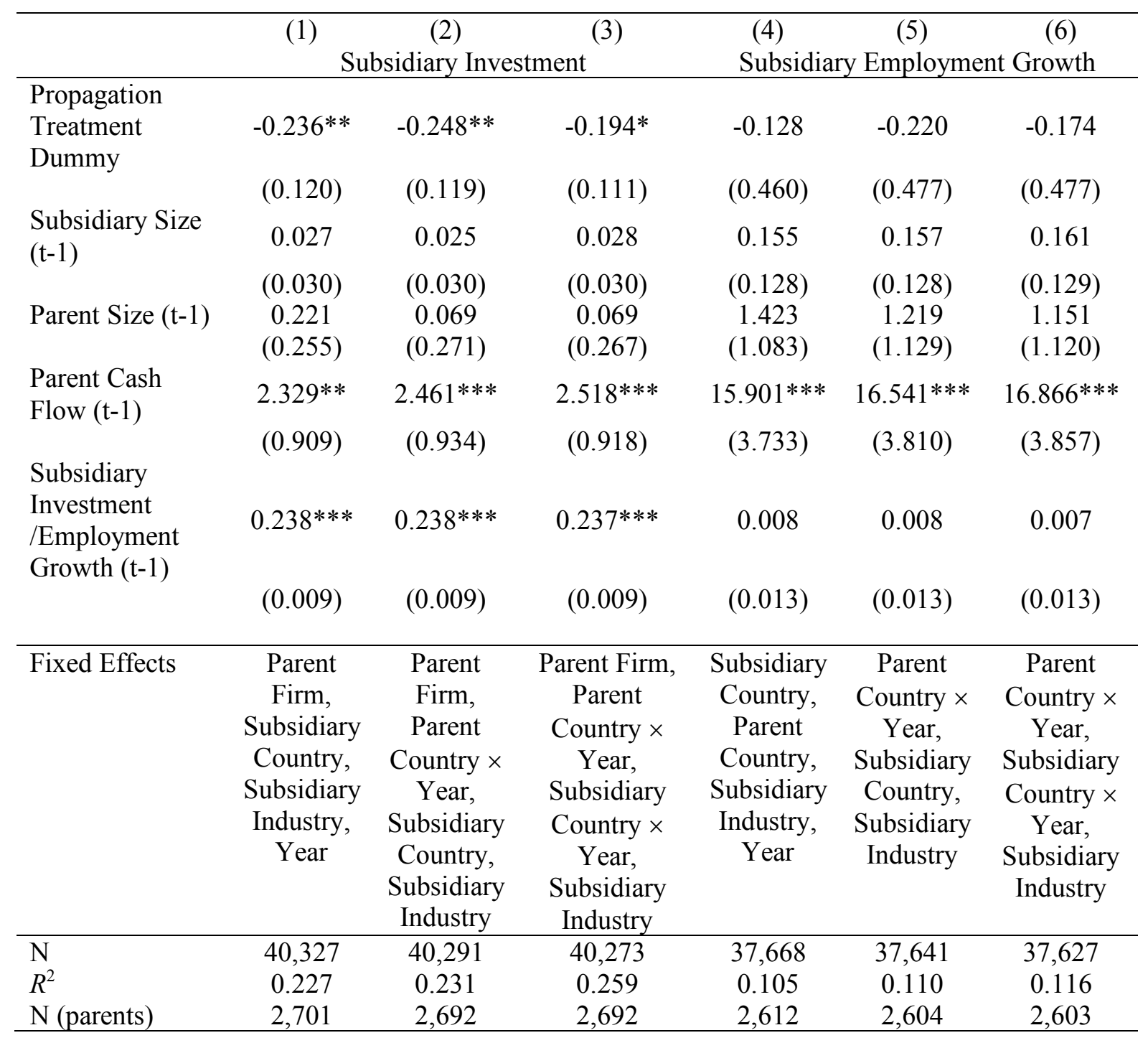


Table 10 - Impact of the International Propagation on Destination Economies

Table reports regression estimates of industry total sales and employment on propagation share using country-industry panel for the 2008-2012 period. In Panel B, the dependent variable is the natural logarithm of total country-industry sales in regressions (1)-(4) and the natural logarithm of total country-industry employment in regressions (5)-(8). In Panel C, the dependent variable is the natural logarithm of total country-industry sales in regressions (1)-(2) and the natural logarithm of total country-industry employment in regressions (3)-(4). Propagation Share is measured by the sum of lagged sales or employment of foreign subsidiaries by treated parent firms in each country not experiencing an economic downturn, industry, and year scaled by the lagged total countryindustry-year sales or employment, depending on the dependent variable. A parent firm is treated in a given year if it is headquartered in a country not experiencing an economic downturn but has a subsidiary in a country that is experiencing one that year. The economic downturn is defined as a real GDP growth at least two standard deviations less than the country's long-term average. Size of Foreign Subsidiaries is the sum of lagged sales or employment of all foreign subsidiaries in each country-industry-year. Share of Subsidiaries from Parent Countries That Have an economic downturn is the lagged sales or employment share of foreign subsidiaries whose parents are headquartered in a country that have an economic downturn in a given year. In Panel C, leads and lags of Propagation Share are obtained by normalizing leads and lags of the numerator with the denominator always measured as of $t-1$ to avoid simultaneity. Panel A shows descriptive statistics of the main variables corresponding to the samples used in Panel B regressions (2) and (6). Industries are defined at the NACE 3-digit level. Standard errors robust to clustering at the countryindustry level are reported in parentheses. Symbols ${ }^{* * *},{ }^{* * *}$ denote significance at the $10 \%, 5 \%$, and $1 \%$ level respectively.

$\underline{\text { Panel A: Descriptive Statistics }}$

\begin{tabular}{lccccc}
\hline & & Std. & & & \\
& Mean & Dev. & Pctile 10 & Median & Pctile 90 \\
\hline Propagation Share_Sales & 0.046 & 0.129 & 0.000 & 0.000 & 0.126 \\
Ln(Sales) & 7.236 & 1.681 & 5.064 & 7.162 & 9.421 \\
Propagation Share_Empl. & 0.030 & 0.092 & 0.000 & 0.000 & 0.081 \\
Ln(Empl.) & 8.999 & 1.465 & 7.185 & 9.006 & 10.863 \\
\hline & & & & & \\
\hline & Country & Industry & Year & Country & Country \\
& & & & × Industry & $\times$ Year \\
& & & & & \\
\hline $\mathrm{N}$ & 25 & 99 & 4 & & \\
\hline
\end{tabular}


Panel B: Regression Analysis
(1)
(2)
(3)
(4)
(5)
(6)
(7)
(8)

Ln(Sales) Ln(Sales) Ln(Sales) Ln(Sales) Ln(Empl.) Ln(Empl.) Ln(Empl.) Ln(Empl.)

Propagation Share

$-0.303 * *-0.368 * *-1.301 * * *-1.322 * * *-0.367 * * *-0.460 * * *-1.610 * * *-1.711 * * *$

$\begin{array}{llllllll}(0.121) & (0.150) & (0.167) & (0.167) & (0.136) & (0.171) & (0.191) & (0.190)\end{array}$

$\operatorname{Ln}($ Size of Foreign Subsidiaries)

$\begin{array}{cccc}0.162 * * * & 0.166^{* * *} & 0.170^{* * *} & 0.184 * * * \\ (0.013) & (0.013) & (0.013) & (0.014)\end{array}$

Share of Subsidiaries whose Parent Firms

$-0.454 * * *$

$-3.798 * * *$

Reside in Countries with an economic downturn

$(0.172)$

(0.396)

\begin{tabular}{lcccccccc}
\hline Country, Industry, and Year FEs & Yes & No & No & No & Yes & \multicolumn{2}{c}{$\begin{array}{c}\text { No } \\
\text { No }\end{array}$} \\
Country $\times$ year and Industry $\times$ year FEs & No & Yes & Yes & Yes & No & Yes & Yes \\
\hline N (Observations) & 4,477 & 4,466 & 3,091 & 3,091 & 4,541 & 4,528 & 3,012 & 3,012 \\
$R^{2}$ & 0.802 & 0.790 & 0.839 & 0.841 & 0.795 & 0.783 & 0.834 & 0.839 \\
\hline
\end{tabular}


Panel C: Placebo Test

\begin{tabular}{|c|c|c|c|c|}
\hline & $\begin{array}{c}(1) \\
\operatorname{Ln}(\text { Sales })\end{array}$ & $\begin{array}{c}(2) \\
\operatorname{Ln}(\text { Sales })\end{array}$ & $\begin{array}{c}(3) \\
\operatorname{Ln}(\text { Empl. })\end{array}$ & $\begin{array}{c}(4) \\
\operatorname{Ln}(\text { Empl. })\end{array}$ \\
\hline Propagation Share $(\mathrm{t}+2)$ & $\begin{array}{l}-0.024 \\
(0.230)\end{array}$ & $\begin{array}{c}-0.057 \\
(0.233)\end{array}$ & $\begin{array}{l}-0.185 \\
(0.259)\end{array}$ & $\begin{array}{c}-0.101 \\
(0.295)\end{array}$ \\
\hline Propagation Share $(\mathrm{t}+1)$ & $\begin{array}{l}-0.010 \\
(0.329)\end{array}$ & $\begin{array}{c}0.099 \\
(0.350)\end{array}$ & $\begin{array}{c}0.111 \\
(0.337)\end{array}$ & $\begin{array}{c}0.166 \\
(0.403)\end{array}$ \\
\hline Propagation Share & $\begin{array}{c}-0.805^{* *} \\
(0.374)\end{array}$ & $\begin{array}{c}-1.037 * * \\
(0.433)\end{array}$ & $\begin{array}{c}-1.893 * * * \\
(0.353)\end{array}$ & $\begin{array}{l}-2.235 * * * \\
(0.412)\end{array}$ \\
\hline Propagation Share (t-1) & $\begin{array}{l}-0.108 \\
(0.337)\end{array}$ & $\begin{array}{l}-0.096 \\
(0.380)\end{array}$ & $\begin{array}{l}-0.534^{*} \\
(0.319)\end{array}$ & $\begin{array}{l}-0.456 \\
(0.343)\end{array}$ \\
\hline Propagation Share (t-2) & $\begin{array}{l}-0.247 \\
(0.246)\end{array}$ & $\begin{array}{l}-0.270 \\
(0.288)\end{array}$ & $\begin{array}{c}1.137 * * * \\
(0.339)\end{array}$ & $\begin{array}{c}1.117 * * * \\
(0.324)\end{array}$ \\
\hline Ln(Size of Foreign Subsidiaries) & $\begin{array}{c}0.135 * * * \\
(0.011)\end{array}$ & $\begin{array}{c}0.162 * * * \\
(0.013)\end{array}$ & $\begin{array}{c}0.144 * * * \\
(0.012)\end{array}$ & $\begin{array}{c}0.169 * * * \\
(0.013)\end{array}$ \\
\hline $\begin{array}{l}\text { Country, Industry, and Year FEs } \\
\text { Country } \times \text { year and Industry } \times \text { year FEs }\end{array}$ & $\begin{array}{l}\text { Yes } \\
\text { No }\end{array}$ & $\begin{array}{l}\text { No } \\
\text { Yes }\end{array}$ & $\begin{array}{l}\text { Yes } \\
\text { No }\end{array}$ & $\begin{array}{l}\text { No } \\
\text { Yes }\end{array}$ \\
\hline $\begin{array}{l}\mathrm{N} \text { (Observations) } \\
R^{2}\end{array}$ & $\begin{array}{l}3,118 \\
0.841\end{array}$ & $\begin{array}{l}3,091 \\
0.839\end{array}$ & $\begin{array}{l}3,046 \\
0.838\end{array}$ & $\begin{array}{l}3,012 \\
0.835\end{array}$ \\
\hline
\end{tabular}




\section{Table 11 - Supply Chain Links among the Subsidiaries and the Propagation of Economic Downturns}

This table provides regression results about the role of supply chain relationships in the propagation of economic downturns based on the location and industry of the subsidiary that lead the parent firm to be treated. The dependent variable is Subsidiary Investment ( $t$ ), which is the change in fixed assets plus depreciation, normalized by lagged total assets, and in percentage points. In constructing the Propagation Treatment Dummy variable, a parent is treated if it has a subsidiary in a country that experiences an economic downturn that year (henceforth referred as 'affected subsidiary'). The economic downturn defined as a real GDP growth at least two standard deviations less than the country's long-term average. To construct our sample, we use Mahalanobis matching with exact matching for subsidiary country, subsidiary 2-digit industry classification, parent country, and year in addition to (nearest neighbor) matching on parent and subsidiary sizes. Affected Sub in Up Stream is a binary indicator that is equal to one if the input requirement from the country-industry of the affected subsidiary to the subsidiary's country-industry (and vice versa for Affected Sub in Down Stream) is in the top decile in our sample; both measures are defined only for the treated subsidiaries (see text for details). Total input requirement coefficients computed using the country-industry level Input-Output Tables are used to measure the importance of these relationships. Controls include Subsidiary and Parent Size, measured by the natural logarithm of the subsidiary and parent total book assets, respectively, Parent Cash Flow, defined as its Operating profit/loss plus depreciation, over total assets, and Subsidiary Investment (t-1). Regressions include match-pair fixed effects in all specifications. Standard errors are corrected for clustering of observations at the parent firm level. Symbols *, ${ }^{* *},{ }^{* * *}$ denote significance at the $10 \%, 5 \%$, and $1 \%$ respectively. 


\begin{tabular}{|c|c|c|c|c|c|c|c|}
\hline & & (1) & (2) & (3) & $(4)$ & $(5)$ & (6) \\
\hline & & \multicolumn{6}{|c|}{ Subsidiary Investment } \\
\hline Propagation Dummy & (a) & $\begin{array}{c}-0.922 * * * \\
(0.240)\end{array}$ & $\begin{array}{c}-0.7467 * * * \\
(0.225)\end{array}$ & $\begin{array}{c}-0.761 * * * \\
(0.227)\end{array}$ & $\begin{array}{c}-0.609 * * * \\
(0.209)\end{array}$ & $\begin{array}{c}-0.834 * * * \\
(0.240)\end{array}$ & $\begin{array}{c}-0.651 * * * \\
(0.217)\end{array}$ \\
\hline Affected Sub in Up Stream & (b) & $\begin{array}{l}0.754 * \\
(0.455)\end{array}$ & $\begin{array}{l}0.4401 \\
(0.396)\end{array}$ & & & $\begin{array}{l}0.863 * \\
(0.455)\end{array}$ & $\begin{array}{c}0.544 \\
(0.402)\end{array}$ \\
\hline Affected Sub in Down Stream & (b) & & & $\begin{array}{l}-0.892 \\
(0.568)\end{array}$ & $\begin{array}{l}-0.897 * \\
(0.481)\end{array}$ & $\begin{array}{l}-0.983 * \\
(0.565)\end{array}$ & $\begin{array}{c}-0.954 * * \\
(0.481)\end{array}$ \\
\hline Controls & & No & Yes & No & Yes & No & Yes \\
\hline Fixed Effects & & \multicolumn{6}{|c|}{ Match Pair } \\
\hline (a) $+(b)$ & & $\begin{array}{l}-0.002 \\
(0.004) \\
\end{array}$ & $\begin{array}{c}-0.003 \\
(0.004)\end{array}$ & $\begin{array}{c}-0.017 * * * \\
(0.006)\end{array}$ & $\begin{array}{c}-0.0150 * * * \\
(0.005)\end{array}$ & $\begin{array}{l}-0.0095 \\
(0.0068) \\
\end{array}$ & $\begin{array}{c}-0.0106^{*} \\
0.0059 \\
\end{array}$ \\
\hline N (Matched Observations) & & 13,490 & 13,490 & 13,490 & 13,490 & 13,490 & 13,490 \\
\hline$R^{2}$ & & 0.538 & 0.588 & 0.539 & 0.588 & 0.539 & 0.588 \\
\hline N (Firms) & & 5,594 & 5,594 & 5,594 & 5,594 & 5,594 & 5,594 \\
\hline $\mathrm{N}$ (Clusters/Parents) & & 1,142 & 1,142 & 1,142 & 1,142 & 1,142 & 1,142 \\
\hline
\end{tabular}


Table 12 - International Propagation of Economic Downturns by MNCs - The Role of Financial Constraints

This table repeats our main regression analysis in Tables 3 and 5 by interacting the treatment indicator with an indicator for financially constrained firms. WW50 is an indicator that takes the value of one for the parents whose Whited-Wu index is lower than the median index for U.S. Compustat firms. No-Rating is an indicator that takes the value of one for parent firms that do not have a credit rating. The sample in both panels is restricted to U.S. parent firms and is based on matching as in Tables 3 and 5. In constructing the Propagation Treatment Dummy variable, a parent is treated if it has a subsidiary in a country experiencing an economic downturn that year with the economic downturn defined as a real GDP growth at least two standard deviations less than the country's long-term average. To construct our control sample, we use Mahalanobis matching with exact matching for subsidiary country, subsidiary 2-digit industry classification, parent country, and year in addition to (nearest neighbor) matching on parent and subsidiary sizes. Parents and subsidiaries located in a country experiencing an economic downturn are excluded from both treatment and control groups. Subsidiary (Parent) Size is measured by the natural logarithm of the subsidiary (parent) total book assets. Parent Cash Flow is defined as its Operating profit/loss plus depreciation, over total assets. All regressions include match-pair fixed effects. Standard errors are corrected for clustering of observations at the parent firm level. Symbols ${ }^{*},{ }^{* *},{ }^{* * *}$ denote significance at the $10 \%, 5 \%$, and $1 \%$ respectively. 
Panel A: Whited-Wu Index

\begin{tabular}{|c|c|c|c|c|}
\hline & (1) & $\begin{array}{c}\text { (2) } \\
\text { Subsidiary Investment }\end{array}$ & $\begin{array}{l}(3) \\
\text { Subsidiary Employment } \\
\text { Growth }\end{array}$ & $\begin{array}{l}\text { (4) } \\
\text { Subsidiary Employment } \\
\text { Growth }\end{array}$ \\
\hline $\begin{array}{l}\text { Transmission Treatment } \\
\text { Dummy (a) }\end{array}$ & $\begin{array}{c}-0.652 * * \\
(0.275)\end{array}$ & $\begin{array}{c}-0.582 * * \\
(0.280)\end{array}$ & $\begin{array}{c}-2.147 * * \\
(0.895)\end{array}$ & $\begin{array}{c}-1.806^{* *} \\
(0.908)\end{array}$ \\
\hline $\begin{array}{l}\text { Transmission Treatment } \\
\text { Dummy } \times \text { WW50 (b) }\end{array}$ & $\begin{array}{l}-14.183 * * * \\
(4.773)\end{array}$ & $\begin{array}{l}-3.294 * \\
(1.908)\end{array}$ & $\begin{array}{c}-10.362 * * \\
(4.529)\end{array}$ & $\begin{array}{l}-5.565 \\
(4.118)\end{array}$ \\
\hline WW50 & & $\begin{array}{l}19.062 * \\
(11.044)\end{array}$ & & $\begin{array}{c}37.617 \\
(30.228)\end{array}$ \\
\hline$(a)+(b)$ & $\begin{array}{l}-14.835 * * * \\
(4.768)\end{array}$ & $\begin{array}{c}-3.876 * * \\
(1.871) \\
\end{array}$ & $\begin{array}{c}-12.509 * * * \\
(4.426) \\
\end{array}$ & $\begin{array}{l}-7.371 * \\
(3.956) \\
\end{array}$ \\
\hline Fixed Effects & Match pair & Match pair & Match pair & Match pair \\
\hline Controls & $\begin{array}{c}\text { Subsidiary Size (t-1), } \\
\text { Parent Size (t-1), } \\
\text { Parent Cash Flow (t-1), } \\
\text { and Subsidiary } \\
\text { Investment (t-1) }\end{array}$ & $\begin{array}{c}\text { Same as regression (1) } \\
\text { and their interactions with } \\
\text { WW50 }\end{array}$ & $\begin{array}{c}\text { Subsidiary Size (t-1), } \\
\text { Parent Size (t-1), } \\
\text { Parent Cash Flow (t-1), } \\
\text { and Subsidiary } \\
\text { Employment Growth }(\mathrm{t}-1)\end{array}$ & $\begin{array}{c}\text { Same as regression (3) and } \\
\text { their interactions with } \\
\text { WW50 }\end{array}$ \\
\hline Exact Matching Variables & $\begin{array}{c}\text { WW50, Year, } \\
\text { Subsidiary Country, } \\
\text { Parent Country, } \\
\text { Subsidiary Industry } \\
\end{array}$ & $\begin{array}{c}\text { Year, } \\
\text { Subsidiary Country, } \\
\text { Parent Country, } \\
\text { Subsidiary Industry } \\
\end{array}$ & $\begin{array}{c}\text { WW50, Year, } \\
\text { Subsidiary Country, } \\
\text { Parent Country, } \\
\text { Subsidiary Industry } \\
\end{array}$ & $\begin{array}{c}\text { Year, } \\
\text { Subsidiary Country, } \\
\text { Parent Country, } \\
\text { Subsidiary Industry } \\
\end{array}$ \\
\hline N (Matched Observations) & 6,882 & 7,129 & 6,324 & 6,555 \\
\hline$R^{2}$ & 0.585 & 0.599 & 0.512 & 0.524 \\
\hline N (Firms) & 2,750 & 2,869 & 2,521 & 2,628 \\
\hline N (Clusters/Parents) & 476 & 509 & 461 & 489 \\
\hline N (Parents with WW50 = 1) & 12 & 30 & 13 & 29 \\
\hline $\begin{array}{l}\text { N (Treated Parents with } \\
\text { WW50=1) }\end{array}$ & 7 & 16 & 8 & 17 \\
\hline
\end{tabular}


Panel B: Credit Rating

\begin{tabular}{|c|c|c|c|c|}
\hline & $\begin{array}{c}(1) \\
\text { Subsidiary Investment }\end{array}$ & $\begin{array}{c}\text { (2) } \\
\text { Subsidiary Investment }\end{array}$ & $\begin{array}{l}\text { (3) } \\
\text { Subsidiary Employment } \\
\text { Growth }\end{array}$ & $\begin{array}{l}\text { (4) } \\
\text { Subsidiary Employment } \\
\text { Growth }\end{array}$ \\
\hline $\begin{array}{l}\text { Transmission Treatment } \\
\text { Dummy (a) }\end{array}$ & $\begin{array}{l}-0.297 \\
(0.303)\end{array}$ & $\begin{array}{l}-0.543^{*} \\
(0.292)\end{array}$ & $\begin{array}{l}-0.809 \\
(0.883)\end{array}$ & $\begin{array}{l}-0.685 \\
(0.900)\end{array}$ \\
\hline $\begin{array}{l}\text { Transmission Treatment Dummy } \\
\times \text { No-Rating (b) }\end{array}$ & $\begin{array}{l}-0.194 \\
(0.639)\end{array}$ & $\begin{array}{l}-0.486 \\
(0.652)\end{array}$ & $\begin{array}{c}-4.323 * * \\
(2.075)\end{array}$ & $\begin{array}{l}-4.230^{* *} \\
(2.129)\end{array}$ \\
\hline No-Rating & & $\begin{array}{l}-4.328^{*} \\
(2.553)\end{array}$ & & $\begin{array}{l}-7.799 \\
(7.774)\end{array}$ \\
\hline (a) $+(b)$ & $\begin{array}{l}-0.943^{*} \\
(0.573) \\
\end{array}$ & $\begin{array}{c}-1.028^{*} \\
(0.565) \\
\end{array}$ & $\begin{array}{c}-5.132 * * * \\
(1.949) \\
\end{array}$ & $\begin{array}{c}-4.915^{* *} \\
(1.887) \\
\end{array}$ \\
\hline Fixed Effects & Match pair & Match pair & Match pair & Match pair \\
\hline Controls & $\begin{array}{l}\text { Subsidiary Size }(\mathrm{t}-1), \\
\text { Parent Size }(\mathrm{t}-1), \\
\text { Parent Cash Flow }(\mathrm{t}-1), \\
\text { and Subsidiary } \\
\text { Investment }(\mathrm{t}-1)\end{array}$ & $\begin{array}{c}\text { Same as regression (1) and } \\
\text { their interactions with } \\
\text { No-Rating }\end{array}$ & $\begin{array}{c}\text { Subsidiary Size (t-1), } \\
\text { Parent Size (t-1), } \\
\text { Parent Cash Flow (t-1), } \\
\text { and Subsidiary } \\
\text { Employment Growth (t-1) }\end{array}$ & $\begin{array}{c}\text { Same as regression (3) } \\
\text { and their interactions with } \\
\text { No-Rating }\end{array}$ \\
\hline Exact Matching Variables & $\begin{array}{c}\text { No-Rating, Year, } \\
\text { Subsidiary Country, } \\
\text { Parent Country, } \\
\text { Subsidiary Industry } \\
\end{array}$ & $\begin{array}{c}\text { Year, } \\
\text { Subsidiary Country, } \\
\text { Parent Country, } \\
\text { Subsidiary Industry } \\
\end{array}$ & $\begin{array}{l}\text { No-Rating, Year, } \\
\text { Subsidiary Country, } \\
\text { Parent Country, } \\
\text { Subsidiary Industry } \\
\end{array}$ & $\begin{array}{c}\text { Year, } \\
\text { Subsidiary Country, } \\
\text { Parent Country, } \\
\text { Subsidiary Industry } \\
\end{array}$ \\
\hline $\mathrm{N}$ (Matched Observations) & 6,140 & 7,434 & 5,716 & 6,878 \\
\hline$R^{2}$ & 0.567 & 0.586 & 0.506 & 0.509 \\
\hline$N($ Firms) & 2,521 & 2,967 & 2,300 & 2,728 \\
\hline $\mathrm{N}$ (Clusters/Parents) & 471 & 530 & 452 & 510 \\
\hline $\mathrm{N}$ (Parents with No-Rating = 1) & 204 & 245 & 193 & 234 \\
\hline $\begin{array}{l}\text { N (Treated Parents with } \\
\text { No-Rating = 1) }\end{array}$ & 113 & 126 & 108 & 125 \\
\hline
\end{tabular}




\section{Table 13 - International Propagation of Economic Downturns by MNCs - Non-Tradable Industries}

This table repeats our main tests presented in Tables 3 and 5 in a sample restricted to subsidiaries in non-tradable industries. Broad definition of nontradable industries includes all the non-manufacturing industries. Narrow definition includes construction (nace $=45)$, retail trade $(52)$, hotels and restaurants (55), and real estate (70). We report average treatment effect on the treated (ATET) in Columns (1) and (3) and regression estimates in Columns (2) and (4) with robust standard errors in the parentheses. In constructing the Propagation Treatment Dummy variable, a parent is treated if it has a subsidiary in a country experiencing an economic downturn that year with the economic downturn defined as a real GDP growth at least two standard deviations less than the country's long-term average. To construct our control sample, we use Mahalanobis matching with exact matching for subsidiary country, subsidiary 2-digit industry classification, parent country, and year in addition to (nearest neighbor) matching on parent and subsidiary sizes. Parents and subsidiaries located in a country experiencing an economic downturn are excluded from both treatment and control groups. Results are reported for the Subsidiary Investment (t-1), defined as the change in fixed assets plus depreciation, normalized by lagged total assets, and in percentage points, Subsidiary Employment Growth $(t-1)$, defined as $\ln ($ employment $(\mathrm{t}-1)$ / employment(t-2)) of the subsidiary. Subsidiary (Parent) Size is measured by the natural logarithm of the subsidiary (parent) total book assets. Parent Cash Flow is defined as its Operating profit/loss plus depreciation, over total assets. ATETs, reported in Columns (1) and (3) are bias adjusted by all the continuous control variables of interest. Regressions, reported in Columns (2) and (4), include match-pair fixed effects in all specifications. Errors are corrected for clustering of observations at the parent firm level. Symbols ${ }^{*},{ }^{* *},{ }^{* * *}$ denote significance at the $10 \%, 5 \%$, and $1 \%$ respectively.

\section{Panel A: Non-Tradable Industries - Broad Definition}

\begin{tabular}{|c|c|c|c|c|}
\hline & $\begin{array}{c}\text { (1) } \\
\text { Subsidiary } \\
\text { Investment }\end{array}$ & $\begin{array}{c}(2) \\
\text { Subsidiary } \\
\text { Investment }\end{array}$ & $\begin{array}{l}\text { (3) } \\
\text { Subsidiary Employment } \\
\text { Growth }\end{array}$ & $\begin{array}{l}\text { (4) } \\
\text { Subsidiary Employment } \\
\text { Growth }\end{array}$ \\
\hline Estimation Method & Matching & Regression & Matching & Regression \\
\hline $\begin{array}{l}\text { ATET / Propagation Treatment Dummy } \\
\text { Standard Errors }\end{array}$ & $\begin{array}{l}-0.859 * * * \\
(0.228)\end{array}$ & $\begin{array}{c}-0.665 * * * \\
(0.242)\end{array}$ & $\begin{array}{l}-1.116 \\
(0.776)\end{array}$ & $\begin{array}{c}-1.803 * * \\
(0.763)\end{array}$ \\
\hline Bias-adj Variables/Controls & \multicolumn{4}{|c|}{$\begin{array}{l}\text { Subsidiary Size (t-1), Parent Size (t-1), } \\
\text { Flow (t-1), Subsidiary Investment/ Employment Growth (t-1) }\end{array}$} \\
\hline Fixed Effects & & Match pair & & Match pair \\
\hline $\begin{array}{l}\mathrm{N} \text { (Matched Observations) } \\
R^{2} \\
\mathrm{~N} \text { (Firms) } \\
\mathrm{N} \text { (Clusters/Parents) }\end{array}$ & 10,818 & $\begin{array}{c}10,818 \\
0.58 \\
4,401 \\
1,045\end{array}$ & 9,372 & $\begin{array}{c}9,372 \\
0.511 \\
3,750 \\
931\end{array}$ \\
\hline
\end{tabular}


Panel B: Non-Tradable Industries - Narrow Definition

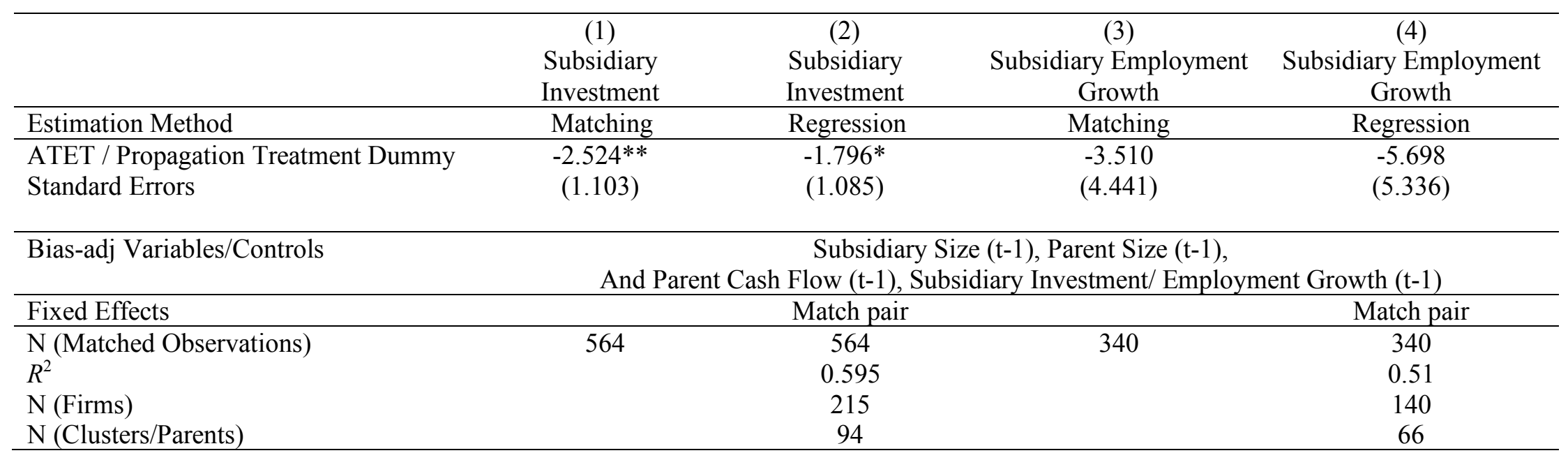


Online Appendix to

"The International Propagation of Economic Downturns Through

Multinational Companies: The Real Economy Channel"

\author{
Jan Bena \\ University of British Columbia \\ Serdar Dinc \\ Rutgers University \\ Isil Erel \\ Ohio State University
}




\section{Table OA-1 - Robustness - Geographic Subsamples}

This table provides robustness tests for our main tests presented in Tables 3 and 5 in different geographic subsamples. We report average treatment effect on the treated (ATET) in Columns (1) and (3) and regression estimates in Columns (2) and (4) with robust standard errors in the parentheses. In constructing the Propagation Treatment Dummy variable, a parent is treated if it has a subsidiary in a country experiencing an economic downturn that year with the economic downturn defined as a real GDP growth at least two standard deviations less than the country's long-term average. To construct our control sample, we use Mahalanobis matching with exact matching for subsidiary country, subsidiary 2-digit industry classification, parent country, and year in addition to (nearest neighbor) matching on parent and subsidiary sizes. Parents and subsidiaries located in a country experiencing an economic downturn are excluded from both treatment and control groups. Results are reported for the Subsidiary Investment ( $t$ ), defined as the change in fixed assets plus depreciation, normalized by lagged total assets, and Subsidiary Employment Growth ( $t$ ), defined as $\ln ($ employment $(\mathrm{t})$ / employment(t-1)) of the subsidiary. Subsidiary (Parent) Size is measured by the natural logarithm of the subsidiary (parent) total book assets. Parent Cash Flow is defined as its Operating profit/loss plus depreciation, over total assets. ATETs, reported in Columns (1) and (3) are bias adjusted by all these continuous control variables of interest. Regressions, reported in Columns (2) and (4), include match-pair fixed effects in all specifications. Errors are corrected for clustering of observations at the parent firm level. Symbols ${ }^{*},{ }^{* * * * *}$ denote significance at the $10 \%, 5 \%$, and $1 \%$ respectively.

Panel A. Only subsidiaries in countries that do not have a common border with the country experiencing an economic downturn

(1)

(2)

Subsidiary Investment Subsidiary
(2)

Matching

\begin{tabular}{l}
\hline Estimation Method \\
\hline ATET / Transmission Treatment \\
Dummy
\end{tabular}

Standard Errors
(3)

(4)

\begin{tabular}{|c|c|c|c|}
\hline \multirow{2}{*}{$\begin{array}{l}\text { Bias-adj Variables/Controls } \\
\text { Fixed Effects } \\
\end{array}$} & \multicolumn{3}{|c|}{$\begin{array}{l}\text { Subsidiary Size (t-1), Parent Size (t-1), } \\
\text { And Parent Cash Flow (t-1), Subsidiary Investment/ Employment Growth (t-1) }\end{array}$} \\
\hline & Match pair & & Match pair \\
\hline N (Matched Observations) & 11,370 & 10,488 & 10,488 \\
\hline$R^{2}$ & 0.580 & & 0.511 \\
\hline N (Firms) & 5,048 & & 4,638 \\
\hline N (Clusters/Parents) & 1,055 & & 987 \\
\hline
\end{tabular}


Panel B: U.S. Parents Excluded

(1) (2)

Subsidiary Investment Subsidiary Investment
(3)

Subsidiary

Employment Growth Employment Growth

Estimation Method

Matching

$-1.005^{* * *}$

Regression

$-0.615^{*}$

Matching

(0.349)

$(0.958)$

Dummy

Standard Errors

$(0.282)$

ubsidiary Size (t-1), Parent Size (t-1)

Bias-adj Variables/Controls

Parent Cash Flow (t-1), and Subsidiary Investment (t-1)/Employment Growth (t-1)

\begin{tabular}{l}
\hline Fixed Effects \\
$\mathrm{N}$ (Matched Observations) \\
$R^{2}$
\end{tabular}

$\mathrm{N}$ (Firms)

$\mathrm{N}$ (Clusters/Parents)

Match pair

6,064

6,064

0.593

2,644

634

5,082

5,082

0.522

2,230

536 
Panel C: Subsidiaries and their Parents are in the EU

(2)

(3)

(4)

Subsidiary Investment Subsidiary Investment Subsidiary Employment Subsidiary Employment

\begin{tabular}{|c|c|c|c|c|}
\hline & & & Growth & Growth \\
\hline Estimation Method & Matching & Regression & Matching & Regression \\
\hline $\begin{array}{l}\text { ATET / Propagation Treatment } \\
\text { Dummy }\end{array}$ & $-1.274 * * *$ & $-0.868 * *$ & $-2.526 * *$ & $-3.935 * * *$ \\
\hline Standard Errors & $(0.354)$ & $(0.481)$ & (1.131) & $(1.355)$ \\
\hline Bias-adj Variables/Controls & \multicolumn{4}{|c|}{$\begin{array}{c}\text { Subsidiary Size (t-1), Parent Size (t-1), } \\
\text { Parent Cash Flow (t-1), and Subsidiary Investment (t-1)/Employment Growth (t-1) }\end{array}$} \\
\hline Fixed Effects & & Match pair & & Match pair \\
\hline $\mathrm{N}$ (Matched Observations) & 4,532 & 4,532 & 3,826 & 3,826 \\
\hline$R^{2}$ & & 0.584 & & 0.518 \\
\hline N (Firms) & & 1,874 & & 1,565 \\
\hline $\mathrm{N}$ (Clusters/Parents) & & 421 & & 361 \\
\hline
\end{tabular}


Panel D: Subsidiaries and their Parents are in the Eurozone

(1)

(2)

(3)

(4)

Subsidiary Investment Subsidiary Investment Subsidiary Employment Subsidiary Employment

\begin{tabular}{|c|c|c|c|c|}
\hline & & & Growth & Growth \\
\hline Estimation Method & Matching & Regression & Matching & Regression \\
\hline $\begin{array}{l}\text { ATET / Propagation Treatment } \\
\text { Dummy }\end{array}$ & $-2.156^{* * *}$ & $-1.927 * *$ & -1.749 & -1.543 \\
\hline Standard Errors & $(0.6734)$ & $(0.742)$ & $(1.339)$ & $(1.142)$ \\
\hline Bias-adj Variables/Controls & \multicolumn{4}{|c|}{$\begin{array}{c}\text { Subsidiary Size (t-1), Parent Size (t-1), } \\
\text { Parent Cash Flow (t-1), and Subsidiary Investment (t-1)/Employment Growth (t-1) }\end{array}$} \\
\hline Fixed Effects & & Match pair & & Match pair \\
\hline N (Matched Observations) & 2,114 & 2,114 & 1,738 & 1,738 \\
\hline$R^{2}$ & & 0.589 & & 0.510 \\
\hline N (Firms) & & 811 & & 657 \\
\hline N (Clusters/Parents) & & 166 & & 130 \\
\hline
\end{tabular}


Panel E: U.S. Parents Only

(1)

(2)

(3)

(4)

Subsidiary Investment Subsidiary Investment Subsidiary Employment Subsidiary Employment

\begin{tabular}{|c|c|c|c|c|}
\hline & & & Growth & Growth \\
\hline Estimation Method & Matching & Regression & Matching & Regression \\
\hline $\begin{array}{l}\text { ATET / Propagation Treatment } \\
\text { Dummy }\end{array}$ & $-0.699 * * *$ & $-0.693 * * *$ & -1.273 & $-1.500^{*}$ \\
\hline Standard Errors & $(0.270)$ & $(0.256)$ & $(0.869)$ & $(0.842)$ \\
\hline Bias-adj Variables/Controls & \multicolumn{4}{|c|}{$\begin{array}{c}\text { Subsidiary Size (t-1), Parent Size (t-1), } \\
\text { Parent Cash Flow (t-1), and Subsidiary Investment (t-1)/Employment Growth (t-1) }\end{array}$} \\
\hline Fixed Effects & & Match pair & & Match pair \\
\hline $\mathrm{N}$ (Matched Observations) & 7,434 & 7,434 & 6,878 & 6,878 \\
\hline$R^{2}$ & & 0.584 & & 0.506 \\
\hline N (Firms) & & 2,967 & & 2,728 \\
\hline $\mathrm{N}$ (Clusters/Parents) & & 530 & & 510 \\
\hline
\end{tabular}




\section{Table OA-2 - Robustness - Subsamples and Alternative Specifications}

This table provides robustness tests for our main tests presented in Tables 3 and 5 in different subsamples. In Panels A and B, we report average treatment effect on the treated (ATET) in Columns (1) and (3) and regression estimates in Columns (2) and (4) with robust standard errors in the parentheses. In Panel $\mathrm{C}$, matching estimates are not different from those in the main analysis so only the regression estimates are provided. In constructing the Propagation Treatment Dummy variable, a parent is treated if it has a subsidiary in a country experiencing an economic downturn that year with the economic downturn defined as a real GDP growth at least two standard deviations less than the country's long-term average. To construct our control sample, we use Mahalanobis matching with exact matching for subsidiary country, subsidiary 2-digit industry classification, parent country, and year in addition to (nearest neighbor) matching on parent and subsidiary sizes. Parents and subsidiaries located in a country experiencing an economic downturn are excluded from both treatment and control groups. To construct our sample, we use Mahalanobis matching with exact matching for subsidiary country, subsidiary 2-digit industry classification, parent country, and year in addition to (nearest neighbor) matching on parent and subsidiary sizes. Results are reported for the Subsidiary Investment $(t)$, defined as the change in fixed assets plus depreciation, normalized by lagged total assets, and Subsidiary Employment Growth $(t)$, defined as $\ln ($ employment $(\mathrm{t}) /$ employment(t-1)) of the subsidiary. Subsidiary (Parent) Size is measured by the natural logarithm of the subsidiary (parent) total book assets. Parent Cash Flow is defined as its Operating profit/loss plus depreciation, over total assets. ATETs, reported in Columns (1) and (3) are bias adjusted by all these continuous control variables of interest. Regressions, reported in Columns (2) and (4), include match-pair fixed effects in all specifications. Errors are corrected for clustering of observations at the parent firm level. Symbols ${ }^{* * *},{ }^{* * *}$ denote significance at the $10 \%, 5 \%$, and $1 \%$ respectively.

\section{Panel A: Majority-Owned Subsidiaries}

(1)

$(2)$

(3)

(4)

Subsidiary Investment Subsidiary Investment Subsidiary Employment Subsidiary Employment

\begin{tabular}{lcccc} 
& & & Growth & Growth \\
\hline Estimation Method & Matching & Regression & Matching & Regression \\
\hline ATET / Propagation Treatment & $-1.138^{* * *}$ & $-1.012 * * *$ & -0.940 & -1.127 \\
$\begin{array}{l}\text { Dummy } \\
\text { Standard Errors }\end{array}$ & $(0.204)$ & $(0.242)$ & $(0.743)$ & $(0.757)$ \\
\hline
\end{tabular}

\begin{tabular}{lccc}
\hline Bias-adj Variables/Controls & \multicolumn{3}{c}{ Subsidiary Size (t-1), Parent Size (t-1), } \\
& Parent Cash Flow (t-1), and Subsidiary Investment (t-1)/Employment Growth (t-1) \\
\hline Fixed Effects & Match pair & Match pair \\
\hline N (Matched Observations) & 10,178 & 10,178 & 9,060 \\
$R^{2}$ & 0.583 & 0.519 \\
N (Firms) & 4,258 & 3,786 \\
N (Clusters/Parents) & 982 & 897 \\
\hline
\end{tabular}


$\underline{\text { Panel B: Controlling for Parent's Growth Opportunities }}$

\begin{tabular}{|c|c|c|c|c|}
\hline & $\begin{array}{c}\text { (1) } \\
\text { Subsidiary Investment }\end{array}$ & $\begin{array}{c}\text { (2) } \\
\text { Subsidiary Investment }\end{array}$ & $\begin{array}{c}(3) \\
\text { Subsidiary } \\
\text { Employment Growth }\end{array}$ & $\begin{array}{c}\text { (4) } \\
\text { Subsidiary } \\
\text { Employment Growth }\end{array}$ \\
\hline Estimation Method & Matching & Regression & Matching & Regression \\
\hline $\begin{array}{l}\text { ATET / Propagation } \\
\text { Treatment Dummy }\end{array}$ & $-0.883 * * *$ & $-0.779 * * *$ & $-1.295^{*}$ & $-1.679 * *$ \\
\hline Standard Errors & $(0.234)$ & $(0.235)$ & $(0.693)$ & $(0.724)$ \\
\hline Subsidiary Size (t-1) & & $\begin{array}{l}-0.049 \\
(0.188)\end{array}$ & & $\begin{array}{l}-0.504 \\
(0.524)\end{array}$ \\
\hline Parent Size (t-1) & & $\begin{array}{c}0.012 \\
(0.159)\end{array}$ & & $\begin{array}{c}0.572 \\
(0.498)\end{array}$ \\
\hline Parent Cash Flow (t-1) & & $\begin{array}{l}-2.034 \\
(2.407)\end{array}$ & & $\begin{array}{l}-10.672 \\
(8.387)\end{array}$ \\
\hline $\begin{array}{l}\text { Subsidiary Investment/ } \\
\text { Employment Growth (t-1) }\end{array}$ & & $\begin{array}{l}0.352 * * * \\
(0.036)\end{array}$ & & $\begin{array}{c}0.031 \\
(0.032)\end{array}$ \\
\hline Parent Q (t-1) & & $\begin{array}{l}0.429 * * * \\
(0.153)\end{array}$ & & $\begin{array}{l}1.582 * * * \\
(0.608)\end{array}$ \\
\hline Bias-adj Variables & $\begin{array}{r}\text { Subsidiary Size (t-1), } \\
\text { Cash Flow (t-1), Par } \\
\text { Investr }\end{array}$ & $\begin{array}{l}\text { rent Size (t-1), Parent } \\
\text { t Q (t-1), Subsidiary } \\
\text { nt ( } \mathrm{t}-1)\end{array}$ & $\begin{array}{r}\text { Subsidiary Size (t-1), } \\
\text { Cash Flow (t-1), Pa } \\
\text { Employ }\end{array}$ & $\begin{array}{l}\text { arent Size (t-1), Parent } \\
\text { at } \mathrm{Q}(\mathrm{t}-1) \text {, Subsidiary } \\
\text { ent }(\mathrm{t}-1)\end{array}$ \\
\hline Fixed Effects & & Match pair & & Match pair \\
\hline $\begin{array}{l}\mathrm{N} \text { (Matched Observations) } \\
R^{2} \\
\mathrm{~N} \text { (Firms) } \\
\mathrm{N} \text { (Clusters/Parents) }\end{array}$ & 10,742 & $\begin{array}{c}10,742 \\
0.582 \\
4,353 \\
790 \\
\end{array}$ & 9,922 & $\begin{array}{l}9,922 \\
0.511 \\
3,988 \\
763 \\
\end{array}$ \\
\hline
\end{tabular}


$\underline{\text { Panel C: Size-Weighted Estimation }}$

(1)

(2)

Subsidiary Investment Subsidiary Employment Growth

\begin{tabular}{lcc}
\hline Estimation Method: Regression & & \\
\hline Propagation Treatment Dummy & $-0.648^{* * *}$ & $-2.122 * * *$ \\
Standard Errors & $(0.209)$ & $(0.685)$ \\
& & \\
Controls & Subsidiary Size (t-1), Parent Size (t-1), \\
& Parent Cash Flow (t-1), and Subsidiary Investment \\
& $(\mathrm{t}-1) /$ Employment Growth (t-1) \\
\hline Fixed Effects & Match pair & Match pair \\
\hline N (Matched Observations) & 13,498 & 11,960 \\
$R^{2}$ (Firms) & 0.593 & 0.525 \\
$\mathrm{~N}$ (Clusters/Parents) & 5,600 & 4,943 \\
\hline
\end{tabular}




\section{Panel D: Randomized Inference Test}

This table repeats our main tests presented in Tables 3 and 5 in subsamples when the significance of the estimates is assessed using a randomized inference test described in Section 5. The empirical standard error is computed as the standard deviation of the 1,000 estimated coefficients and empirical p-value as the percentile that the coefficient obtained using our original sample has in the empirical distribution of the 1,000 estimated coefficients. ATETs, reported in Columns (1) and (3) are bias adjusted by all the continuous control variables of interest. Regressions, reported in Columns (2) and (4), include match-pair fixed effects in all specifications. Symbols ${ }^{* * * * * *}$, denote significance at the $10 \%, 5 \%$, and $1 \%$ respectively.

(1)

(2)

(3)

(4)

Subsidiary Investment Subsidiary Investment Subsidiary Employment Subsidiary Employment

\begin{tabular}{lcccc} 
& & & Growth & Growth \\
\hline Estimation Method & Matching & Regression & Matching & Regression \\
\hline ATET / Propagation Treatment & $-0.989^{* * *}$ & $-0.710^{* *}$ & $-1.542^{*}$ & $-2.175^{* *}$ \\
Dummy & & & $(0.883)$ & $(0.842)$ \\
Empirical Standard Error & $(0.206)$ & $(0.201)$ & 0.092 & 0.024 \\
Empirical p-value & 0.006 & 0.031 & \\
Bias-adj Variables/Controls & Subsidiary Size (t-1), Parent Size (t-1), Parent Cash Flow (t-1), and Subsidiary Investment/ \\
& \multicolumn{2}{c}{ Employment Growth (t-1) } \\
\hline Fixed Effects & \multicolumn{2}{c}{ Match pair } & Match pair \\
\hline
\end{tabular}


Panel E: Double Clustering the Standard Errors at the Parent and Parent Country-Year Levels

This table repeats our main tests presented in Tables 3 and 5 with standard errors robust to double clustering of observations at parent and the parent country-year levels.

\begin{tabular}{|c|c|c|c|c|}
\hline & $\begin{array}{c}(1) \\
\text { Subsidiary Investment }\end{array}$ & $\begin{array}{c}(2) \\
\text { Subsidiary Investment }\end{array}$ & $\begin{array}{l}(3) \\
\text { Subsidiary Employment } \\
\text { Growth }\end{array}$ & $\begin{array}{c}\text { (4) } \\
\text { Subsidiary Employment } \\
\text { Growth }\end{array}$ \\
\hline Estimation Method & Regression & Regression & Regression & Regression \\
\hline Propagation Treatment Dummy & $\begin{array}{c}-0.854 * * * \\
(0.232)\end{array}$ & $\begin{array}{l}-0.710^{* * *} \\
(0.198)\end{array}$ & $\begin{array}{c}-1.675^{* * *} \\
(0.501)\end{array}$ & $\begin{array}{c}-2.175^{* * *} \\
(0.607)\end{array}$ \\
\hline Subsidiary Size (t-1) & & $\begin{array}{c}0.007 \\
(0.175)\end{array}$ & & $\begin{array}{l}-0.157 \\
(0.495)\end{array}$ \\
\hline Parent Size (t-1) & & $\begin{array}{l}-0.049 \\
(0.131)\end{array}$ & & $\begin{array}{c}0.539 \\
(0.421)\end{array}$ \\
\hline Parent Cash Flow (t-1) & & $\begin{array}{l}3.256 \\
(2.091)\end{array}$ & & $\begin{array}{c}7.373 \\
(6.539)\end{array}$ \\
\hline $\begin{array}{l}\text { Subsidiary Investment / Empl. } \\
\text { Growth }(\mathrm{t}-1)\end{array}$ & & $\begin{array}{c}0.348 * * * \\
(0.029)\end{array}$ & & $\begin{array}{l}0.053^{*} \\
(0.030)\end{array}$ \\
\hline Fixed Effects & Match pair & Match pair & Match pair & Match pair \\
\hline $\mathrm{N}$ (Matched Observations) & 13,498 & 13,498 & 11,960 & 11,960 \\
\hline$R^{2}$ & 0.538 & 0.588 & 0.510 & 0.511 \\
\hline N (Firms) & 5,600 & 5,600 & 4,943 & 4,943 \\
\hline N (Parent Country-Year) & 41 & 41 & 39 & 39 \\
\hline
\end{tabular}




\section{Table OA-3 - Difference-in-Differences Estimates}

This table provides the results of Difference-in Differences estimates (regressions (1) and (2)) and the pre-trend analysis (regressions (3) and (4)) for our main results. Event Year is an indicator that takes the value of one in the year the parent treated; Pre-Event Year is one in the previous year. The sample for regressions (3) and (4) includes only the parent that were not also treated in previous two years before the event year to allow a pre-trend analysis. In constructing the Propagation Treatment dummy variable, a parent is treated if it has a subsidiary in a country experiencing an economic downturn that year with the economic downturn defined as a real GDP growth less than the country's long-term average at different thresholds. To construct our control sample, we use Mahalanobis matching with exact matching for subsidiary country, subsidiary 2-digit industry classification, parent country, and year in addition to (nearest neighbor) matching on parent and subsidiary sizes as of two years before the event year. Parents and subsidiaries located in a country experiencing an economic downturn are excluded from both treatment and control groups. Results are reported for the Subsidiary Investment ( $t$ ), defined as the change in fixed assets plus depreciation, normalized by lagged total assets, and in percentage points, Subsidiary Employment Growth $(t)$, defined as $\ln ($ employment(t) / employment(t-1)) of the subsidiary. Subsidiary (Parent) Size is measured by the natural logarithm of the subsidiary (parent) total book assets. Parent Cash Flow is defined as its Operating profit/loss plus depreciation, over total assets. Regressions also include match-pair fixed effects in all specifications. Errors are corrected for clustering of observations at the parent firm level. Symbols ${ }^{* * *},{ }^{* * *}$ denote significance at the $10 \%, 5 \%$, and $1 \%$ respectively. 


\begin{tabular}{|c|c|c|c|c|}
\hline & $\begin{array}{c}\text { (1) } \\
\text { Subsidiary } \\
\text { Investment }(\mathrm{t})\end{array}$ & $\begin{array}{l}\text { (2) } \\
\text { Subsidiary } \\
\text { Employment } \\
\text { Growth (t) }\end{array}$ & $\begin{array}{c}(3) \\
\text { Subsidiary } \\
\text { Investment }(\mathrm{t}-1)\end{array}$ & $\begin{array}{c}\text { (4) } \\
\text { Subsidiary } \\
\text { Employment } \\
\text { Growth (t-1) }\end{array}$ \\
\hline $\begin{array}{l}\text { Propagation Treatment } \times \\
\text { Event Year }\end{array}$ & $\begin{array}{c}-0.668 * * * \\
(0.226)\end{array}$ & $\begin{array}{l}-1.475^{*} \\
(0.785)\end{array}$ & & \\
\hline Subsidiary Size (t-1) & $\begin{array}{c}-4.044 * * * \\
(0.483)\end{array}$ & $\begin{array}{l}-2.683 \\
(1.915)\end{array}$ & & \\
\hline Parent Size (t-1) & $\begin{array}{l}-0.337 \\
(0.725)\end{array}$ & $\begin{array}{l}-0.570 \\
(2.663)\end{array}$ & & \\
\hline Parent Cash Flow (t-1) & $\begin{array}{l}-0.574 \\
(2.771)\end{array}$ & $\begin{array}{l}15.305 \\
(9.297)\end{array}$ & & \\
\hline $\begin{array}{l}\text { Propagation Treatment } \times \\
\text { Pre-Event Year }\end{array}$ & & & $\begin{array}{r}0.178 \\
(0.239)\end{array}$ & $\begin{array}{r}1.463 \\
(1.128)\end{array}$ \\
\hline Subsidiary Size (t-2) & & & $\begin{array}{l}-4.174 * * * \\
(0.596)\end{array}$ & $\begin{array}{c}-6.366^{* *} \\
(2.870)\end{array}$ \\
\hline Parent Size (t-2) & & & $\begin{array}{c}0.371 \\
(0.923)\end{array}$ & $\begin{array}{c}1.937 \\
(3.859)\end{array}$ \\
\hline Parent Cash Flow (t-2) & & & $\begin{array}{l}-1.209 \\
(3.253)\end{array}$ & $\begin{array}{c}4.172 \\
(15.134)\end{array}$ \\
\hline $\begin{array}{l}\text { Nearest Neighborhood } \\
\text { Mahalanobis matching }\end{array}$ & \multicolumn{4}{|c|}{$\begin{array}{l}\text { Subsidiary Size }(\mathrm{t}-2) \text {, Parent Size }(\mathrm{t}-2) \\
\text { (in addition to the exact match variables) }\end{array}$} \\
\hline Sample & \multicolumn{2}{|c|}{ Full Matched Sample } & \multicolumn{2}{|c|}{$\begin{array}{l}\text { Matched Sample with "No } \\
\text { Treatment in Previous Two } \\
\text { Years" Filter }\end{array}$} \\
\hline $\mathrm{N}$ (Matched Observations) & 10,200 & 9,562 & 5,558 & 4,900 \\
\hline$R^{2}$ & 0.531 & 0.508 & 0.531 & 0.486 \\
\hline $\mathrm{N}$ (Firms) & 4,302 & 3,914 & 3,562 & 3,135 \\
\hline N (Clusters/Parents) & 969 & 886 & 885 & 807 \\
\hline
\end{tabular}


Table OA-4 - Matching Estimates for Changes in Subsidiary Investment and Employment Growth

Table reports average treatment effect on the treated (ATET) with Abadie-Imbens (AI) robust standard errors in the parentheses. In constructing the Propagation Treatment Dummy variable, a parent is treated if it has a subsidiary in a country experiencing an economic downturn that year with the economic downturn defined as a real GDP growth at least two standard deviations less than the country's long-term average. To construct our control sample, we use Mahalanobis matching with exact matching for subsidiary country, subsidiary 2-digit industry classification, parent country, and year in addition to (nearest neighbor) matching on parent and subsidiary sizes. Parents and subsidiaries located in a country experiencing an economic downturn are excluded from both treatment and control groups. The statistic is calculated for the change in subsidiary investment from (t-1) to $t$, where subsidiary investment is defined as the change in fixed assets plus depreciation, normalized by lagged total assets. Subsidiary (Parent) Size is measured by the natural logarithm of the subsidiary (parent) total book assets. Parent Cash Flow is defined as its Operating profit/loss plus depreciation, over total assets. ATET is bias-adjusted by using subsidiary and parent sizes in Columns (1) and (3) and then by all these continuous control variables of interest in Columns (2) and (4). All outcome variables are trimmed at the upper and lower 5\% level. All control variables are winsorized at the upper and lower $1 \%$ level and are included in the tests with one lag. Symbols ${ }^{* * * * * *}$ denote significance at the $10 \%, 5 \%$, and $1 \%$ respectively.

\begin{tabular}{|c|c|c|c|c|}
\hline & $\begin{array}{l}\text { (1) } \\
\text { Change in Subsidiary } \\
\text { Investment } \\
(\text { from }(\mathrm{t}-1) \text { to }(\mathrm{t}))\end{array}$ & $\begin{array}{c}\text { (2) } \\
\text { Change in Subsidiary } \\
\text { Investment } \\
(\text { from }(\mathrm{t}-1) \text { to }(\mathrm{t}))\end{array}$ & $\begin{array}{c}\text { (3) } \\
\text { Change in } \\
\text { Subsidiary } \\
\text { Employment } \\
\text { Growth } \\
\text { (from }(\mathrm{t}-1) \text { to }(\mathrm{t}))\end{array}$ & $\begin{array}{l}(4) \\
\text { Change in Subsidiary } \\
\text { Employment Growth } \\
(\text { from }(\mathrm{t}-1) \text { to }(\mathrm{t}))\end{array}$ \\
\hline Estimation Method & Matching & Matching & Matching & Matching \\
\hline $\begin{array}{l}\text { ATET / Propagation Treatment } \\
\text { Dummy }\end{array}$ & $-0.451 * *$ & $-0.460 * *$ & $-1.890 * *$ & $-1.746^{* *}$ \\
\hline Abadie-Imbens robust std. err. & $(0.216)$ & $(0.216)$ & $(0.827)$ & $(0.827)$ \\
\hline Bias-adj Variables/Controls & $\begin{array}{l}\text { Subsidiary Size }(\mathrm{t}-1) \\
\text { Parent Size }(\mathrm{t}-1)\end{array}$ & $\begin{array}{c}\text { Subsidiary Size (t-1), } \\
\text { Parent Size (t-1), Parent } \\
\text { Cash Flow (t-1) }\end{array}$ & $\begin{array}{l}\text { Subsidiary Size }(\mathrm{t}-1) \\
\text { Parent Size }(\mathrm{t}-1)\end{array}$ & $\begin{array}{l}\text { Subsidiary Size (t-1), } \\
\text { Parent Size (t-1), Parent } \\
\text { Cash Flow (t-1) }\end{array}$ \\
\hline N (Matched Observations) & 13,498 & 13,498 & 11,960 & 11,960 \\
\hline
\end{tabular}




\section{Table OA-5 - Robustness - Alternative Matching}

This table provides robustness tests for our main tests presented in Tables 3 and 5 to different matching metrics. In Panels A and B, we report average treatment effect on the treated (ATET) in Columns (1) and (3) and regression estimates in Columns (2) and (4) with robust standard errors in the parentheses. In constructing the Propagation Treatment Dummy variable, a parent is treated if it has a subsidiary in a country experiencing an economic downturn that year with the economic downturn defined as a real GDP growth at least two standard deviations less than the country's long-term average. To construct our sample, we use Mahalanobis matching with exact matching for subsidiary country, subsidiary 2-digit industry classification, parent country, and year in addition to (nearest neighbor) matching on our continuous variables of interest in Panels A and B as well as Coarsened Exact Matching in Panel C. Linearized Propensity Scores (LPS) in Panel B are calculated as the natural logarithm of the ratio of the estimated propensity score over (1-estimated propensity score), running a logistic regression of Propagation Treatment Dummy on Subsidiary Size (t-1), Parent Size (t-1), Parent Cash Flow (t-1), and Subsidiary Investment (t-1)/Employment Growth (t-1). Results are reported for the Subsidiary Investment $(t)$, defined as the change in fixed assets plus depreciation, normalized by lagged total assets, and Subsidiary Employment Growth ( $t$ ), defined as $\ln ($ employment(t) / employment(t-1)) of the subsidiary. Subsidiary (Parent) Size is measured by the natural logarithm of the subsidiary (parent) total book assets. Parent Cash Flow is defined as its Operating profit/loss plus depreciation, over total assets. ATETs, reported in Columns (1) and (3) are bias adjusted by all these continuous control variables of interest. Regressions, reported in Columns (2) and (4), include match-pair fixed effects in all regressions in Panels A and B. All regressions include strata fixed effects in Panel C. Errors are corrected for clustering of observations at the parent firm level. Symbols ${ }^{* * *},{ }^{* * *}$ denote significance at the $10 \%, 5 \%$, and $1 \%$ respectively.

Panel A: Mahalanobis Matching using All Control Variables

(1)

Subsidiary Investment Subsidiary Investment Subsidiary Employment Subsidiary Employment

\begin{tabular}{|c|c|c|c|c|}
\hline & & & Growth & Growth \\
\hline Estimation Method & Matching & Regression & Matching & Regression \\
\hline ATET / Propagation Treatment & $-0.950 * * *$ & $-0.541 * * *$ & $-2.407 * * *$ & $-2.609 * * *$ \\
\hline Dummy & & & & \\
\hline Standard Errors & $(0.167)$ & $(0.201)$ & $(0.620)$ & $(0.682)$ \\
\hline Bias-adj Variables/Controls & \multicolumn{4}{|c|}{$\begin{array}{l}\text { Subsidiary Size (t-1), Parent Size (t-1), } \\
\text { Parent Cash Flow (t-1), and Subsidiary Investment (t-1)/Employment Growth (t-1) }\end{array}$} \\
\hline Fixed Effects & & Match pair & & Match pair \\
\hline $\mathrm{N}$ (Matched Observations) & 13,498 & 13,498 & 11,960 & 11,960 \\
\hline$R^{2}$ & & 0.565 & & 0.528 \\
\hline $\mathrm{N}$ (Firms) & & 5,737 & & 5,057 \\
\hline $\mathrm{N}$ (Clusters/Parents) & & 1,189 & & 1,076 \\
\hline
\end{tabular}


$\underline{\text { Panel B: Mahalanobis Matching using Linearized Propensity Scores }}$

(1)

Subsidiary Investment
(2)

Subsidiary Investment
(3)

Subsidiary

Employment Growth Matching $-1.234 *$

$(0.739)$

$(0.216)$

Subsidiary Size (t-1), Parent Size (t-1)

Bias-adj Variables/Controls

$(0.235)$

Regression

$-0.803 * * *$

Parent Cash Flow (t-1), and Subsidiary Investment (t-1)/Employment Growth (t-1)

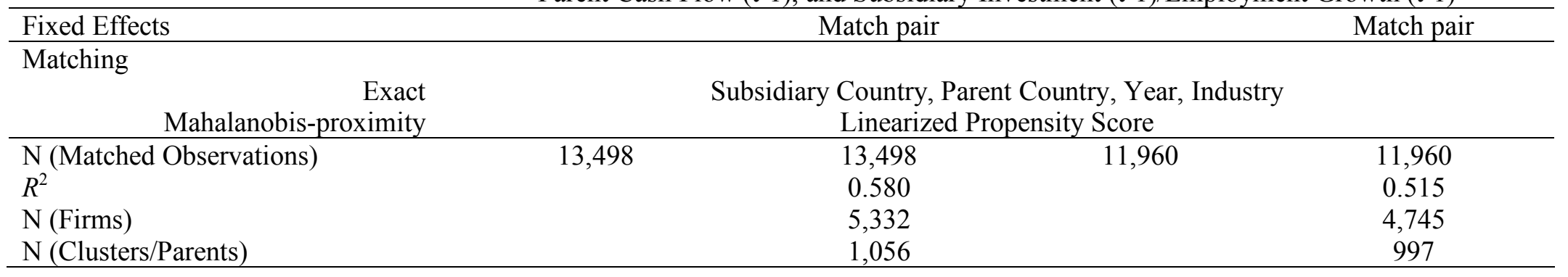

(4)

Subsidiary

Employment Growth

Regression

$-1.655 * * *$

$(0.634)$
4,745 
Panel C: Coarsened Exact Matching

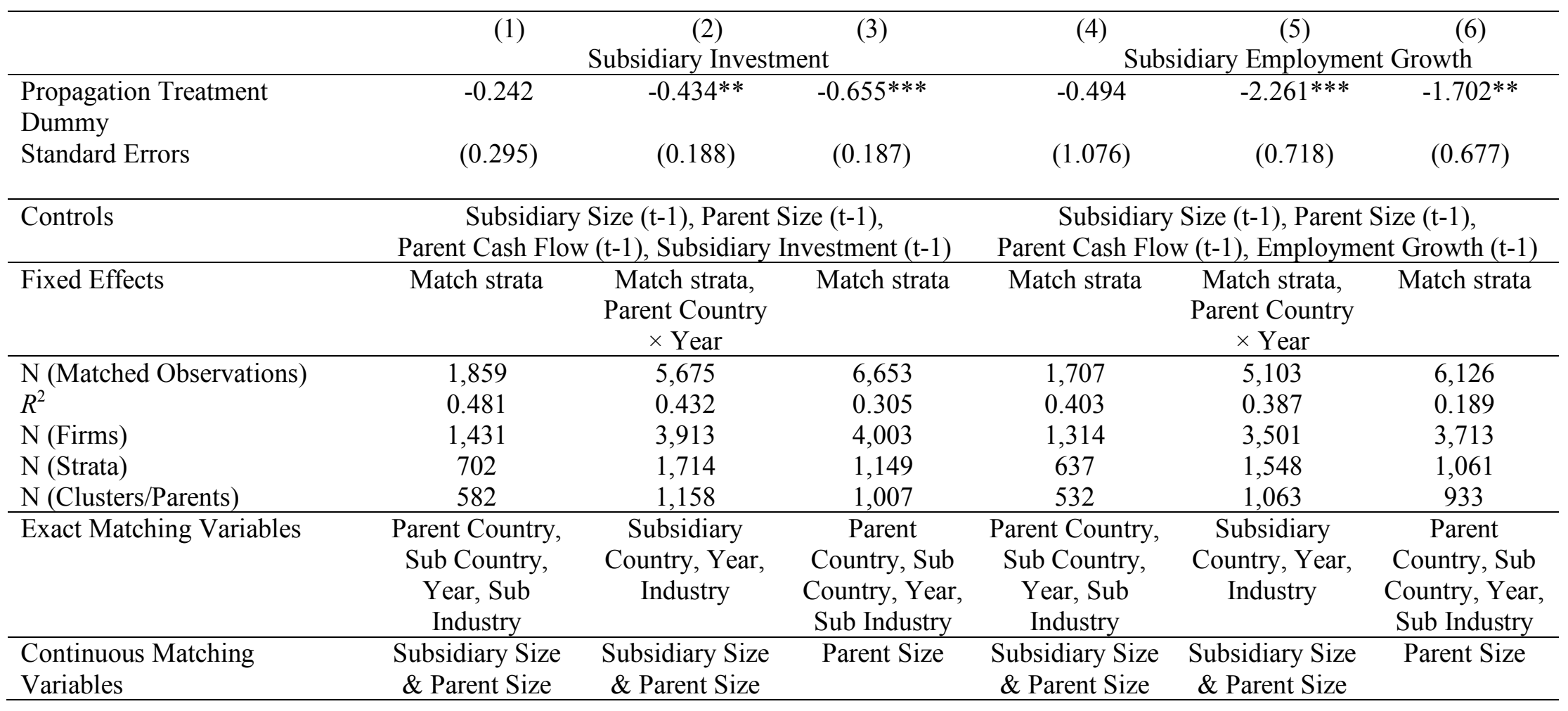


Table OA-6 Robustness - Impact of the International Propagation on Destination Economies

Table reports regression estimates analogous to those presented in Table 9 except that we use standard errors (reported in parentheses) robust to double clustering at the country and industry level. Symbols ${ }^{* * *},{ }^{* * *}$ denote significance at the $10 \%, 5 \%$, and $1 \%$ level respectively.
(1)
(2)
(3)
(4)
(5)
(6)
(7)
(8)

Propagation Share

Ln(Sales) Ln(Sales) Ln(Sales)

\begin{tabular}{ccccccccc}
$(0.157)$ & $(0.192)$ & $(0.216)$ & $(0.215)$ & $(0.174)$ & $(0.215)$ & $(0.273)$ & $(0.271)$ \\
& & & & & & $0.170^{* * *}$ & $0.184 * * *$ \\
& & $0.162^{* * *}$ & $0.166^{* * *}$ & & & $(0.021)$ & $(0.022)$ \\
& & $(0.018)$ & $(0.018)$ & & & & $-3.798^{* * *}$ \\
& & & & & & & $(0.431)$ \\
& & & $-0.454^{* *}$ & & & & \\
& & & $(0.201)$ & & & No & No \\
Yes & No & No & No & Yes & No & No \\
No & Yes & Yes & Yes & No & Yes & Yes & Yes \\
4,477 & 4,466 & 3,091 & 3,091 & 4,541 & 4,528 & 3,012 & 3,012 \\
0.802 & 0.790 & 0.839 & 0.841 & 0.795 & 0.783 & 0.834 & 0.839 \\
\hline
\end{tabular}

$\operatorname{Ln}($ Size of Foreign Subsidiaries)

Share of Subsidiaries whose Parent Firms

Reside in Countries with an economic downturn

$-0.454^{*}$

$(0.431)$

\begin{tabular}{lcccccccc}
\hline Country, Industry, and Year FEs & Yes & No & No & No & Yes & \multicolumn{2}{c}{$\begin{array}{c}\text { No } \\
\text { No }\end{array}$} & $\begin{array}{c}\text { No } \\
\text { Yes }\end{array}$ \\
Country-year and Industry-year FEs & No & Yes & Yes & Yes & No & Yes \\
\hline N (Observations) & 4,477 & 4,466 & 3,091 & 3,091 & 4,541 & 4,528 & 3,012 & 3,012 \\
$R^{2}$ & 0.802 & 0.790 & 0.839 & 0.841 & 0.795 & 0.783 & 0.834 & 0.839 \\
\hline
\end{tabular}




\section{Table OA-7 Subsample Analysis of Rated and Non-Rated Parent Firms}

This table repeats our main tests presented in Tables 3 and 5 in subsamples restricted to U.S. parents that have no credit rating (Panel A) and have one (Panel B) respectively. We report average treatment effect on the treated (ATET) in Columns (1) and (3) and regression estimates in Columns (2) and (4) with robust standard errors in the parentheses. In constructing the Propagation Treatment Dummy variable, a parent is treated if it has a subsidiary in a country experiencing an economic downturn that year with the economic downturn defined as a real GDP growth at least two standard deviations less than the country's long-term average. To construct our control sample, we use Mahalanobis matching with exact matching for subsidiary country, subsidiary 2-digit industry classification, parent country, and year in addition to (nearest neighbor) matching on parent and subsidiary sizes. Parents and subsidiaries located in a country experiencing an economic downturn are excluded from both treatment and control groups. Results are reported for the Subsidiary Investment $(t-1)$, defined as the change in fixed assets plus depreciation, normalized by lagged total assets, and Subsidiary Employment Growth ( $t-1)$, defined as $\ln ($ employment(t-1) / employment(t-2)) of the subsidiary. Subsidiary (Parent) Size is measured by the natural logarithm of the subsidiary (parent) total book assets. Parent Cash Flow is defined as its Operating profit/loss plus depreciation, over total assets. ATETs, reported in Columns (1) and (3) are bias adjusted by all the continuous control variables of interest. Regressions, reported in Columns (2) and (4), include match-pair fixed effects in all specifications. Errors are corrected for clustering of observations at the parent firm level. Symbols ${ }^{*},{ }^{* *},{ }^{* * *}$ denote significance at the $10 \%, 5 \%$, and $1 \%$ respectively.

Panel A. Unrated U.S. Parents

(1)

(2)

(3)

(4)

Subsidiary Investment Subsidiary Investment Subsidiary Employment Subsidiary Employment

\begin{tabular}{|c|c|c|c|c|}
\hline & & & Growth & Growth \\
\hline Estimation Method & Matching & Regression & Matching & Regression \\
\hline $\begin{array}{l}\text { ATET / Propagation Treatment } \\
\text { Dummy }\end{array}$ & $-1.510 * *$ & $-1.363 * *$ & $-6.705 * * *$ & $-3.839^{*}$ \\
\hline Standard Errors & $(0.639)$ & $(0.584)$ & $(1.769)$ & $(1.990)$ \\
\hline Bias-adj Variables/Controls & \multicolumn{4}{|c|}{$\begin{array}{l}\text { Subsidiary Size (t-1), Parent Size (t-1), Parent Cash Flow (t-1), and Subsidiary Investment/ } \\
\text { Employment Growth (t-1) }\end{array}$} \\
\hline Fixed Effects & & Match pair & & Match pair \\
\hline $\mathrm{N}$ (Matched Observations) & 694 & 694 & 598 & 598 \\
\hline$R^{2}$ & & 0.548 & & 0.537 \\
\hline N (Firms) & & 450 & & 381 \\
\hline $\mathrm{N}$ (Clusters/Parents) & & 201 & & 190 \\
\hline
\end{tabular}


$\underline{\text { Panel B. Rated U.S. Parents }}$

$$
\text { (1) }
$$

(2)

(3)

(4)

Subsidiary Investment Subsidiary Investment Subsidiary Employment Subsidiary Employment

\begin{tabular}{llccc} 
& & & Growth & Growth \\
\hline Estimation Method & Matching & Regression & Matching & Regression \\
\hline $\begin{array}{l}\text { ATET / Propagation Treatment } \\
\text { Dummy }\end{array}$ & $-0.517^{*}$ & -0.281 & -0.798 & -0.549 \\
Standard Errors & $(0.300)$ & $(0.278)$ & $(0.966)$ & $(0.882)$
\end{tabular}

\begin{tabular}{lccc}
\hline Bias-adj Variables/Controls & Subsidiary Size (t-1), Parent Size (t-1), Parent Cash Flow (t-1), and Subsidiary Investment/ Employment \\
& & Match pair & Match pair \\
\hline Fixed Effects & & 5,446 & 5,118 \\
\hline N (Matched Observations) & 5,446 & 0.572 & 0.506 \\
$R^{2}$ & & 2,090 & 1,941 \\
N (Firms) & & 283 & 272 \\
N (Clusters/Parents) & & & 2718 \\
\hline
\end{tabular}


Table OA-8 - Subsidiaries in Downturn Countries Around the Downturn Year

This table provides regression estimates for investment rate and employment growth for the subsidiaries in downturn countries before, during, and after the year of economic downturn relative to matched control subsidiaries. The sample is constructed by matching the subsidiaries in downturn countries by exact match of industry, parent country, and year in addition to the Mahalanobis nearest neighbor match based on subsidiary and parent size. Subsidiaries of whose parents are themselves located in a country experiencing an economic downturn are excluded from the sample. The economic downturn is defined as a real GDP growth at least two standard deviations less than the country's long-term average. In regression (3), the sample is restricted to the subsidiaries that were eligible to be a control observation in the previous two years before the main treatment event. Results are reported for the Subsidiary Investment, defined as the change in fixed assets plus depreciation, normalized by lagged total assets and in percentage points, in Columns (1)-(3) and for the Subsidiary Employment Growth, defined as the natural logarithm of the employment over lagged employment of the subsidiary Columns (4)-(6). Subsidiary (Parent) Size is measured by the natural logarithm of the subsidiary (parent) total book assets. Parent Cash Flow is defined as its Operating profit/loss plus depreciation, over total assets. Standard errors are in parentheses and are corrected for clustering of observations at the parent firm level. Symbols *, ${ }^{* *},{ }^{* * *}$ denote significance at the $10 \%, 5 \%$, and $1 \%$ respectively.

Panel A. Subsidiary Investment

\begin{tabular}{|c|c|c|c|}
\hline & $\begin{array}{c}(1) \\
\text { Subsidiary } \\
\text { Investment }(\mathrm{t})\end{array}$ & $\begin{array}{c}(2) \\
\text { Subsidiary } \\
\text { Investment }(\mathrm{t}+1)\end{array}$ & $\begin{array}{c}\text { (3) } \\
\text { Subsidiary } \\
\text { Investment (t-1) }\end{array}$ \\
\hline Subs in Crisis & $\begin{array}{c}-2.013 * * * \\
(0.507)\end{array}$ & $\begin{array}{c}-1.074 \\
(0.857)\end{array}$ & $\begin{array}{l}-0.761 \\
(0.476)\end{array}$ \\
\hline Subsidiary Size (t-1) & $\begin{array}{c}0.338 \\
(0.456)\end{array}$ & $\begin{array}{c}1.279 \\
(1.029)\end{array}$ & $\begin{array}{l}-0.535 \\
(0.404)\end{array}$ \\
\hline Parent Size (t-1) & $\begin{array}{c}0.324 \\
(0.310)\end{array}$ & $\begin{array}{l}-0.646 \\
(0.644)\end{array}$ & $\begin{array}{c}0.295 \\
(0.264)\end{array}$ \\
\hline Parent Cash Flow (t-1) & $\begin{array}{l}7.346 * * \\
(2.867)\end{array}$ & $\begin{array}{c}2.074 \\
(6.414)\end{array}$ & $\begin{array}{l}6.592 * \\
(3.371)\end{array}$ \\
\hline Constant & $\begin{array}{l}-0.075 \\
(2.574)\end{array}$ & $\begin{array}{c}5.690 \\
(5.023)\end{array}$ & $\begin{array}{l}2.190 \\
(2.190)\end{array}$ \\
\hline Fixed Effects & Match Pair & Match Pair & Match Pair \\
\hline Exact Matching & \multicolumn{3}{|c|}{ Parent Country, Year, Industry } \\
\hline $\begin{array}{l}\text { Nearest Neighborhood } \\
\text { Mahalanobis Matching }\end{array}$ & \multicolumn{3}{|c|}{ Subsidiary Size (t-1), Parent Size (t-1) } \\
\hline Sample & Full M & Sample & $\begin{array}{l}\text { Matched Sample } \\
\text { with "No Crisis } \\
\text { Last Year" Filter }\end{array}$ \\
\hline N (Matched Observations) & 3204 & 492 & 2750 \\
\hline$R^{2}$ & 0.514 & 0.639 & 0.503 \\
\hline N (Firms) & 2,012 & 329 & 1,918 \\
\hline $\mathrm{N}$ (Clusters/Parents) & 1,003 & 223 & 988 \\
\hline
\end{tabular}


Panel B. Subsidiary Employment Growth

\begin{tabular}{|c|c|c|c|}
\hline & $\begin{array}{c}(1) \\
\text { Subsidiary } \\
\text { Employment } \\
\text { Growth (t) }\end{array}$ & $\begin{array}{c}(2) \\
\text { Subsidiary } \\
\text { Employment } \\
\text { Growth }(\mathrm{t}+1)\end{array}$ & $\begin{array}{c}(3) \\
\text { Subsidiary } \\
\text { Employment } \\
\text { Growth (t-1) }\end{array}$ \\
\hline Subs in Crisis & $\begin{array}{c}-1.818 * \\
(1.022)\end{array}$ & $\begin{array}{c}-4.841 * \\
(2.540)\end{array}$ & $\begin{array}{c}0.801 \\
(1.164)\end{array}$ \\
\hline Subsidiary Size (t-1) & $\begin{array}{c}1.658 \\
(1.688)\end{array}$ & $\begin{array}{c}5.653 \\
(5.537)\end{array}$ & $\begin{array}{c}1.272 \\
(1.223)\end{array}$ \\
\hline Parent Size $(\mathrm{t}-1)$ & $\begin{array}{l}-1.055^{*} \\
(0.607)\end{array}$ & $\begin{array}{l}-0.999 \\
(2.297)\end{array}$ & $\begin{array}{l}-0.763 \\
(0.656)\end{array}$ \\
\hline Parent Cash Flow (t-1) & $\begin{array}{c}4.504 \\
(7.960)\end{array}$ & $\begin{array}{c}22.041 \\
(16.533)\end{array}$ & $\begin{array}{c}0.197 \\
(10.097)\end{array}$ \\
\hline Constant & $\begin{array}{c}5.255 \\
(5.673) \\
\end{array}$ & $\begin{array}{c}-9.581 \\
(18.348) \\
\end{array}$ & $\begin{array}{c}5.152 \\
(4.602) \\
\end{array}$ \\
\hline Fixed Effects & Match Pair & Match Pair & Match Pair \\
\hline Exact Matching & \multicolumn{3}{|c|}{ Parent Country, Year, Industry } \\
\hline $\begin{array}{l}\text { Nearest Neighborhood } \\
\text { Mahalanobis matching }\end{array}$ & \multicolumn{3}{|c|}{ Subsidiary Size (t-1), Parent Size (t-1) } \\
\hline Sample & Full M & Sample & $\begin{array}{l}\text { Matched Sample } \\
\text { with "No Crisis } \\
\text { Last Year" Filter }\end{array}$ \\
\hline $\begin{array}{l}\mathrm{N} \text { (Matched } \\
\text { Observations) }\end{array}$ & 3,178 & 643 & 2,784 \\
\hline$R^{2}$ & 0.506 & 0.668 & 0.487 \\
\hline N (Firms) & 2,004 & 451 & 1,921 \\
\hline $\mathrm{N}$ (Clusters/Parents) & 972 & 281 & 957 \\
\hline
\end{tabular}


Figure OA-1 U.S. Parent Firms in our Sample versus Compustat Firms

$\underline{\text { Panel A: Parent Firm Size }}$

$$
\text { Log(Sales): 2004-2006 }
$$

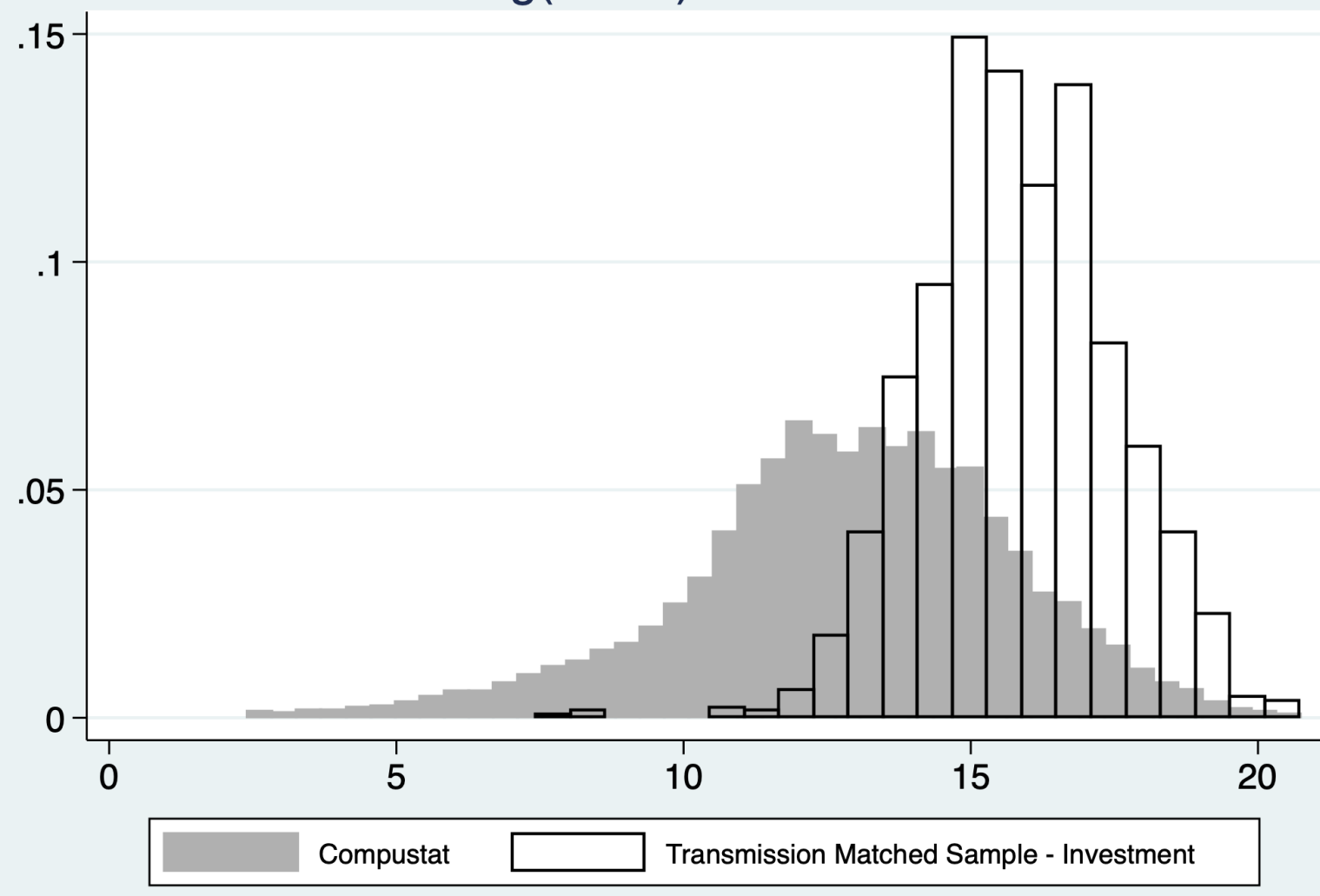


Panel B: Parent Firm Cash Holdings

Cash / Assets: 2004-2006

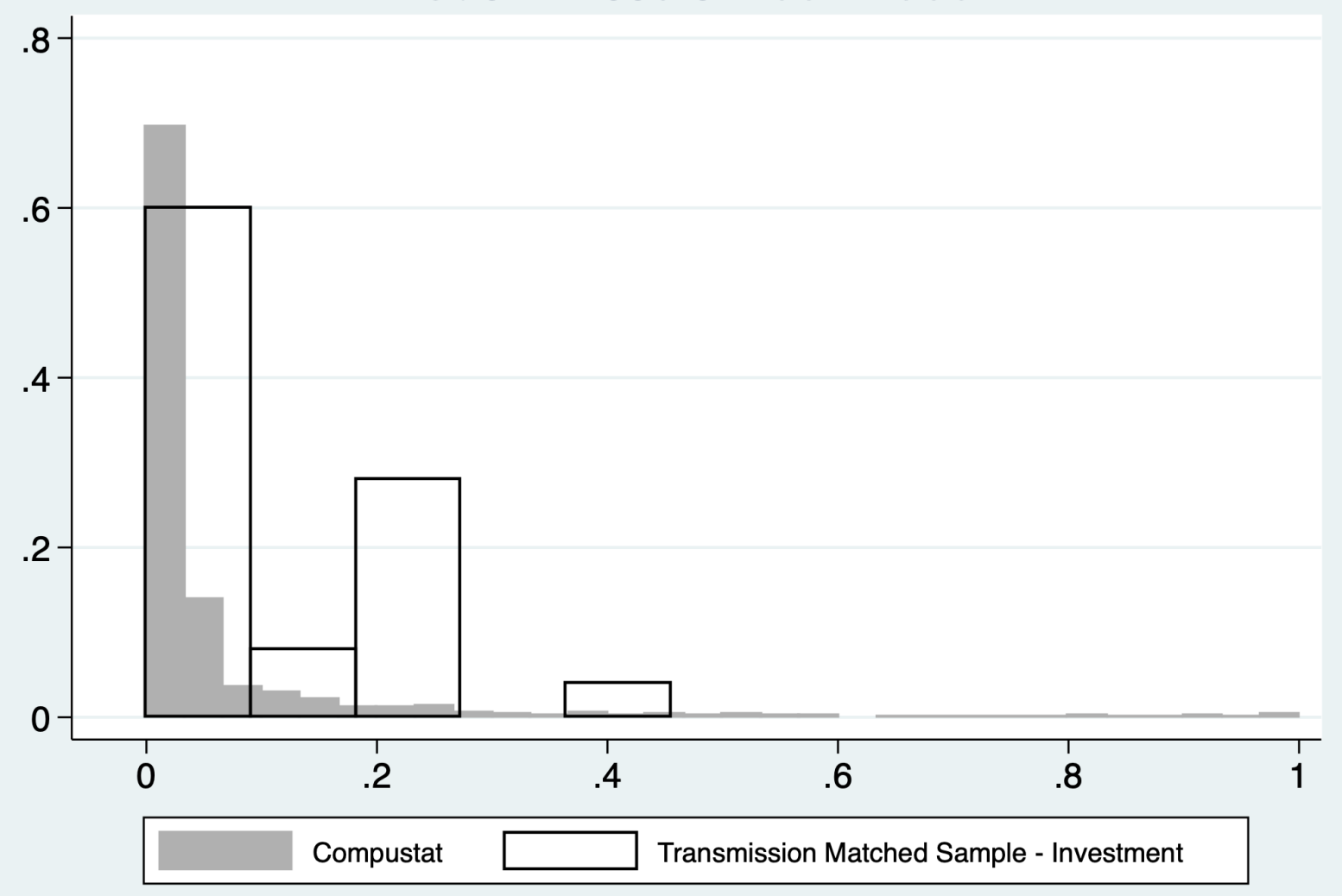


Panel C: Parent Firm Whited-Wu Index - Subsidiary Investment Sample

\section{Whited-Wu Index: 2004-2006}

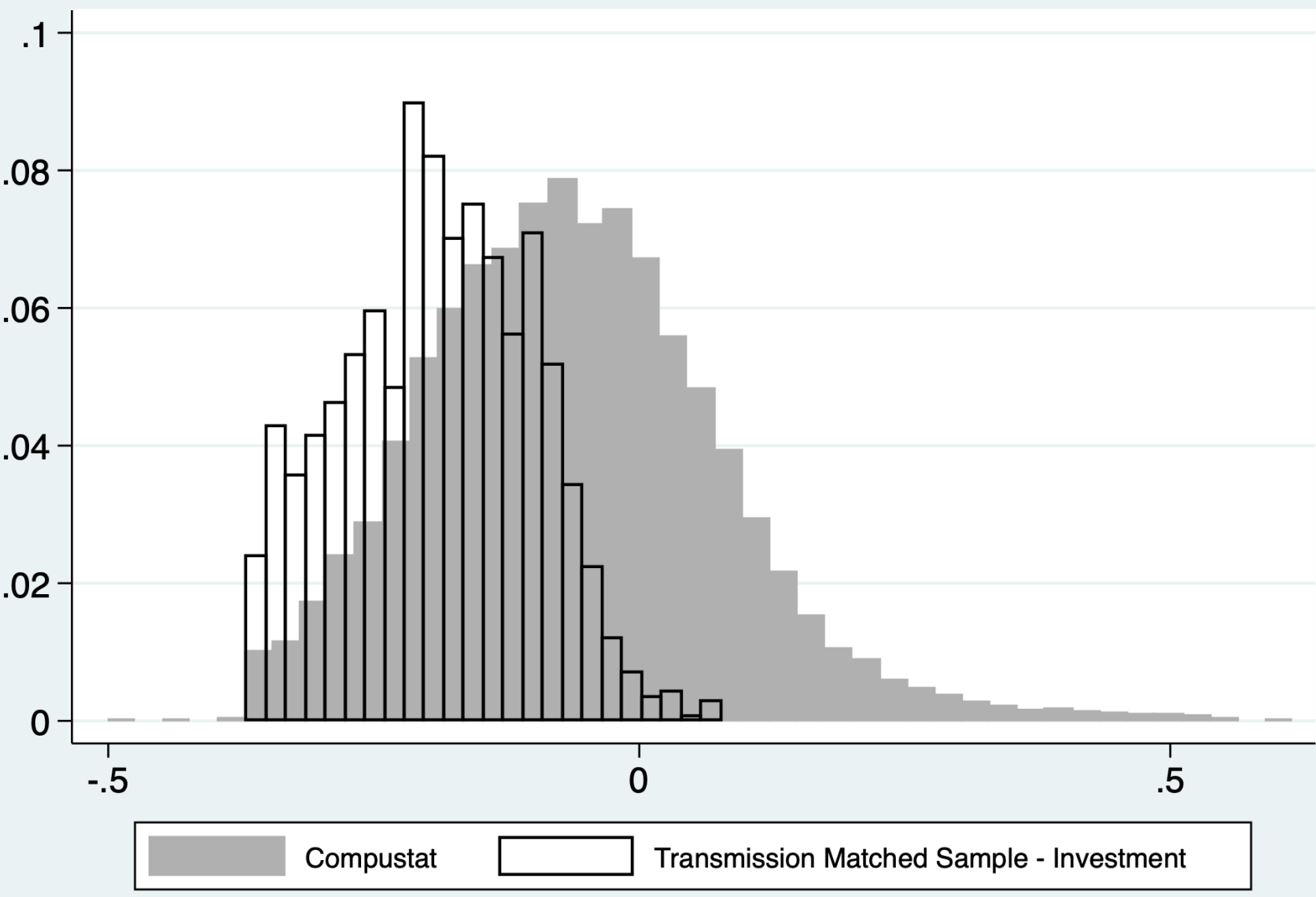


Panel D: Parent Firm Whited-Wu Index - Subsidiary Employment Growth Sample

\section{Whited-Wu Index: 2004-2006}

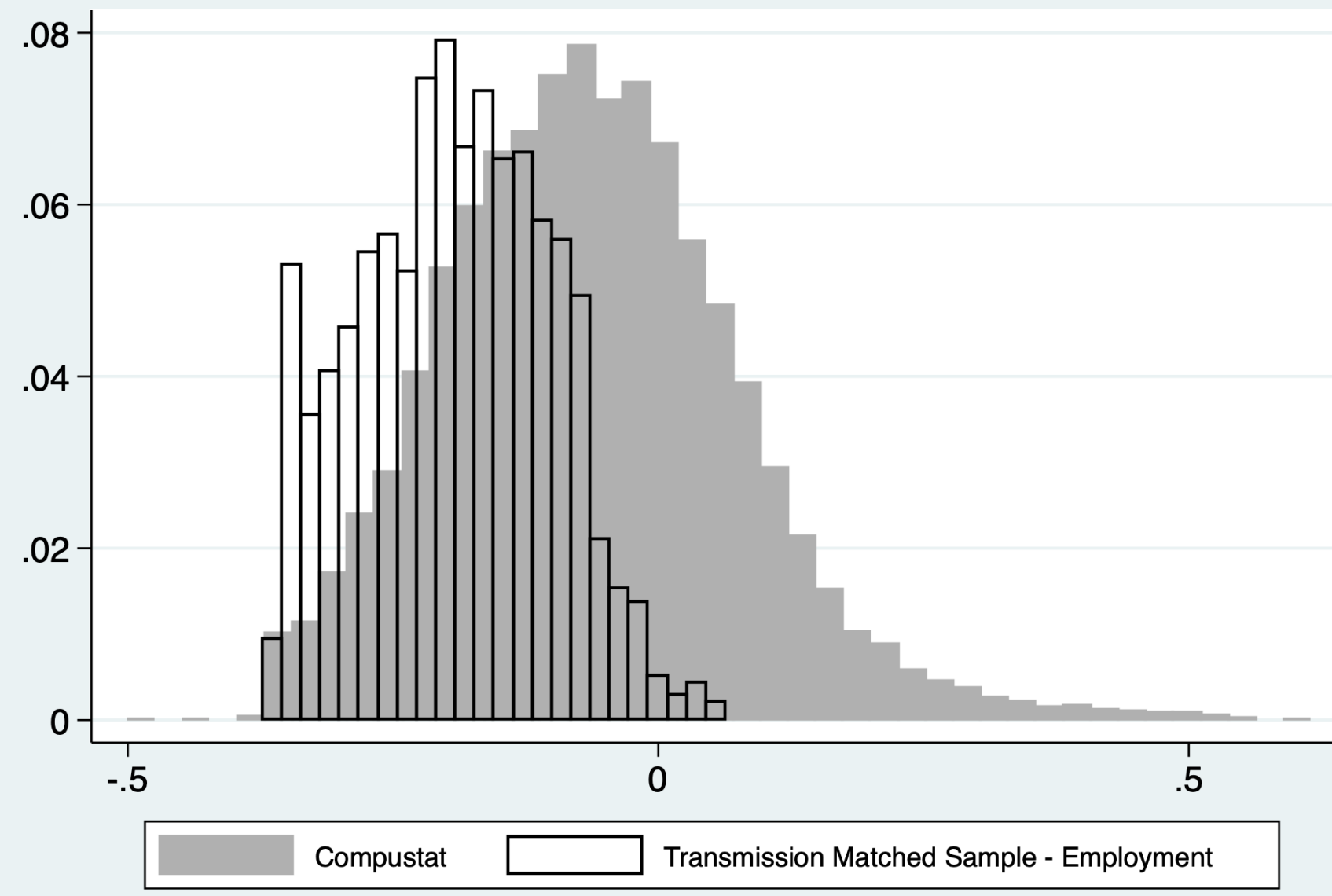

